University of Nebraska - Lincoln

DigitalCommons@University of Nebraska - Lincoln

2010

\title{
A Review of African Blastobasinae (Lepidoptera: Gelechioidea: Coleophoridae), with New Taxa Reared from Native Fruits in Kenya
}

\author{
David Adamski \\ Department of Entomology, National Museum of Natural History, Smithsonian Institution, P.O. Box 37012, \\ MRC 168, Washington, D.C., 20013- 7012, U.S.A., adamskid@si.edu \\ Robert S. Copeland \\ Scott E. Miller \\ Paul D. N. Hebert \\ Karolyn Darrow \\ See next page for additional authors
}

Follow this and additional works at: https://digitalcommons.unl.edu/systentomologyusda

Part of the Entomology Commons

Adamski, David; Copeland, Robert S.; Miller, Scott E.; Hebert, Paul D. N.; Darrow, Karolyn; and Luke, Quentin, "A Review of African Blastobasinae (Lepidoptera: Gelechioidea: Coleophoridae), with New Taxa Reared from Native Fruits in Kenya" (2010). USDA Systematic Entomology Laboratory. 58.

https://digitalcommons.unl.edu/systentomologyusda/58

This Article is brought to you for free and open access by the Entomology Collections, Miscellaneous at DigitalCommons@University of Nebraska - Lincoln. It has been accepted for inclusion in USDA Systematic Entomology Laboratory by an authorized administrator of DigitalCommons@University of Nebraska - Lincoln. 


\section{Authors}

David Adamski, Robert S. Copeland, Scott E. Miller, Paul D. N. Hebert, Karolyn Darrow, and Quentin Luke 


\section{SERIES PUBLICATIONS OF THE SMITHSONIAN INSTITUTION}

Emphasis upon publication as a means of "diffusing knowledge" was expressed by the first Secretary of the Smithsonian. In his formal plan for the Institution, Joseph Henry outlined a program that included the following statement: "It is proposed to publish a series of reports, giving an account of the new discoveries in science, and of the changes made from year to year in all branches of knowledge." This theme of basic research has been adhered to through the years by thousands of titles issued in series publications under the Smithsonian imprint, commencing with Smithsonian Contributions to Knowledge in 1848 and continuing with the following active series:

Smithsonian Contributions to Anthropology

Smithsonian Contributions to Botany

Smithsonian Contributions to History and Technology

Smithsonian Contributions to the Marine Sciences

Smithsonian Contributions to Museum Conservation

Smithsonian Contributions to Paleobiology

Smithsonian Contributions to Zoology

In these series, the Institution publishes small papers and full-scale monographs that report on the research and collections of its various museums and bureaus. The Smithsonian Contributions Series are distributed via mailing lists to libraries, universities, and similar institutions throughout the world.

Manuscripts submitted for series publication are received by the Smithsonian Institution Scholarly Press from authors with direct affiliation with the various Smithsonian museums or bureaus and are subject to peer review and review for compliance with manuscript preparation guidelines. General requirements for manuscript preparation are on the inside back cover of printed volumes. For detailed submissions requirements and to review the "Manuscript Preparation and Style Guide for Authors," visit the Submissions page at www.scholarlypress.si.edu. 


\section{A Review of African Blastobasinae} (Lepidoptera: Gelechioidea: Coleophoridae), with New Taxa Reared from Native Fruits in Kenya

David Adamski, Robert S. Copeland, Scott E. Miller, Paul D. N. Hebert, Karolyn Darrow, and Quentin Luke

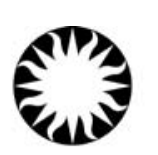

Smithsonian Institution

Scholarly Press

WASHINGTON D.C. 


\begin{abstract}
Adamski, David, Robert S. Copeland, Scott E. Miller, Paul D. N. Hebert, Karolyn Darrow, and Quentin Luke. A Review of African Blastobasinae (Lepidoptera: Gelechioidea: Coleophoridae), with New Taxa Reared from Native Fruits in Kenya. Smithsonian Contributions to Zoology, number 630, vi + 68 pages, 62 figures, 13 maps, 2 tables, 2010. - Twenty-five species of African Blastobasinae (Lepidoptera: Coleophoridae) are reviewed; 12 species are redescribed, and 13 species are described as new. Rearing of Lepidoptera ancillary to sampling efforts targeted for fruit flies (Diptera: Tephritidae) and their parasitoids was conducted in and near forested areas in coastal, central highland, and western highland habitats in Kenya. Reared moths were associated with fruits of 64 plant species in 34 families. Two new species, Blastobasis millicentae and Neoblastobasis perisella, were discovered in mixed original type series of species described by Meyrick and also reared from fruit. Eight new species, Blastobasis acirfa, B. aynekiella, B. chuka, B. elgonae, B. kenya, B. glauconotata, and Neoblastobasis ximeniaella, and N. wangithiae, are known only from specimens reared from fruit. One new species, Blastobasis catappaella, was reared from fruit and collected at black light. Finally, two new species, Neoblastobasis laikipiae and Blastobasis mpala, are known only from black light samples. DNA barcodes augmented the ability to discriminate between some closely related species within several genera. Male specimens of Blastobasis kenya, B. acirfa, and B. aynekiella and some associated female conspecifics, in particular, had distinctly different barcodes but were not initially diagnosed using standard morphological features. Subsequently, corroborative morphological features were found to support the DNA barcode data, and both data are discussed herein. Lectotypes are designated for Blastobasis arguta Meyrick, 1918; B. byrsodepta Meyrick, 1913; B. egens Meyrick, 1918; B. eridryas Meyrick, 1932; B. extensa Meyrick, 1918; B. indigesta Meyrick, 1931; B. industria Meyrick, 1913; and B. trachilista Meyrick, 1921. Zenodochium arguta Meyrick, 1918 is transferred to Calosima Dietz, 1910, new combination, and Tecmerium irroratella Walsingham, 1891 and Blastobasis extensa Meyrick, 1918 are transferred to Holcocera Clemens, 1863, new combinations. Neoblastobasis indigesta (Meyrick, 1931), revised status, is transferred to Blastobasis Zeller, 1855. Syndroma Meyrick is a junior synonym of Holcocera Clemens, 1863, and Syndroma lignyodes Meyrick, 1914 is transferred to Holcocera, new combination. The first African records for Holcocera, Calosima, and Neoblastobasis are reported. A key for all African Blastobasinae is included, together with photographs of the adults and illustrations of the male and female genitalia. Distribution maps are provided for all new species reared from fruits. All taxonomic decisions such as new species, lectotype designations, synonymies, and transfers are attributed to the senior author.
\end{abstract}

Keywords: Lepidoptera, Blastobasis, Calosima, Holcocera, Neoblastobasis, Africa, fruit, DNA barcodes, cytochrome c oxidase I mitochondrial gene.

Cover images, from left to right: photographs of holotypes of Blastobasis glauconotata, B. kenya, and Calosima arguta.

Published by Smithsonian Institution Scholarly Press

P.O. Box 37012, MRC 957

Washington, D.C. 20013-7012

www.scholarlypress.si.edu

Library of Congress Cataloging-in-Publication Data

A review of African Blastobasinae (Lepidoptera:Gelechioidea:Coleophoridae), with new taxa reared from native fruits in Kenya / David Adamski ... [et al.].

p. cm. - (Smithsonian contributions to zoology ; no. 630)

Includes bibliographical references and index.

1. Coleophoridae-Africa-Classification. I. Adamski, David, 1950-

QL561.C58R48 2010

$595.78-\mathrm{dc} 22$

2009048764

ISSN: (print) 0081-0282 / (online) 1943-6696

(6) The paper used in this publication meets the minimum requirements of the American National Standard for Permanence of Paper for Printed Library Materials Z39.48-1992.

This article is a U.S. government work, and is not subject to copyright in the United States. 


\section{Contents}

LIST OF MAPS AND FIGURES v v

INTRODUCTION 1

Acknowledgments 2

MATERIALS AND METHODS 2

RESULTS 3

Key to the Species of Blastobasinae (Coleophoridae) from Africa $\quad 5$

Holcocerini Adamski \& Brown, 1989

Holcocera Clemens, $1863 \quad 6$

Holcocera lignyodes (Meyrick, 1914), new combination 6

Holcocera extensa (Meyrick, 1918), new combination 7

Holcocera irroratella Walsingham, 1891, new combination 7

Calosima Dietz, $1910 \quad 8$

Calosima arguta (Meyrick, 1918), new combination 8

Blastobasini Meyrick, 1894

Neoblastobasis Kuznetzov \& Sinev, 1985

Neoblastobasis laikipiae Adamski, new species 9

Neoblastobasis wangithiae Adamski, new species 11

Neoblastobasis perisella Adamski, new species 11

Neoblastobasis ximeniaella Adamski, new species 14

Blastobasis Zeller, 1855

Blastobasis millicentae Adamski, new species 15

Blastobasis kenya Adamski, new species $\quad \mathbf{1 7}$

Blastobasis acirfa Adamski, new species $\quad 20$

Blastobasis aynekiella Adamski, new species 23

Blastobasis catappaella Adamski, new species 25

Blastobasis glauconotata Adamski, new species 25

Blastobasis chuka Adamski, new species 29

Blastobasis elgonae Adamski, new species 31

Blastobasis indigesta Meyrick, 1931, revised status 33

Blastobasis eridryas Meyrick, 1932 
Blastobasis mpala Adamski, new species

Blastobasis egens Meyrick, 1918

Blastobasis fatigata Meyrick, 1914

Blastobasis taricheuta Meyrick, 1909

Blastobasis trachilista Meyrick, 1921

Blastobasis determinata Meyrick, 1921

Blastobasis byrsodepta Meyrick, 1913

Blastobasis industria Meyrick, 1913

DISCUSSION

Host Plant Distribution of Reared Blastobasinae

Geographical Distribution of Reared Blastobasinae

FIGURES 2-62

REFERENCES

INDEX OF INSECT NAMES 


\section{Maps and Figures}

Map 1. Distribution of Neoblastobasis laikipiae 10

Map 2. Distribution of Neoblastobasis wangithiae 12

Map 3. Distribution of Neoblastobasis perisella 13

Map 4. Distribution of Neoblastobasis ximeniaella 15

Map 5. Distribution of Blastobasis millicentae 16

Map 6. Distribution of Blastobasis kenya 19

Map 7. Distribution of Blastobasis acirfa $\quad 22$

Map 8. Distribution of Blastobasis aynekiella 24

Map 9. Distribution of Blastobasis catappaella 26

Map 10. Distribution of Blastobasis glauconotata 28

Map 11. Distribution of Blastobasis chuka 30

Map 12. Distribution of Blastobasis elgonae 32

Map 13. Distribution of Blastobasis mpala 35

Figure 1. A compressed subtree sequence data of Blastobasinae (Coleophoridae)

Figures 2-4. Male genitalia of Calosima arguta, Neoblastobasis laikipiae, and N. wangithiae

Figures 5-7. Male genitalia of Neoblastobasis perisella,

N. ximeniaella, and Blastobasis fatigata

Figures 8-10. Male genitalia of Blastobasis indigesta, B. millicentae, and B. kenya

Figures 11-13. Male genitalia of Blastobasis acirfa, B. aynekiella, and B. catappaella

Figures 14-16. Male genitalia of Blastobasis glauconotata, B. elgonae, and B. chuka

Figures 17-19. Male genitalia of Blastobasis mpala, B. eridryas, and B. egens

Figures 20-23. Female genitalia of Calosima arguta, Neoblastobasis perisella, N. ximeniaella, and Holcocera extensa

Figures 24-27. Female genitalia of Blastobasis egens, B. trachilista, B. taricheuta, and B. kenya 
Figures 28-30. Female genitalia of Blastobasis acirfa, B. aynekiella, and $B$. determinata

Figures 31-34. Female genitalia of Blastobasis glauconotata, $B$. industria, Holcocera irroratella, and B. byrsodepta

Figures 35-37. Female genitalia of Blastobasis catappaella, B. chuka, and B. mpala

Figures 38-49. Adults of Blastobasis millicentae, B. industria,

$B$. eridryas, B. determinata, Holcocera extensa, B. indigesta, B. chuka, B. egens, B. glauconotata, B. byrsodepta, $H$. irroratella, and B. elgonae

Figures 50-58. Adults of Blastobasis taricheuta, Calosima arguta, B. trachilista, Neoblastobasis ximeniaella, N. wangithiae, B. mpala, B. aynekiella, B. acirfa, and N. laikipiae

Figures 59-62. Adults of Blastobasis catappaella, B. kenya, B. fatigata, and Neoblastobasis perisella 


\section{A Review of African Blastobasinae (Lepidoptera: Gelechioidea: Coleophoridae), with New Taxa Reared from Native Fruits in Kenya}

David Adamski, Department of Entomology, National Museum of Natural History, P.O. Box 37012, NHB - E523, Smithsonian Institution, Washington, D.C. 20013-7012, USA; Robert S. Copeland, Department of Entomology, Texas A\&M University, College Station, Texas 77843, USA, and International Centre of Insect Physiology and Ecology, Box 30772, Nairobi 00100, Kenya; Scott E. Miller and Karolyn Darrow, Department of Entomology, National Museum of Natural History, Smithsonian Institution, Washington, D.C. 20013-7012, USA; Paul D. N. Hebert, Department of Integrative Biology, University of Guelph, Guelph, Ontario N1G 2W1, Canada; Quentin Luke, East African Herbarium, National Museums of Kenya, Box 45166, Nairobi, Kenya. Correspondence: D. Adamski, adamskid@si.edu. Manuscript received 19 December 2008; accepted 14 July 2009.

\section{INTRODUCTION}

Collaboration among the International Centre of Insect Physiology and Ecology (ICIPE), the Smithsonian Institution's National Museum of Natural History (USNM), the National Museums of Kenya (NMK), and the Department of Integrative Biology, University of Guelph, in understanding the Lepidoptera of Kenya has provided an opportunity to review the Blastobasinae (Coleophoridae) of Africa. From 1999 to 2004, Copeland directed an insect-rearing program from native fruit at sampling sites throughout Kenya. Much of the data from this study, which focused primarily on fruit flies (Tephritidae), has been published elsewhere (Copeland et al., 2002, 2004, 2005, 2006; De Meyer et al., 2002; White et al., 2003; Barr et al., 2006; Copeland and Wharton, 2006; De Meyer and Freidberg, 2006). Additionally, this study has provided the largest sample of reared Blastobasinae known from the African continent.

From 1998 to 2006, Miller (Miller, 2000) intensively sampled moths with black light at Mpala Research Centre (MRC) in central Kenya, thus providing a long-term view of the Blastobasinae at a single site. In order to provide a context for these samples, we examined the type material of all the previously described species of Blastobasinae from Africa. We used classical morphological characters and DNA barcodes (Hebert et al., 2003; Burns et al., 2007, 2008) to assess species limits. Although we are still accumulating samples of Blastobasinae from additional African localities, we are publishing this paper now to provide a taxonomic framework for further studies and to make the fruit-rearing data available for further analysis.

In the modern keys to moth families in Africa, only Delvare and Aberlenc (1989) and Holloway et al. (1987) included Blastobasinae; Janse (1932-1964), Pinhey (1975), and Scholtz and Holm (1985) did not. We follow Hodges (1998), who treated Blastobasidae sensu Meyrick (1894) as one of four subfamilies 
within Coleophoridae. Both Hodges (1998) and Adamski and Brown (1989) agree on the monophyly of the Blastobasinae. These small- to medium-sized moths can be identified by the following combination of characters: forewing with pterostigma between $\mathrm{Sc}$ and $\mathrm{R}_{1}$, base of $\mathrm{CuA}_{2}$ at or near right angle to cubitus, subcubital retinaculum present in female, spiniform setae on abdominal terga, aedeagal sclerite present, valva divided, and anellus setose.

\section{ACKNOWLEDGMENTS}

We thank Kuniko Arakawa, Mizukino, Moriya-shi, Japan, and José Alejandro Herrera, San José, Costa Rica, for the illustrations of the genitalia; Lauren Helgen, Department of Entomology, Smithsonian Institution, for assistance with finishing the manuscript, including Figure 1; and Dan G. Cole, National Museum of Natural History, Smithsonian Institution, for the production of the distribution maps. We thank Kevin Tuck, Natural History Museum, London; Barbara Dombrowsky, Transvaal Museum, Pretoria, South Africa; and Margie Cochrane, South African Museum, Cape Town, South Africa, for the loan of type specimens. Funding was provided through collaboration between the International Centre of Insect Physiology and Ecology and the Smithsonian Institution, in cooperation with the National Museums of Kenya. We thank Richard Bagine, Kenya Wildlife Service, for permission to sample wild fruits.

This work was supported by USAID grant PCE-G-0098-0048-00 (in collaboration with the International Centre of Insect Physiology and Ecology and its African Fruit Fly Initiative) and in part by USDA/CSREES/IFAFS grant 00-52103-9651, both awarded to R. A. Wharton, Texas A\&M University.

\section{MATERIALS AND METHODS}

This study is based on approximately 300 specimens, including primary types of all named species, over 250 genitalic dissections, and 169 cytochrome c oxidase I (COI) sequences.

As part of biodiversity inventories undertaken in collaboration among MRC, ICIPE, USNM, and NMK (Miller, 2000; Miller and Lazell, 2003; Miller and Rogo, 2003), moths were collected at MRC by Scott Miller and Tina Kuklenski on 24 nights from May 1998 to December 1999 and on an additional 8 nights from 2000 through 2003. Moths were collected at mercury vapor and florescent black lights. The microlepidoptera were individually killed and spread in the field.

The MRC is a biological field station managed in collaboration with Kenya Wildlife Service, NMK, Princeton University, and the Smithsonian Institution. It is located in semiarid savanna on the Laikipia Plateau of central Kenya, west of Mount Kenya, $50 \mathrm{~km}$ north of the equator, and 50 $\mathrm{km}$ from Nanyuki town. MRC is at $1650 \mathrm{~m}$ elevation at $0.293^{\circ} \mathrm{N}$ and $36.899^{\circ} \mathrm{E}$. Young et al. $(1995,1997)$, Keesing (1998, 2000), and the Mpala Wildlife Foundation (http:// www.mpala.org) provide general descriptions of the environment. Annual mean rainfall at MRC is between 550 and $660 \mathrm{~mm}$, but with substantial spatial and temporal heterogeneity (Berger, 1989). The vegetation is characteristic of semiarid African savannas, predominantly grassy savanna bushland, with patches of woodland and open grassland. Dominant trees include Acacia (Mimosaceae), Balanites (Balanitaceae), and Boscia (Capparaceae).

Although MRC has excellent facilities and is well situated in one of the most biologically interesting regions of Kenya, little invertebrate inventory work has been conducted there. Moreover, the Laikipia area has historically been ignored both by visiting biological expeditions and by local Kenyan residents, in part because it is outside of the famous wildlife parks. Early expeditions collected some insects in the Laikipia area, but they collected very few moths (e.g., von Höhnel, 1894; Chanler, 1896; Gregory, 1896; Rehn, 1936). On a purely historical note of interest, a nearby ranch was featured in the recent movie I Dreamed of Africa, based on the book by Kuki Gallmann (1991), and the natural history of another adjacent ranch has been recorded elegantly in popular essays by Grant $(1995,2001)$.

Rearing methods and sampling strategy for the native fruit-rearing program are provided by Copeland et al. (2002) and Copeland (2006). All fruits were collected from native plant species except for Passiflora mollissima (Kunth) L. H. Bailey (Passifloraceae). Ripe and unripe fruits were collected from plants and occasionally from the ground; samples showing noticeable rotting were discarded. Because of the rearing conditions and multiple techniques involved, the quality of adult moths varied. Thus, some specimens were not used in the analysis because of their poor condition.

The color standard for the description of the adult vestiture is from Kornerup and Wanscher (1978). Genitalia were dissected as described by Clarke (1941), except Mercurochrome and chlorazol black were used as stains. Pinned specimens and genital preparations were examined with dissecting and compound microscopes. 
All descriptions and redescriptions are based on adult morphology. The descriptions of the male and female genitalia, with respect to the orientation of a structure or structures relative to each other, were made as they are observed on the body proper and not how they may be illustrated from a permanent slide preparation. Measurements of wings were made using a calibrated ocular micrometer. Label data are given verbatim within quotations for all primary types and for selected paratypes. Other label data for reared specimens having "R.S. Copeland," "ICIPE/ USAID," and "Restrictions Apply, NMK/ICIPE, Agreement \# 5," and the prefix of all eight-digit barcodes are omitted from the text. Genitalia slide numbers are in D. Adamski series unless noted otherwise. Acronyms for the depositories of specimens examined are as follows.

BMNH Natural History Museum, London, UK

NMK National Museums of Kenya, Nairobi, Kenya

MRAC Royal Museum of Central Africa, Tervuren, Belgium

SAMC South African Museum, Cape Town, South Africa

TMP Transvaal Museum, Pretoria, South Africa

USNM National Museum of Natural History, Smithsonian Institution, Washington, D.C., USA

All new species are attributed to the senior author.

Sequences were produced at the University of Guelph.

DNA was extracted from legs of adult specimens and amplified using a QIAGEN DNeasy Tissue Kit. Primers LepF1 and LepR1 (Hebert et al., 2004) were used to obtain a 658 base pair fragment of COI with a standard thermocycling regime (Hajibabaei et al., 2006). PCR products were sequenced subsequently on an ABI 3730 capillary sequencer. Sequences are available at the National Center for Biotechnology Information GenBank database (accession numbers GQ330121-GQ330289) and at the Barcode of Life Database (BOLD). Neighbor-joining (NJ) trees were generated from nucleotide sequences as implemented in BOLD (Ratnasingham and Hebert, 2007). Phylogenetic and molecular evolutionary analyses were conducted using Molecular Evolutionary Genetics Analysis (MEGA) version 4 (Tamura et al., 2007). While we recognize the limitations of $\mathrm{NJ}$ trees, they are an efficient means of analyzing and presenting DNA barcode data (Hajibabaei et al., 2006, 2007; DeSalle, 2007; Waugh et al., 2008). Our initial species identifications were based on morphology and were then tested against clustering based on DNA. We rechecked morphology when there were inconsistencies. DNA was especially helpful in associating conspecific males and females, as well as revealing some initial errors in morphological identifications. In only three cases (see "DNA Sequence Data" in "Discussion") did morphology and DNA not agree on species identification, likely because of contamination. Because we expect to add DNA sequences for many species in the future, we are delaying more detailed analysis of sequences.

In this study, we regard all specimens within a type series that contains two or more specimens of a species described by E. Meyrick as syntypes. Although Meyrick indicated to Janse (in personal correspondence) in October 1909 and July 1912 that he considered the specimens studied and returned to Transvaal as "types" (see Janse, 1968), Meyrick did not specify a "type" in his original descriptions. Therefore, the "gentleman's agreement" between Meyrick and Janse is not binding under the International Code of Zoological Nomenclature (ICZN), and it is our opinion that Janse erroneously labeled such specimens as "holotype." Gozmány and Váry (1973) support this view, citing ICZN article 73(b), and they further indicate that Janse's "holotype" designations are actually "lectotype" selections. We do not agree with Gozmány and Váry's conclusion about "lectotype" selections by Janse, but we believe that their decision originated from their belief that all specimens within a type series that contains two or more specimens of a species described by E. Meyrick were indeed syntypes. If this is true, then their view supports our argument. We thus treat all specimens within Meyrick's type series as having equal status, and our "lectotype" designations are based on the quality of the specimens rather than present deposition.

\section{RESULTS}

The taxon tree or phenogram (Figure 1) represents a total of 169 sequence samples for 15 species of Blastobasinae (Coleophoridae) reared from fruit or collected at black light in Kenya. Sequence data for Blastobasis kenya are represented by 57 samples and 1 "outlier" sequence of Blastobasis chuka (ô: 00196357, DA 5093).

Blastobasis elgonae is represented by two sequences (ô: 00196891, DA 5020 and $9: 00196892$, DA 5021) that cluster with one sample of B. glauconotata (OA: 00196387 , DA 5019) and near one sample of B. glauconotata ( $\delta^{\lambda}$ : 00196367, DA 5106). Species assignments for these samples are resolved by examination of the male genitalia.

Four specimens from Shimba Hills diverge from the main Blastobasis acirfa cluster. Three of these ( ${ }^{\top}: 00196314$, 


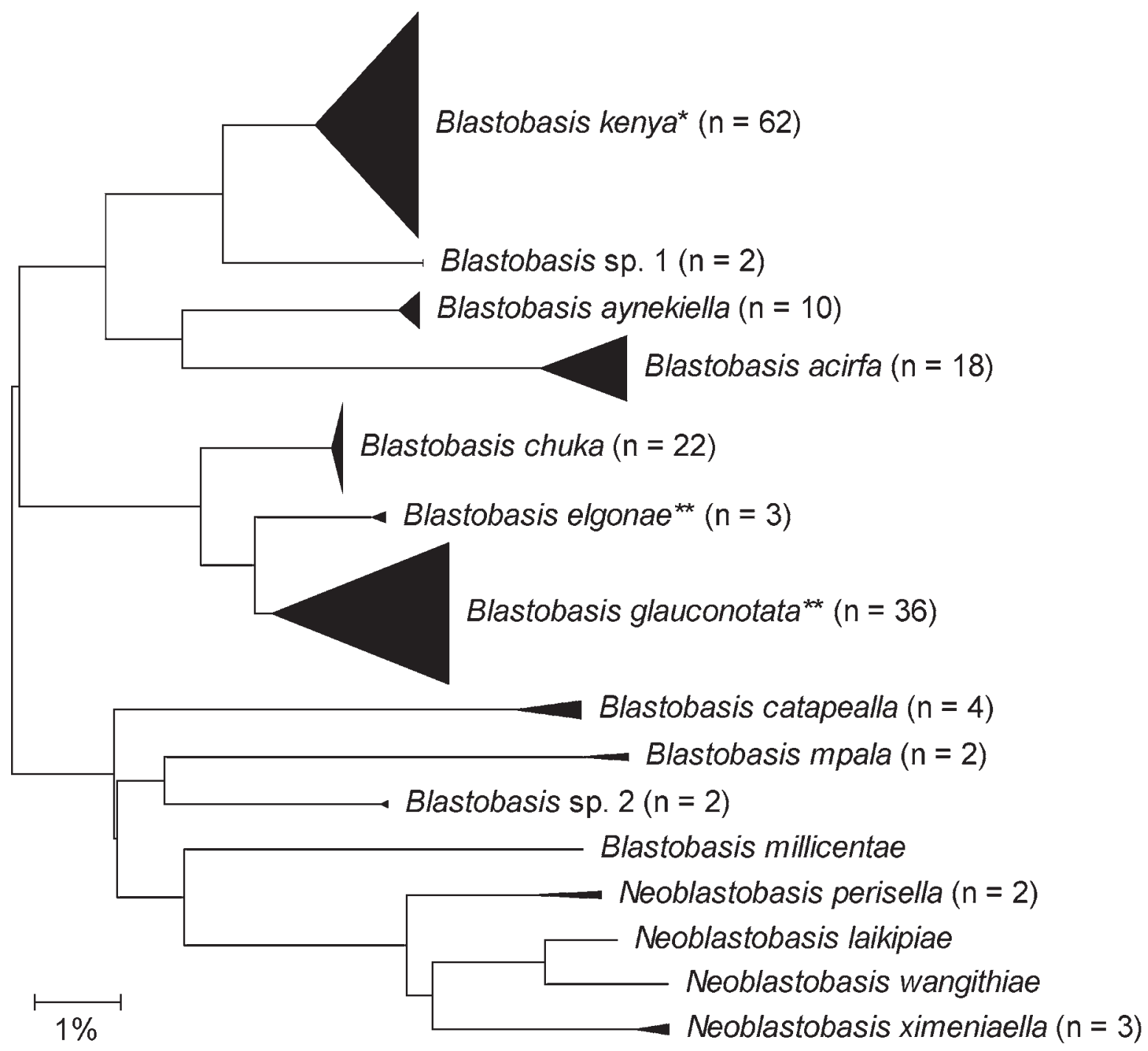

FIGURE 1. A compressed subtree sequence data of Blastobasinae (Coleophoridae) taken from 169 samples among 15 species from Kenya based upon neighbor-joining analysis with Kimura 2-parameter model using pairwise deletion of gaps and or missing data. The analysis shows that 168 of the 659 sites exhibited variability. Subtrees are compressed into triangles with a vertical scale of 2 pixels per specimen; the horizontal scale corresponds to divergence. A single asterisk (") indicates a sample of Blastobasis kenya with one "outlier" sample (USNM 00196357); $\because *$ indicates two “outlier” samples of Blastobasis glauconotata (USNM 00196387 and 00196367$).$

DA 5062; + : 00196381, DA 5121; + : 00196410) may represent an undescribed species, but we do not treat this in the taxonomic section because their identities are not clear because of the poor condition of the specimens. The fourth specimen in the divergent cluster (o: 00196356, DA 5092) is identified as Blastobasis chuka and is treated below.
Two divergent samples ( $\circ$ : 00196429 and $\circ$ : 00196430) near Blastobasis kenya are treated as unassociated females and are not included in the taxonomic part of the text. Similarly, two divergent samples (o: 00196893, DA 4361 and o: 00196405) near Blastobasis mpala are treated as unassociated females. 


\section{KEY TO THE SPECIES OF BLASTOBASINAE (COLEOPHORIDAE) FROM AFRICA}

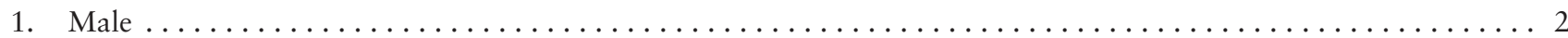

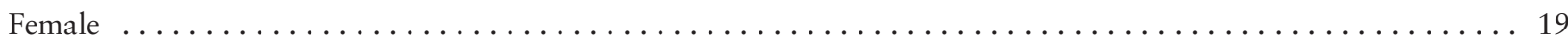

2. Juxta platelike; dorsoposterior margin of gnathos entire; Holcocerini [Figure 2] . . . . . . . . . . Calosima arguta Juxta bandlike or divided; dorsoposterior margin of gnathos medially bidentate; Blastobasini [Figures 3-19] . . . . . 3

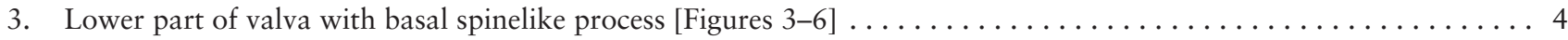

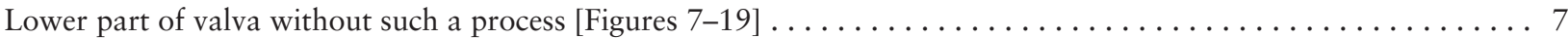

4. Basal spinelike process extending less than or half length of lower part of valva $[$ Figures $3-4] \ldots \ldots \ldots$

Basal spinelike process extending more than half length of lower part of valva [Figures $5-6] \ldots \ldots \ldots$

5. First flagellomere of the antenna unmodified; anellus of aedeagus bilobed apically [Figure 3] . . . . Neoblastobasis laikipiae First flagellomere of the antenna notched; anellus of aedeagus broadly rounded apically [Figure 4$] \ldots \ldots \ldots . . . . .$. $\ldots \ldots \ldots \ldots \ldots \ldots \ldots \ldots \ldots \ldots \ldots \ldots \ldots \ldots \ldots \ldots \ldots \ldots \ldots$ Neoblastobangithiae

6. Basal spinelike process extending to apicoventral margin of lower part of valva [Figure 6]... . Neoblastobasis ximeniaella Basal spinelike process extending beyond apicoventral margin of lower part [Figure 5] . . . . Neoblastobasis perisella

7. Juxta divided; valva bearing a large spinelike seta or a cluster of several elongate spinelike setae [Figures 7, 9] . . . . 8 8 Juxta not divided; valva not bearing a large spinelike seta or a cluster of several large spinelike setae [Figures 8, 10-19]

8. Base of digitate process of upper part of valve bearing one elongate spinelike seta; base of digitate process of upper part of valva without spinelike setae $[$ Figure 9$] \ldots \ldots \ldots \ldots \ldots \ldots \ldots \ldots \ldots \ldots \ldots$. $\ldots \ldots \ldots$. $\ldots \ldots$ millicentae Base of digitate process of upper part of valva bearing a cluster of several spinelike setae [Figure 7]. . . Blastobasis fatigata

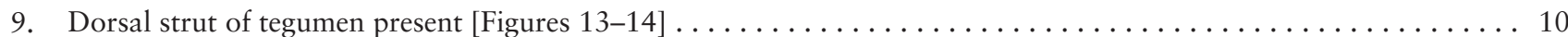

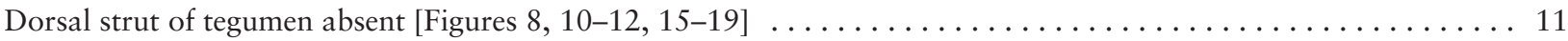

10. Basiventral margin of proximal flange emarginate $[$ Figure 13$] \ldots \ldots \ldots \ldots$. . . . . . . Blastobasis catappaella Basiventral margin of proximal flange broadly rounded $[$ Figure 14$] \ldots \ldots$. . . . . . . . Blastobasis glauconotata

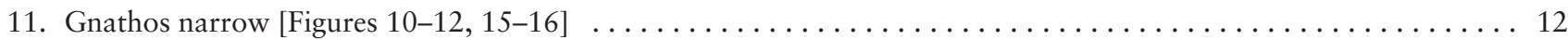

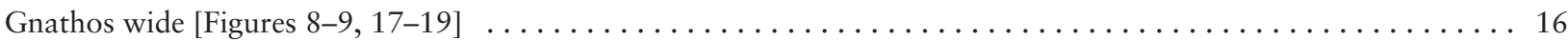

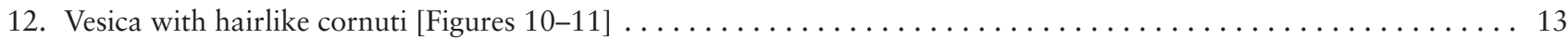

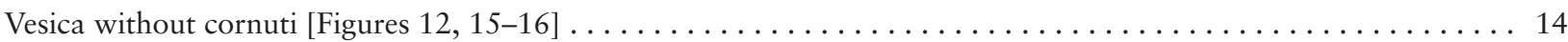

13. Dorsoposterior margin of gnathos widely bidentate medially $[$ Figure 11$] \ldots \ldots \ldots$. . . . . . . . Blastobasis acirfa Dorsoposterior margin of gnathos narrowly bidentate medially [Figure 10] . . . . . . . . . . . Blastobasis kenya

14. Apicoventral margin of lower part of valva broadly rounded [Figure 15] . . . . . . . . . . . . Blastobasis elgonae Apicoventral margin of lower part of valva short and angular $[$ Figures 12,16$] \ldots \ldots \ldots$

15. Dorsoposterior margin of gnathos near level of base of uncus; aedeagus acutely curved near apical 1/3 [Figure 16] .... . Dorsoposterior margin of gnathos anterior to level of uncus; aedeagus serpentine shaped [Figure 12]

Blastobasis chuka $\ldots \ldots \ldots \ldots \ldots \ldots \ldots \ldots \ldots \ldots \ldots \ldots \ldots \ldots \ldots \ldots \ldots \ldots \ldots \ldots \ldots \ldots \ldots \ldots \ldots \ldots$.astobas aynekiella

16. Uncus broadly rounded apically; aedeagus straight or nearly so $[$ Figures 17,19$] \ldots \ldots \ldots$ Uncus narrowly rounded apically; aedeagus broadly curved $[$ Figures 8,18$] \ldots \ldots \ldots$

17. Dorsoposterior margin of gnathos protuberant medially; anellus of aedeagus wide thorough length [Figure 17] ....... .

Blastobasis mpala Dorsoposterior margin of gnathos not protuberant; anellus of aedeagus gradually narrowed from base [Figure 19] ....

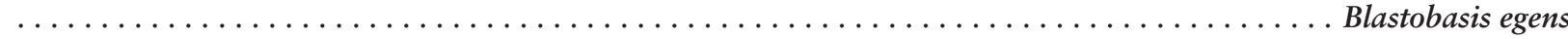

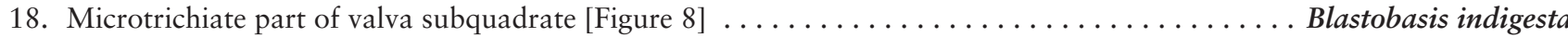
Microtrichiate part of valva elongate, narrowed distally $[$ Figure 18$] \ldots \ldots \ldots \ldots$. . . . . . Blastobasis eridryas

19. Ostium near anterior end of eighth sternum [Figures $20,23,33]$, Holcocerini $\ldots \ldots \ldots \ldots$ Ostium near posterior end of seventh sternum [Figures 21-22, 24-32, 34-37], Blastobasini . . . . . . . . 22

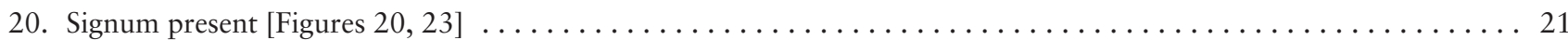
Signum absent [Figure 33]

Holcocera irroratella 
21. Inception of ductus seminalis posterior to posterior margin of seventh sternum [Figure 20] . . . . . . Calosima arguta Inception of ductus seminalis anterior to posterior margin of seventh sternum [Figure 23] . . . . . . Holcocera extensa

22. Ductus bursae not extending beyond posterior margin of sixth segment; ductus bursae, without internal imbricate platelets or spinules $[$ Figure 24$] \ldots \ldots \ldots \ldots \ldots \ldots \ldots \ldots \ldots \ldots \ldots \ldots \ldots$ egens Ductus bursae extending beyond anterior margin of sixth segment, with internal imbricate platelets or spinules in anterior

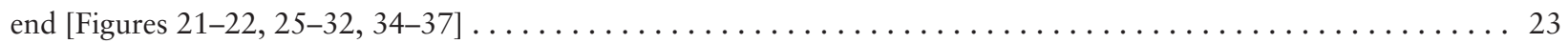

23. Seventh tergum with stout, spinelike setae $[$ Figures $21-22,29-30,34] \ldots \ldots \ldots \ldots$ Seventh tergum without stout, spinelike setae [Figures $25-28,31-32,35-37] \ldots \ldots \ldots$

24. Paired lobelike invaginations posterolateral to ostium $[$ Figure 22] . . . . . . . . . Neoblastobasis ximeniaella

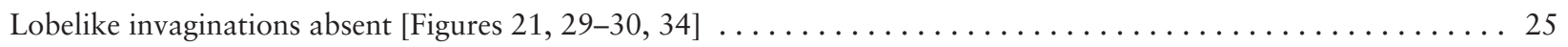

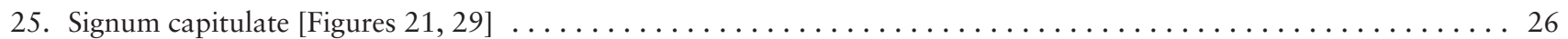

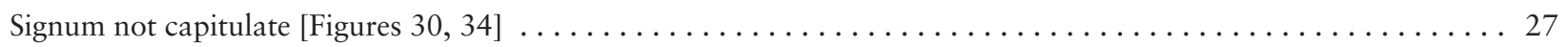

26. Membrane lateral to ostium densely microtrichiate [Figure 29] . . . . . . . . . . . . Blastobasis aynekiella Membrane lateral to ostium without microtrichiae $[$ Figure 21$] \ldots \ldots \ldots \ldots$. . . . . . . Neoblastobasis perisella

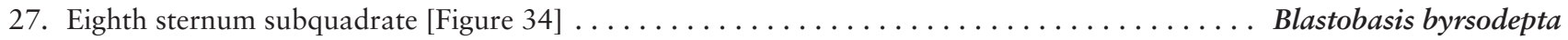

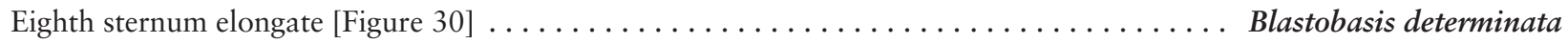

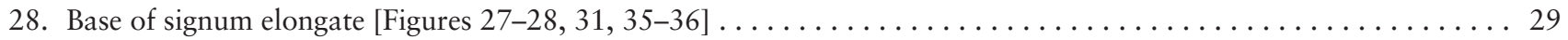

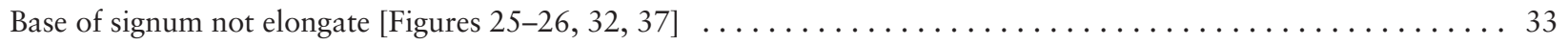

29. Membrane adjacent to ostium densely microtrichiate $[$ Figures $27,31,36] \ldots \ldots \ldots$ Membrane adjacent to ostium sparsely microtrichiate $[$ Figures 28,35$] \ldots \ldots \ldots \ldots$

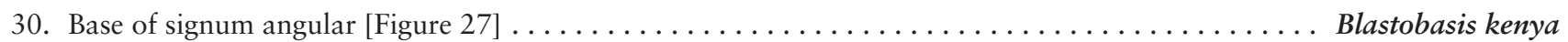

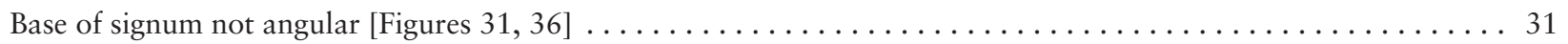

31. Ductus bursae longer than ovipositor $[$ Figure 36$] \ldots \ldots \ldots \ldots \ldots \ldots$. . . . . . . . . . Blastobasis chuka Ductus bursae about $2 / 3$ length of ovipositor [Figure 31$] \ldots \ldots \ldots \ldots$. . . . . . . Blastobasis glauconotata

32. Spinelike process of signum arising from middle of funnel-shaped base [Figure 28$] \ldots \ldots$. . . . . . Blastobasis acirfa Spinelike process of signum originating asymmetrically from base [Figure 35$] \ldots \ldots \ldots$. . . Blastobasis catappaella

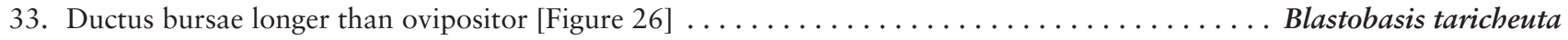
Ductus bursae shorter than or as long as ovipositor [Figures $25,32,37] \ldots \ldots \ldots \ldots$

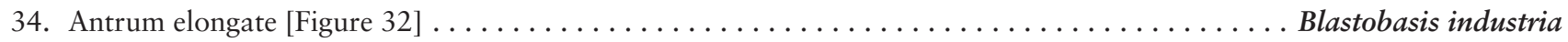

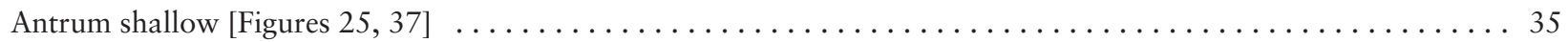

35. Ductus bursae about as long as ovipositor [Figure 37$] \ldots \ldots \ldots \ldots \ldots \ldots$. . . . . . . . . Blastobasis mpala Ductus bursae shorter than ovipositor [Figure 25]

Blastobasis trachilista

\section{Holcocerini Adamski \& Brown, 1989}

Holcocerini are the best-known blastobasine moths in the New World. This is likely because the tribe contains the largest species within the subfamily. Although the tribe contains over 160 described species, host associations for fewer than $13 \%$ of the total species are known. The Holcocerini can be distinguished by the following apomorphies: male aedeagus with a ring support at base and female having a telescopic ovipositor with three membranous subdivisions posterior to eighth segment, eighth sternum with anterior margin emarginated medially, ostium near anterior end of eighth sternum, and inception of ductus seminalis distant from ostium. In addition, there are several plesiomorphies found in most species of Holcocerini listed by Adamski and Brown (1989) that are helpful in differentiating them from species of Blastobasini.

\section{Holcocera Clemens, 1863}

Type Species. Holcocera chalcofrontella Clemens, 1863, by subsequent designation (Walsingham, 1907).

The genus contains more species than all other genera within the Holcocerini worldwide. However, this disparity may be a result of disproportionate sampling. This genus is recognized by having a gnathos with the ventrolateral margin weakly fused with the tegumen, anellus multisetose, and a valva with the proximal flange not overlaid by microtrichiate membrane or sclerotized integumen.

\section{Holcocera lignyodes (Meyrick, 1914), new combination}

Syndroma lignyodes Meyrick, 1914b:271, type species of Syndroma Meyrick, 1914b. New synonym. 
Syndroma lignyodes Meyrick, 1914b:271.—Clarke, 1963: 497.

Holotype. $\hat{\jmath}$, "M[ount] Mlanje, Nyasaland [Malawi], 20.I.1914, S.A. Neave, 1914-SSC"; "Syndroma lignyodes, Meyr., Type M603"; "Genotype, Syndroma Meyrick"; "ठ wing venation on slide 13.V.1949, JFGC 9480" [wing only, abdomen missing] [BMNH].

REMARKs. The presence of a notched first flagellomere of the antenna combined with holcocerine venational characteristics of the holotype justifies synonymy of the genus. The species is not included in the key because the pattern is worn and the abdomen is missing from the holotype.

\section{Holcocera extensa (Meyrick, 1918), new combination}

FIGURES 23, 42

Blastobasis extensa Meyrick, 1918:55.-Sinev, 2004:116.

Diagnosis. Except for Holcocera lignyodes, $H$. extensa and $H$. irroratella are the only two species of Holcocera known from Africa. Although $H$. extensa is slightly larger and darker in appearance than $H$. irroratella, the female genitalia appear more reliable for differentiating the two species. $H$. extensa can be distinguished from $H$. irroratella by having a wider notch on the anterior margin of the eighth sternum, signum present within the corpus bursae, and the anterior part of the ductus bursae spinulate. Relationships of Holcocera extensa and H. irroratella are uncertain because males are not known and female genital characters tend to be conservative in nature throughout Blastobasinae.

\section{REDESCRIPTION.}

Head: Vertex and frontoclypeus with narrow pale gray scales. Outer surface of labial palpus grayish brown or gray intermixed with a few gray scales tipped with pale gray, white scales near subapical area of segment II and basal area of segment III, inner surface paler. Scape of antenna with scales grayish brown tipped with pale gray, flagellum grayish brown, gradually paler to apex. Proboscis with scales grayish brown tipped with pale gray.

Thorax: Tegula and mesonotum gray on anterior and posterior $1 / 3$, pale gray on transverse median $1 / 3$. Legs with scales grayish brown tipped with white with a white band near midfemur and apices of all segments and tarsomeres. Forewing (Figure 42) length 8.2-8.5 mm $(n=2)$, grayish brown intermixed with grayish brown scales tipped with pale gray and pale gray scales; two grayish brown streaks along radius and cubitus of cell; cell with a grayish brown spot on distal end near cubitus. Fringe grayish brown tipped with pale gray. Undersurface grayish brown. Hindwing: Pale grayish brown.

Abdomen: Male genitalia: Unknown. Female genitalia (Figure 23): Eighth sternum trapezoid, deeply emarginate medially on anterior end; antrum cuplike; inception of ductus seminalis on ductus bursae near anterior end of seventh sternum; posterior margin of seventh sternum straight; ductus bursae longer than ovipositor, slightly spiculate internally on anterior $2 / 3$; corpus bursae ovoid, signum spiculate, ovoid.

Leстотуре. Designated herein, 9 , "[South Africa] Pret[oria], North, 12-2 [February]-1912, C.J. Swierstra"; "539"; "ㅇ Genitalia Slide by D. Adamski, No. 4489" [yellow label]; "Blastobasis extensa Meyr., Type No. 2551" [TMP]. A lectotype is designated in order to maintain stability of usage of the name of a taxon with congeners that look similar.

Paralectotype. + , "Pretoria, Transvaal, C.J. S[wierstra] 25-12 [December]-[19]16"; "Blastobasis extensa Meyr[ick], 1/1, E. Meyrick det., in Meyrick Coll[ection]"; "Meyrick Coll[ection], BM 1938-290"; "extensa Meyr[ick]" [abdomen missing] [BMNH].

Remarks. Sinev (2004) treated two syntypes of Blastobasis extensa as blastobasine moths without examining the original type series and without designating a lectotype for the species. Therefore, the identifications for the two specimens that Sinev (2004) provided are unreliable.

\section{Holcocera irroratella Walsingham, 1891, new combination}

FIGURES 33, 48

Blastobasis irroratella Walsingham, 1891:122, pl. VI, fig. 63.-Janse, 1917:192, check list.-Medler, 1980:307, check list.

Tecmerium irroratella: Sinev, 2004:117.

Diagnosis. H. irroratella can be distinguished from $H$. extensa by having a narrower notch on the anterior margin of the eighth sternum, signum absent within the corpus bursae, and the anterior part of the ductus bursae absent of spinules. Relationships of Holcocera irroratella and $H$. extensa are uncertain because males are not known and female genital characters tend to be conservative in nature throughout Blastobasinae. 


\section{REDESCRIPTION.}

Head: Vertex and frontoclypeus white intermixed with a few white scales tipped with brown and a few brown scales. Outer surface of labial palpus brown intermixed with a few white scales and white scales tipped with brown, inner surface white intermixed with a few brown scales; segment II short; scape of antenna white intermixed with a few brown scales, flagellum white. Proboscis white.

Thorax: Tegula and mesonotum white intermixed with white scales tipped with brown and a few brown scales. Legs brown intermixed with white scales tipped with brown, with a white band near midfemur and apices of all segments and tarsomeres. Forewing (Figure 48) length 6.6 $\mathrm{mm}(n=1)$, white intermixed with white scales tipped with brown and some brown scales; median fascia and marginal spots absent; three distinct markings; brown streak near midcell, brown spot posterior midcell streak in area between $\mathrm{CuP}$ and margin, and large brown spot near crossvein extending to tornus. Fringe white tipped with brown. Undersurface brown. Hindwing pale brown, gradually darkening to apex.

Abdomen: Male genitalia: Unknown. Female genitalia (Figure 33): Eighth sternum deeply emarginated medially along anterior margin; posterior margin of seventh sternum straight; ductus bursae longer than ovipositor, gradually widening from ostium; inception of ductus seminalis anterior to posterior margin of seventh segment; corpus bursae spherical; signum absent.

Holotype. क, "Bathurst, GAMBIA, XI-1885, Carter, 1886, No. 881"; "Walsingham Collection, 1910427"; "Blastobasis irroratella Wlsm. Tr. Ent. Soc. Lond. 1891. 122-3, Pl. VI-63, Type +, descr.”; "BM Genitalia Slide No. 30237" [BMNH].

Remarks. Although Sinev (2004) examined the holotype female of Blastobasis irroratella, the absence of males makes generic assignment within the Holcocerini unreliable. However, the female features described above are more similar to Holcocera than Tecmerium.

\section{Calosima Dietz, 1910}

Type Species. Calosima argyrosplendella Dietz, 1910 , by original designation.

As with Holcocera, there are fewer Calosima recorded from the Old World than from the New World. Four species of Calosima are known in Thailand, and one species is known from Africa. Species of this genus have an aedeagus that is bulbous basally, a gnathos with a median ridge, and a juxta with an emarginate ventral margin.

\section{Calosima arguta (Meyrick, 1918), new combination}

FIGURES 2, 20, 51

Blastobasis arguta Meyrick, 1918:36.—Janse, 1917:192, check list.

Zenodochium arguta: Sinev, 2004:117.

Diagnosis. Calosima arguta is most similar to C. albafaciella Adamski, 2002 from Thailand, but it differs from the latter species by having a wider gnathos, a narrower spinelike process of the lower part of the valva, and a longer and less curved aedeagus. In Africa, Calosima arguta is most similar to Holcocera extensa in sharing a spinulate anterior part of the ductus bursae and a platelike signum within the corpus bursae. However, because the male of $H$. extensa is not known, relationships between the two species are uncertain.

\section{REDESCRIPTION.}

Head: Vertex and frontoclypeus with scales brown or pale brown tipped with white. Outer and inner surfaces of labial palpus with scales brown tipped with white, apical area of segment II and all of segment III paler. Scape of antenna with scales brown or pale brown tipped with white, flagellum gray, wider and with more cilia in male; first flagellomere unmodified in male. Proboscis with scales brown or pale brown tipped with white.

Thorax: Tegula and mesonotum with scales brown or pale brown tipped with white. Leg scales brown tipped with white intermixed with dark brown scales tipped with white, with a pale brown band near midfemur and apices of all segments and tarsomeres. Forewing (Figure 51) length 6.7-7.0 $\mathrm{mm}(n=3)$, scales brown or dark brown tipped with white, intermixed with pale brown scales, some tipped with white; basal and median fasciae brown or dark brown, complete, bisected by a wide, transverse, white band; apical $1 / 3$ slightly paler than median fascia; large brown spot below distal end of cell near posterior margin. Fringe brown or pale brown tipped with white. Undersurface brown. Hindwing pale brown, slightly darkening to apex.

Abdomen: Male genitalia (Figure 2): Uncus setose, slightly elongate, ventrally keeled, ventral margin serrate; arms of gnathos projecting ventroanteriorly, fused medially, forming a widened band; vinculum narrow; juxta platelike; valva divided; upper part of valva widened basally, gradually narrowed from an abrupt, ventral emargination, produced into a digitate process, apex rounded; lower part of valva wide, subventral area reflexed to apicoventral angle, 
distally produced into an inwardly curved, acuminate process; aedeagus and sclerite of aedeagus broadly curved from base to apex; anellus with several microsetae. Female genitalia (Figure 20): Eighth sternum trapezoid shaped, deeply emarginate anteriorly; posterior margin of seventh sternum straight; ductus bursae about twice as long as ovipositor, narrow throughout length, with microspinules from inception of ductus seminalis to corpus bursae; inception of ductus seminalis posterior to seventh sternum; corpus bursae subovate; signum spiculate, on posterior end of corpus bursae.

Lectotype. Designated herein, $\hat{0}$, "Umkomaas [Natal, South Africa], 6-1[Jan][19]14, A.J.T. Janse"; "M-3831"; "Blastobasis arguta M[eyrick]"; “ $\bigcirc$ Genitalia Slide by D. Adamski, No. 4628" [yellow label]; "Blastobasis arguta M[eyrick] Type No. 805" [TMP]. A lectotype is being designated in order to maintain stability of usage of the name.

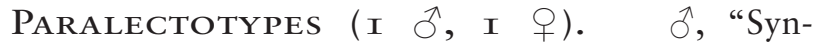
type" [round, blue-bordered label]; "Umkomaas, Natal, A.J.T.J. 18-1[Jan][19]14"; "Blastobasis arguta Meyr[ick], 1/1, E. Meyrick det., in Meyrick Coll[ection]"; "Meyrick Coll[ection], B.M. 1938-290"; "arguta Meyr[ick]”; "B.M. ð Genitalia Slide No. 30235" [BMNH]; ㅇ, "Umkomaas, [Natal], 6-1[Jan][19]14, A.J.T. Janse”; “M-3833”; “o Genitalia Slide by D. Adamski, No. 4629"; "Blastobasis arguta M[eyrick], Cotype No. 806” [TMP].

REMARKs. Sinev (2004) erroneously transferred Blastobasis arguta to Zenodochium. Adamski and Brown (1989) synonomized Zenodochium with Blastobasis, and $H$. arguta possesses holcocerine characters and not blastobasine characters (see Figures 2 and 20).

\section{Blastobasini Meyrick, 1894}

On the basis of holdings in museum collections, Blastobasini are the more numerous of the two tribes of Blastobasinae. Many Old World species have unique male genital features, and the acknowledgment of these features may result in a proliferation of new genera by future workers. Species within Blastobasini may be recognized by having a forewing with a reduced tornus, male tegumen with tergal setae dorsolateral area, vinculum wide, juxta bandlike, anellus with stout setae or with macrosetae, gnathos with arms projecting ventrolaterally, anellus separate from juxta, female with telescopic ovipositor with four membranous divisions posterior to eighth segment, eighth tergum with a darkly pigmented median longitudinal streak, ostium slightly posterior to seventh sternum, and signum hornlike or spinelike.

\section{Neoblastobasis Kuznetzov \& Sinev, 1985}

Type Species. Blastobasis biceratala Park, 1984, by subsequent designation (Kuznetzov and Sinev, 1985).

Neoblastobasis contains about eight species that are found only in the Old World. Members of the genus can be recognized by having a large spinelike projection arising from the base of the lower part of the valva.

\section{Neoblastobasis laikipiae Adamski, new species}

\section{FIGURES 3, 58, MAP 1}

Diagnosis. Neoblastobasis laikipiae is similar to N. wangithiae in wing pattern and male genitalia but differs from the latter by being larger and having the first flagellomere of the antenna unmodified in the male.

DESCRIPTION.

Head: Vertex and frontoclypeus with scales brownish gray tipped with pale gray; labial palpus with outer surface of segments I and II dark brownish gray intermixed with pale gray scales to apical margin, segment III dark brownish gray intermixed with a few pale gray scales; scape of antenna pale gray, flagellum gray; first flagellomere in male unmodified; proboscis pale gray.

Thorax: Tegula and mesonotum pale brownish gray intermixed with pale gray. Legs brownish gray, with a pale gray band on apices of all segments and tarsomeres. Forewing (Figure 58) length $6.3 \mathrm{~mm}(n=1)$, brownish gray intermixed with gray and pale gray; cell with two small gray spots on distal end near crossvein, middle obliterated by gray submedian fascia; submedian fascia complete; area basad of submedian fascia pale gray, base gray; area distad of submedian fascia pale gray, gradually darkening to margin; submarginal spots faint. Undersurface brownish gray. Hindwing pale gray.

Abdomen: Male genitalia (Figure 3): Uncus abruptly curved subapically, apex narrowly rounded; gnathos narrow, dorsoposterior margin bidentate medially; membrane below gnathos microtrichiate; vinculum wide; juxta bandlike; valva divided; upper part with costa distally produced into a setose, digitate process, apical part lobelike; base of costa overlaid by a triangular, densely microtrichiate, membranous covering; lower part of valva wide, bearing a short, basal spinelike process, extending to near $1 / 3$ length of costa; subventral area reflexed to apicoventral margin; apicoventral margin broadly rounded, produced into a inwardly curved, acuminate process; aedeagus and 


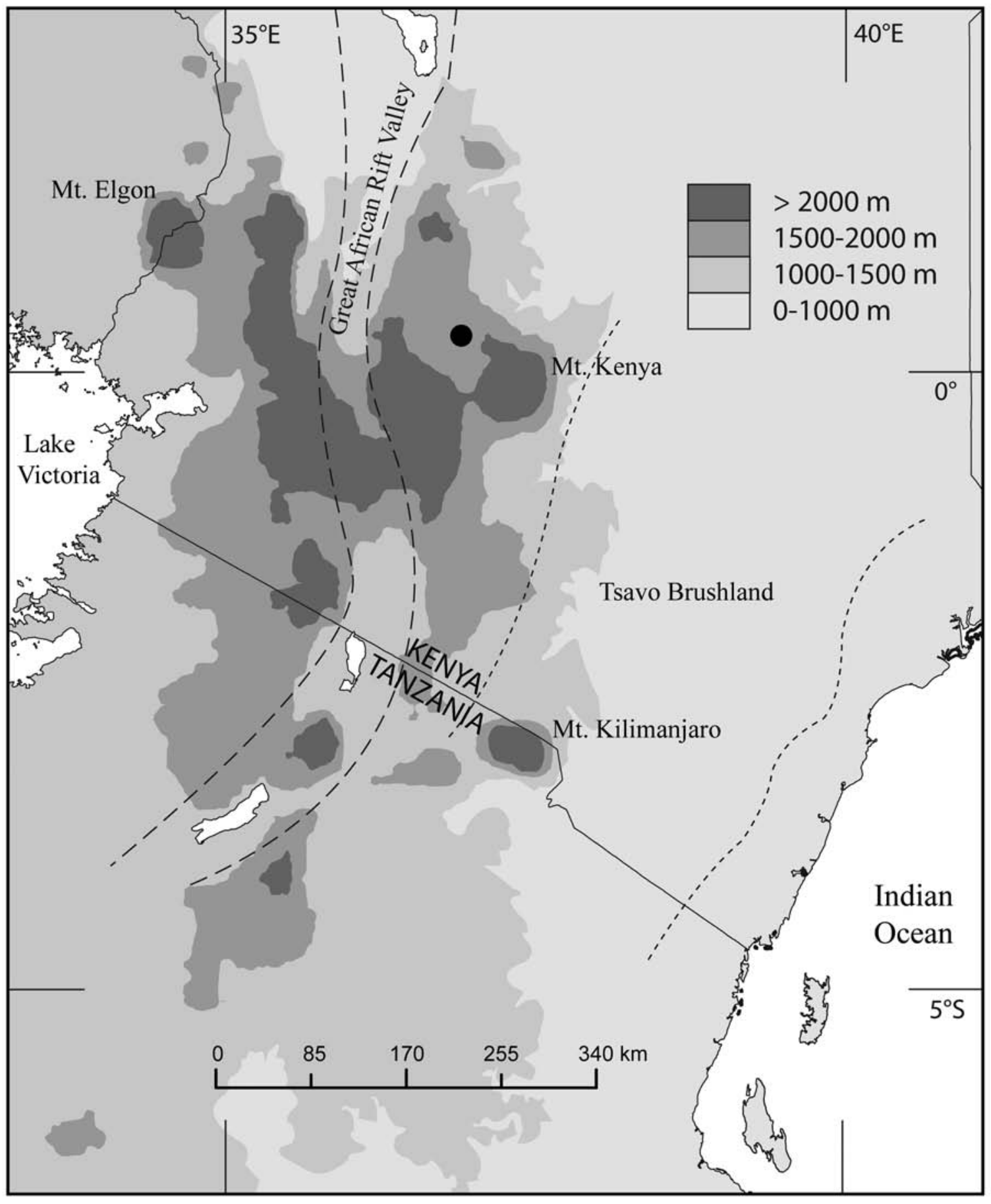

MAP 1. Distribution of Neoblastobasis laikipiae.

sclerite of aedeagus slightly curved near apical 1/3; anellus apically bilobed, bearing several conical setae. Female genitalia: Unknown.

Holotype. $\quad \hat{\jmath}$, "Kenya: Laikipia Plateau, Mpala Research Centre, $0.293^{\circ} \mathrm{N}, 36.899^{\circ} \mathrm{E}, 23-26$ Dec. 1999,
1650 m, S.E. Miller \& T.M. Kuklenski"; "Restrictions Apply, NMK-ICIPE, Agreement \# 5" [purple label]; “ 0 Genitalia Slide by D. Adamski, No. 4144” [yellow label]; "USNM ENT 00194974" [barcode label] [hindwings in gelatin capsule attached to pinned specimen] [NMK]. 
Etymology. The species epithet, laikipiae, is derived from the geographical locality where the species is known to occur.

Distribution. Neoblastobasis laikipiae is known only from the eastern escarpment of the Rift Valley, known as the Laikipia Plateau.

Remarks. Neoblastobasis laikipiae and the following three species represent the first records of Neoblastobasis in Africa.

\section{Neoblastobasis wangithiae Adamski, new species}

FIGURES 4, 54, MAP 2

Diagnosis. Neoblastobasis wangithiae is similar to N. laikipiae in wing pattern and male genitalia but differs from the latter by having the first flagellomere of the antenna notched in the male.

DESCRIPTION.

Head: Vertex and frontoclypeus pale brown, most scales missing; labial palpi missing; scape of antenna pale brown, flagellum gray; first flagellomere of male basally dilated, forming a notchlike concavity; proboscis pale brown.

Thorax: Tegula pale brown; mesonotum dark brownish gray anteriorly, pale brown posteriorly. Legs missing. Forewing (Figure 54) length $4.1 \mathrm{~mm}(n=1)$, pale brown intermixed with brown and brown scales tipped with white; median fascia faint; cell with three small, faint spots, one near middle and two on tornus; marginal spots faint. Undersurface dark brown. Hindwing pale gray.

Abdomen: Male genitalia (Figure 4): Uncus abruptly curved subapically, apex broadly rounded; gnathos narrow, dorsoposterior margin bidentate medially; membrane below gnathos sparsely microtrichiate; vinculum wide; juxta bandlike; valva divided; upper part wide basally, developed apically into a setose, digitate process, apical part lobelike; base of costa overlaid by a triangular, microtrichiate, membranous covering; lower part of valva wide, bearing a short, basal spinelike process, extending about $1 / 3$ length of costa, subventral area reflexed to apicoventral margin; apicoventral margin angular, produced into an inwardly curved, acuminate process; aedeagus slightly curved near middle, sclerite of aedeagus curved near apical 1/3; anellus subconical, bearing several conical setae. Female genitalia: Unknown.

Holotype. $\sigma^{\lambda}$, "Kenya: Gongoni Forest, $4^{\circ} 24.37^{\prime} \mathrm{S}, 39^{\circ} 28.26^{\prime} \mathrm{E}, 3$ May 2001, A \& M Coll[ection] \# 1255, R.S. Copeland, ICIPE/USAID, r.f. Pleiocarpa pycnantha"; "Restrictions Apply, NMK-ICIPE, Agreement \#
5" [purple label]; “ $\widehat{O}$ Genitalia Slide by D. Adamski, No. 5044” [yellow label]; "USNM ENT 00196948” [barcode label] [NMK].

ETYMOLOGY. This species is named in honor of Juliet Wangithi Muriuki, who provided technical support for the collection of fruit and reared many of the moth specimens included in this paper.

Distribution. Neoblastobasis wangithiae is restricted to coastal lowland habitats in southeastern Kenya.

Host. Pleiocarpapycnantha (K. Schum.) (Apocynaceae).

\section{Neoblastobasis perisella Adamski, new species}

FIGURES 5, 21, 62, MAP 3

Diagnosis. Neoblastobasis perisella is most similar to N. ximeniaella but differs from the latter by having a narrower uncus, fewer tergal setae, a more elongate basal spinelike process on the lower part of the valva, and a more acutely curved apical part of the aedeagus.

\section{DESCRIPTION.}

Head: Vertex pale brown; frontoclypeus pale brown with brown scales on lateral margin. Labial palpus with widened segments, segment II as wide as scape, inner surface flattened, pale brown; outer surface with segment I and basal half of segment II brown, distal half of segment II and segment III pale brown; scape of antenna pale brown, flagellum brownish gray; first flagellomere of male basally dilated, forming a notchlike concavity. Proboscis pale brown.

Thorax: Tegula and mesonotum pale brown intermixed with some brown scales basally. Legs pale brown intermixed with brown scales tipped with white, with a white band near middle of all segments and apices of all segments and tarsomeres. Forewing (Figure 62) length 5.1-5.5 mm $(n=2)$, pale brown from base to near midcell, except for some brown scales along costa, brown scales and pale brown scales tipped with brown intermixed with fewer pale brown scales from midcell to outer margin; a brown midcell spot and a faint spot near distal end of cell. Fringe pale brown intermixed with brown scales tipped with pale brown. Undersurface brown. Hindwing pale grayish brown.

Abdomen: Male genitalia (Figure 5): Uncus narrowed medially, slightly broadened apically; gnathos narrow, dorsoposterior margin bidentate medially; membrane below gnathos microtrichiate; vinculum wide; juxta divided; valva divided; costa of upper part basally narrow, developed into a setose, digitate process apically; costa base overlaid by a triangular, densely microtrichiate, membranous covering; 


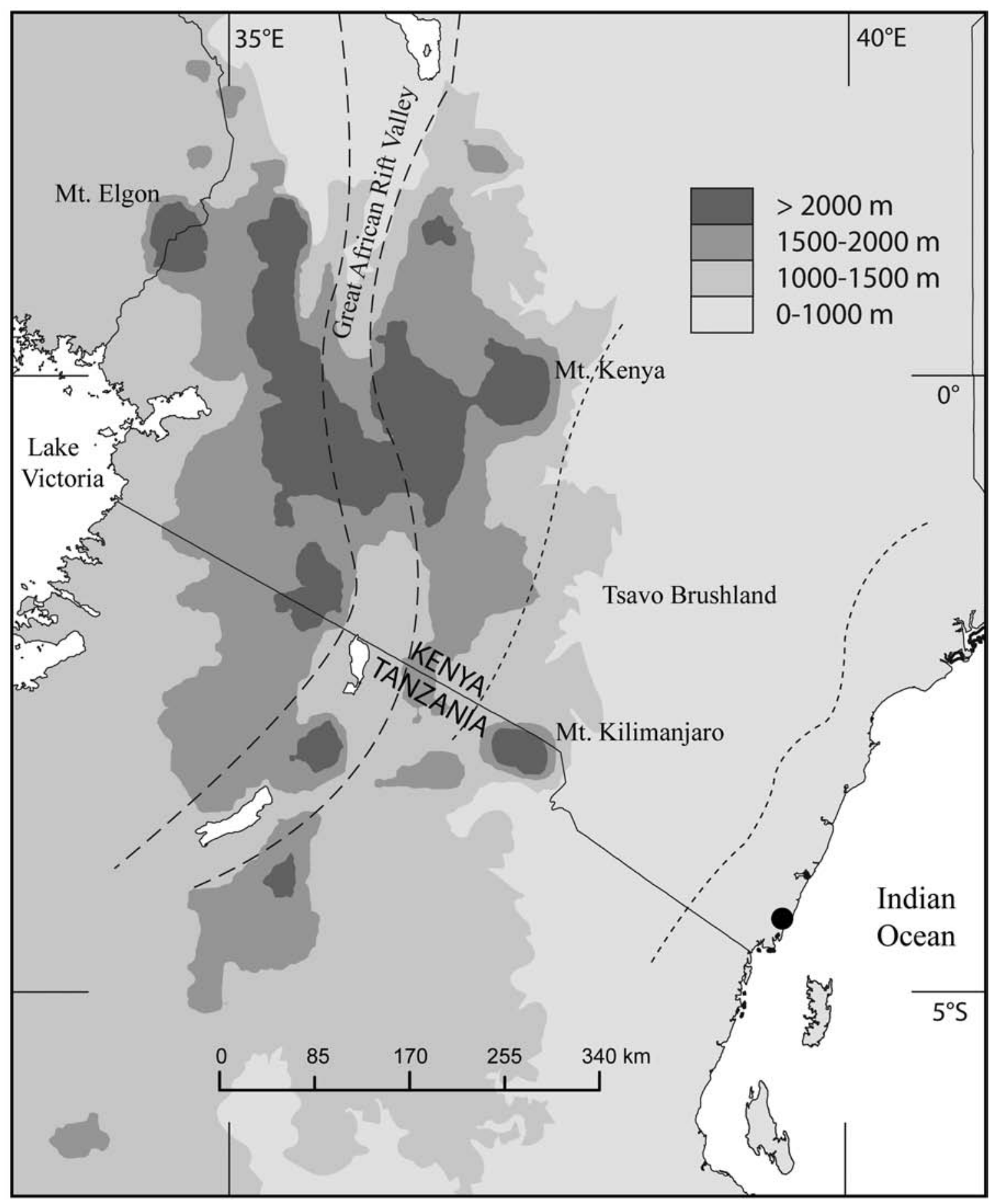

MAP 2. Distribution of Neoblastobasis wangithiae.

lower part of valva wide, bearing a long, broadly curved spinelike process, extending beyond lower part of valva to near apex of digitate process of upper part of valva; subventral marginal part reflexed to apicoventral margin; apicoventral margin broadly rounded, produced apically into an inwardly curved, acuminate process; aedeagus and sclerite of aedeagus curved near apical 1/3; anellus narrowly acuminate, with several conical setae. Female genitalia (Figure 21): Eighth tergum without narrow, darkly pigmented streak on median longitudinal axis; membrane surrounding 


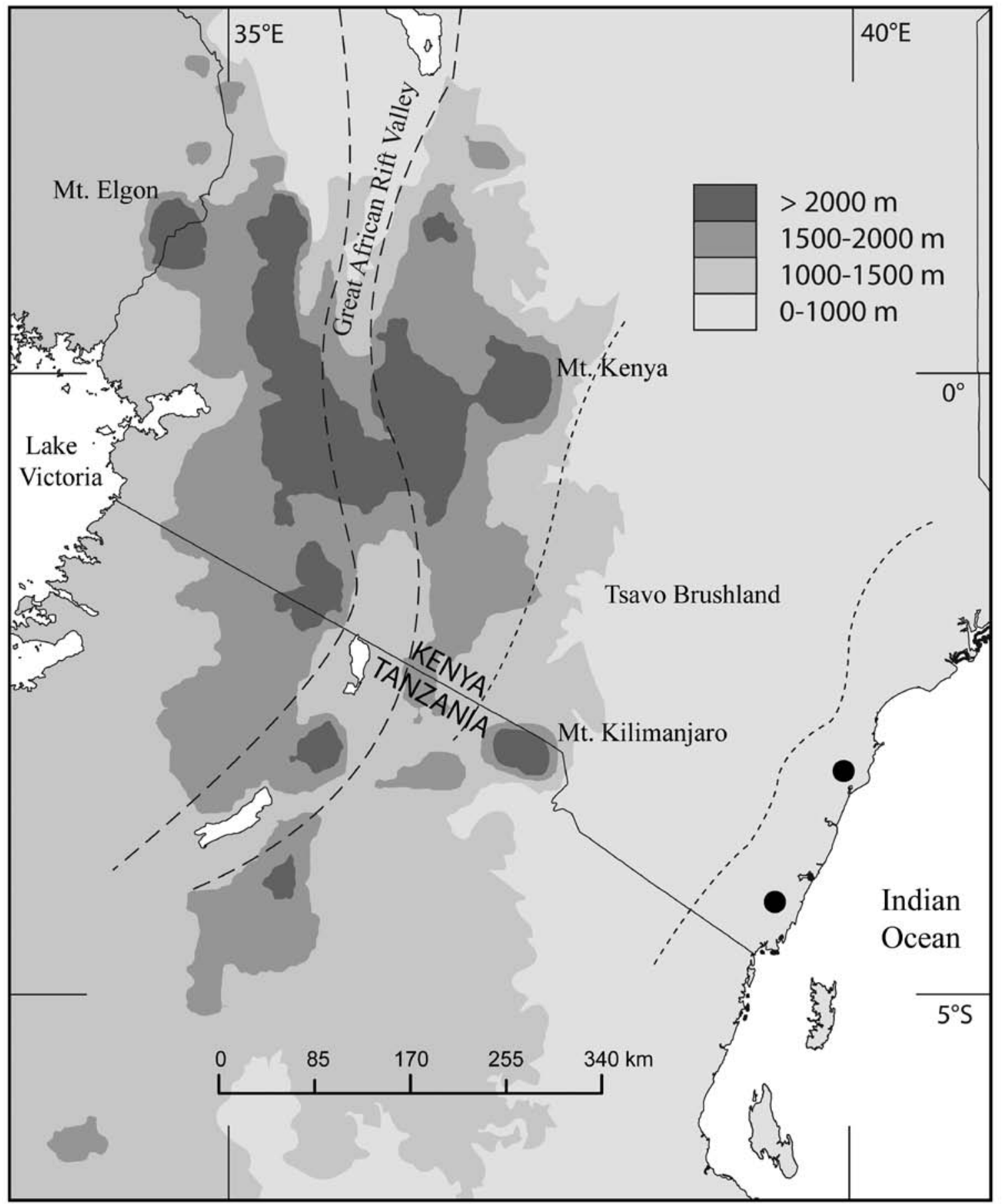

MAP 3. Distribution of Neoblastobasis perisella.

ostium lacking microtrichiae; seventh sternum with spinelike setae; ductus bursae about half as long as ovipositor, with internal imbricate platelets in anterior half; inception of ductus seminalis slightly anterior to ostium; signum capitulate, with an elongate spinelike inner process.
Holotype. đ, "Eala, Belgium Congo [Democratic Republic of Congo], JC, 8- [19]35"; "Blastobasis byrsodepta Mey[rick], 8/8, E. Meyrick det., in Meyrick Coll[ection]"; "Meyrick Coll[ection], BM 1938-290"; "BM §̊ Genitalia Slide No. 30238” [BMNH]. 
Paratypes ( I $\hat{\delta}$, I ㅇ). $\hat{O}$, “Kenya: Shimba Hills, 389 m, 4 $15.42^{\prime}$ S, 39²2.96'E, 9 Aug. 2002, A \& M Coll[ection] \# 2142, R.S. Copeland, ICIPE/USAID, r.f. Hugonia castaneifolia"; “ 1 Slide 4911”; "00196947”, [NMK]; ㅇ, "Kenya: Arabuko-Sokoke Forest, $3^{\circ} 12.18$ 'S, 3955.63'E, 3 Jan. 2001; A \& M Coll. \# 960, R.S. Copeland, ICIPE/USAID, r.f. Ximenia caffra”; “o Slide 5103”; “00196946" [NMK].

ETYMology. Neoblastobasis perisella is named in honor of Peris Machera, an extraordinary and tireless worker in the insect-rearing laboratory in Nairobi, Kenya.

Distribution. Neoblastobasis perisella is restricted to coastal lowland habitats in southeastern Kenya.

Hosts. Hugonia castaneifolia Engl. (Linaceae), and Ximenia caffra Sond. (Olacaceae).

Remarks. Although the holotype of Neoblastobasis perisella possesses Meyrick's syntype labels bearing the name B. byrsodepta, the specimen is not part of the original series from which the latter species was described.

\section{Neoblastobasis ximeniaella Adamski, new species}

FIGURES 6, 22, 53, MAP 4

Diagnosis. Neoblastobasis ximeniaella is most similar to N. perisella but differs from the latter by having a wider uncus, more tergal setae, a shorter spinelike process on the lower part of the valva, and a straight aedeagus.

DESCRIPTION.

Head: Vertex and frontoclypeus pale brown; labial palpus missing; scape of antenna pale brown; first flagellomere basally dilated, forming a notchlike area between dilation and flagellomeres 2-4, distal flagellum missing; proboscis pale brown.

Thorax: Tegula and mesonotum dark gray basally, pale brown distally. Legs missing. Forewing (Figure 53) length $6.1-6.7 \mathrm{~mm}(n=2)$, pale brown intermixed with a few dark gray scales; base of costa with a few dark gray scales; median fascia absent; cell with three dark gray spots, one near midcell and two parallel with crossvein near distal end. Undersurface brown. Hindwing pale gray.

Abdomen: Male genitalia (Figure 6): Uncus abruptly curved subapically, apex broadly rounded; gnathos narrow, dorsoposterior margin bidentate medially; membrane below gnathos microtrichiate; vinculum wide; juxta bandlike; valva divided; basal 1/3 of costa of upper part overlaid by an elongate covering of dense microtrichiate membrane; distal 2/3 developed into a setose, digitate process; lower part of valva wide, bearing a straight spinelike process, extending to near base of acuminate process of lower part of valva; subventral area reflexed to apicoventral margin; apicoventral margin rounded, produced into an inwardly curved, acuminate process; aedeagus straight, sclerite of aedeagus abruptly curved near apical 1/3; anellus bearing several conical setae. Female Genitalia (Figure 22): Eighth tergum without a narrow, darkly pigmented streak on median longitudinal axis; membrane surrounding ostium not microtrichiate; a pair of short, membranous, lobelike, invaginations posterolateral to ostium; posterior margin of seventh sternum straight; ductus bursae about as long as ovipositor, with imbricate platelets on anterior end; inception of ductus seminalis anterior to a short membranous antrum; corpus bursae with a hornlike signum arising from a small base.

Holotype. $\partial^{\lambda}$, "Kenya: Arabuko-Sokoke Forest, $3^{\circ} 12.18^{\prime} \mathrm{S}, 39^{\circ} 55.63^{\prime} \mathrm{E}, 3$ Jan. 2001, A \& M Coll[ection] \# 960, R.S. Copeland, ICIPE/USAID, r.f. Ximenia caffra"; "Restrictions Apply, NMK-ICIPE, Agreement \# 5" [purple label]; “ \ Genitalia Slide by D. Adamski, No. 5052" [yellow label]; "USNM ENT 00196943” [barcode label]; "DNA" [blue label] [NMK].

Paratypes ( I $\hat{\jmath}, 2$ 우). $1 \hat{\delta}, 1$ ㅇ, Same label data as holotype except, "101 m"; “ $О$ Slide 5057"; "00196944"; "Genitalia Slide by DA, USNM 83367" [USNM]; “ $\circ$ Slide 5104”; “00196945”, + Genitalia Slide by DA, USNM 83369" [USNM]; 1 , same as above except, "Kaya Kinondo, 4²3.93'S, 39³1.96'E, 7 July 2001, A \& M Coll. \# 1370, R.S. Copeland; ICIPE/USAID, r.f. Calophyllum inophyllum"; “o Slide 5851" "00196415"; “o Genitalia Slide by DA, USNM 83368.” All paratypes deposited in USNM.

ETymology. The species epithet, ximeniaella, is derived from the generic name of the plant from which the moth was first reared.

Distribution. Neoblastobasis ximeniaella is restricted to coastal lowland habitats in southeastern Kenya.

Host. Ximenia caffra Sond. (Olacaceae), Calophyllum inophyllum L. (Clusiaceae).

\section{Blastobasis Zeller, 1855}

Type Species. Oecophora (Scythris) phycidella Zeller, 1839, by subsequent designation (Walsingham, 1907).

Blastobasis is closely related to Neoblastobasis, but in the absence of a phylogenetic analysis their relationship is uncertain. Species of Blastobasis can be recognized by having a dilated first flagellomere of the antenna with an inner surface bearing palmate scales and corpus bursae with a posterior lobe near inception of ductus bursae. 


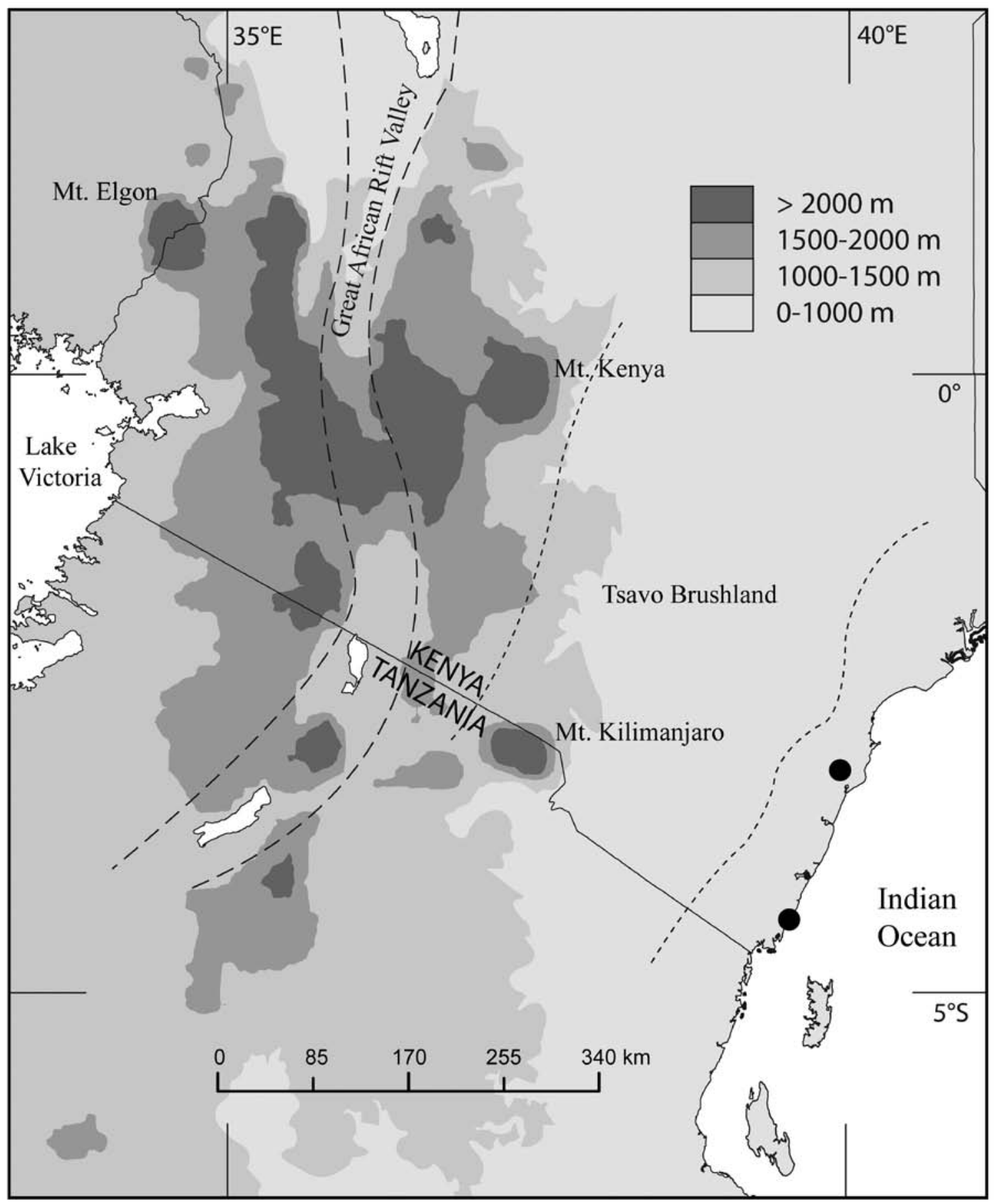

MAP 4. Distribution of Neoblastobasis ximeniaella.

\section{Blastobasis millicentae Adamski, new species}

FIGURES 9, 38, MAP 5

Diagnosis. Blastobasis millicentae is easily distinguished from its congeners by having the following autapomorphies: an angular basal part of the costa of the upper part of the valva and a large spinelike seta on the ventral ridge of the base of the valva.

DESCRIPTION.

Head: Vertex and frontoclypeus with scales pale brownish gray tipped with white. Outer surface of labial 


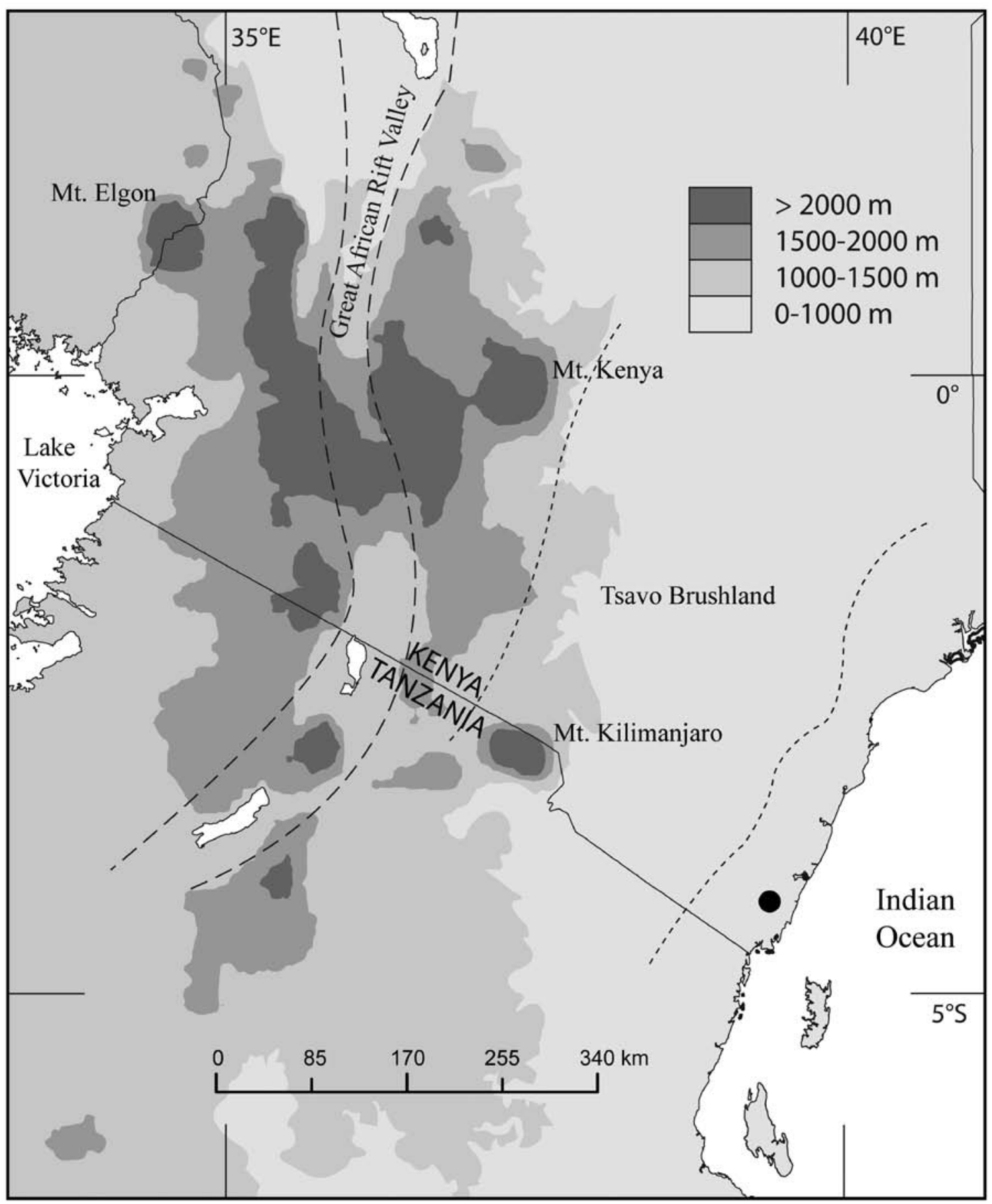

MAP 5. Distribution of Blastobasis millicentae.

palpus white intermixed with brown, inner surface white. Scape of antennae brownish gray intermixed with white, flagellum pale gray; first flagellomere of male basally dilated laterally, forming a notchlike concavity. Proboscis white.
Thorax: Tegula and mesonotum with brown scales tipped with white. Legs with brown scales tipped with white and a white band on apices of all segments and tarsomeres. Forewing (Figure 38) length 4.1-4.5 mm $(n=2)$, pale brown on basal $2 / 3$ intermixed with a few brown 
scales, brown intermixed brown scales tipped with white and pale brown scales on distal 1/3; a brown spot in cell near distal end. Fringe brown tipped with white. Undersurface brown. Hindwing pale brown.

Abdomen: $\quad$ Male genitalia (Figure 9): Uncus wide, narrowed distally into a slightly rounded apex; gnathos wide, dorsoposterior margin protuberant, bidentate medially; vinculum wide; juxta divided; valva divided; upper part of valva setose, apically digitate; base of digitate process bifurcate, costal arm angled beyond dorsal articulation, ventral arm reflexed ventrally forming an upturned ridge fusing with lower part of valva; ridge bearing a moderately large, spinelike seta; lower part of valva wide, subventral area reflexed to apicoventral margin; apicoventral margin moderately angular, produced into an inwardly curved, acuminate process; aedeagus and sclerite of aedeagus slightly curved broadly; anellus slightly elongate conical, bearing several conical setae. Female genitalia: Unknown.

Holotype. $\hat{O}$, "Verulam, [South Africa] 28.1[January][19]16, A.J.T. Janse"; "26/75"; "Blasto-

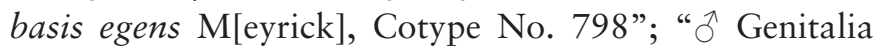
Slide by D. Adamski, No. 4739" [TMP].

Paratype. $\hat{o}$, "Kenya, Shimba Hills, $389 \mathrm{~m}$, $4^{\circ} 15.42^{\prime}$ S, 39²2.96'E, 9 Aug. 2002, A \& M Coll[ection] \# 2139, R.S. Copeland, ICIPE/USAID, r.f. Hirtella zanzibarica fruit”; “ $\lesssim$ Slide 4910”; “00196942” [NMK].

ETYMOLOGY. Blastobasis millicentae is named in honor of Millicent Okumu, who, with great skill, managed the laboratory insect-rearing program in Nairobi, Kenya.

Distribution. Blastobasis millicentae is restricted to coastal lowland habitats in southeastern Kenya.

Host. Hirtella zanzibarica Oliv. (Chrysobalanaceae).

ReMARKs. The holotype of Blastobasis millicentae is from the type series of B. egens.

\section{Blastobasis kenya Adamski, new species}

FIGURES 10, 27, 60, MAP 6

Diagnosis. Blastobasis kenya is similar to B. acirfa and B. aynekiella but differs from the latter two species by having a gnathos that is narrower, an acuminate distal process of the lower part of the valva that is nearly cylindrical, and female with a base of signum that is angular.

DESCRIPTION.

Head: Vertex and frontoclypeus with scales grayish brown tipped with pale brown; outer and inner surfaces of labial palpus with segment I dark gray; segment II dark gray, pale brown subapically; segment III pale brown intermixed with few dark gray scales; scape of antenna and first flagellomere pale brown intermixed with few dark gray scales in both sexes, flagellum dark gray; first flagellomere of antenna dilated, forming a notchlike concavity between dilation and flagellomeres 2-4 in male; proboscis grayish brown.

Thorax: Tegula and mesonotum dark gray basally, grayish-brown scales tipped with pale brown distally. Legs dark gray with a pale brown band near midlength of segments and apices of all segments and tarsomeres. Forewing (Figure 60) length 6.0-9.2 $\mathrm{mm}(n=45)$, grayish brown intermixed with pale brown and dark brown, or pale brown basally, grayish brown distally; costa grayish brown intermixed with a few dark gray scales; basal area with irregular patches of dark gray; median fascia complete or incomplete; cell with three small dark gray spots, one near midcell and two parallel to crossvein near end of cell; marginal spots dark gray or faint. Undersurface brown. Hindwing gray.

Abdomen: Male genitalia (Figure 10): Uncus abruptly narrowed from base near $1 / 2$ length, gradually narrowed to an acuminate apex; gnathos narrow, dorsoposterior margin bidentate medially; vinculum wide; juxta bandlike; valva divided; costa of upper part developed into a setose, digitate process; proximal flange elongate, overlaid by dense microtrichiate membrane, narrowed distally, contiguous with digital process; lower part of valva moderately wide, subventral area reflexed to apicoventral margin; apicoventral margin angular, produced into an inwardly curved, cylindrically acuminate process; diaphragm aedeagus microtrichiate; aedeagus and sclerite of aedeagus abruptly curved near apical 1/3; anellus bearing several conical microsetae near base; vesica near anellus with several hairlike apical cornuti. Female genitalia (Figure 27): Eighth tergum with a narrow, darkly pigmented streak on median longitudinal axis; membrane surrounding ostium densely microtrichiate to lateral margin; ductus bursae about a long as ovipositor, with internal imbricate platelets on anterior half; inception of ductus seminalis slightly anterior to ostium; corpus bursae with a short spinelike process on an angular base.

Holotype. $\hat{\sigma}$, "Kenya: Karu/Brooks, ca. $0^{\circ} 8.87^{\prime} \mathrm{S}, 35^{\circ} 15.77^{\prime} \mathrm{E}$, Coll[ected] 17 Aug. 2000, R. Copeland, Lot 808, r.f. Flacourtia indica fruit"; "Restrictions Apply, NMK/ICIPE, Agreement \# 5" [purple label]; “ O Genitalia Slide by DA, No. 4218” [yellow label]; “USNM ENT 00196941" [barcode label], [holotype is missing labial palpi] [NMK].

Paratypes (20 ô, 39 9 ). 1 \% , Same label data as above except, “1614 m, 008.87'S 36²15.77'E”; 
“o Slide 5079”; “00196346”; “ㅇ Genitalia Slide by DA, USNM 83370" [USNM]; 1 क , same label data as above except, " $0{ }^{\circ} 07.353^{\prime} \mathrm{S}, 35^{\circ} 16.254^{\prime} \mathrm{E}, 28$ April 2001, A \& M Coll. \# 1202"; "r.f. Vepris nobilis"; "ㅇ Slide 5107"; "00196368"; "O Genitalia Slide by DA, USNM 83371" [USNM]; 1 o, 3 q, “Kenya: Shimba Hills, 389 m, $4^{\circ} 15.42$ 'S, 39²2.96'E, 9 Aug. 2002, A \& M Coll. \# 2114, r.f. Trilepisium madagascariense"; " 0 Slide 4902"; "00196289"; “ 0 Genitalia Slide by DA, USNM 83372" [USNM]; “우 Slide 4919"; "00196325”; "ᄋ Genitalia Slide by DA, USNM 83373" [USNM]; "O Slide 5098”; "00196362” [NMK]; “o Slide 4918”; “00196324” [NMK]; 2 , data as above except, "A \& M Coll. \# 2118, r.f. Landolphia sp.”; “o Slide 5113”; “00196374”, “ $ф$ Genitalia Slide by DA, USNM 83374” [USNM]; “00196417” [USNM]; 1 ô, "A \& M Coll. \# 2128, r.f. Xylopia parviflora"; " 4908”; "00196292” [BMNH]; 1 ㅇ, "A \& M Coll. \# 2139, r.f. Hirtella zanzibarica”; "o Slide 5118”; "00196378” [NMK]; 2 ô, "10 Aug. 2002, A \& M Coll. \# 2140, r.f. Diospyros kabuyeana"; " $\widehat{\gamma}$ Slide 4903"; "00196290" [NMK]; “ „ Slide 4913”; “00196294” [NMK]; 1 ภ, "A \& M Coll. \# 2111, r.f. Adenia sp.”; “ ○े Slide 4904”; "00196291"; " $\Uparrow$ Genitalia Slide by DA, USNM 83375" [USNM]; 1 +, “A \& M Coll. \# 2131, r.f. Chrysophyllum

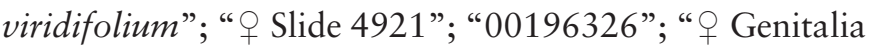
Slide by DA, USNM 83376” [USNM]; 1 oे, “4¹4.27'S, 39²3.74'E, 436 m, 8 Aug. 2002, A \& M Coll. \# 2097, r.f. Dracaena mannii"; “ô Slide 4912”; “00196293”; “ 0 Genitalia Slide by DA, USNM 83377" [USNM]; 1 ㅇ, "4¹4.68S, 39²5.30E, 398 m, 9 Aug. 2002, A \& M Coll. \# 2075, r.f. Rourea minor"; "o Slide 4916”; “00196322” [BMNH]; 4 ㅇ, "Coast Prov., Shimba Hills, $4^{\circ} 14.27^{\prime} \mathrm{S}$, 39²3.74'E, 22.IV.2002, R.S. Copeland"; “ex Fruits Mimusops aedificatoria, ICIPE/USAID, Coll. \# 1909”; "o Slide 5076"; "00196940" [BMNH]; "00196411" [USNM]; "00196409” [USNM]; "00196408” [USNM]; 1 ô, “4²15.696'S, 39²2.747'E, 23.IV.2002, R. S. Copeland"; "ex Hirtella zanzibarica, ICIPE/USAID Coll. A \& M 1919"; “ đ Slide 5065"; “00196319” [NMK]; 1 đo, “4¹5.696'S, 39²2.747'E, 23.IV.2002, R.S. Copeland"; "ex fruits, Hirtella zanzibarica, ICIPE/USAID, Coll. \# 1919”; “ స Slide 5064”; “00196316”, “ స Genitalia Slide by DA, USNM 83378” [USNM]; 1 ô, "4¹5.696'S, $39^{\circ} 22.747$ 'E, 23.IV.2002, R.S. Copeland"; "ex fruits, Hir-

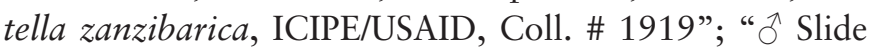
by 5063"; "00196315" [NMK]; 1 \&, data as above except, “ $4^{\circ} 14.27^{\prime} \mathrm{S}, 39^{\circ} 23.74$ 'E, 22.IV.2002"; “ex fruits, Cola minor, ICIPE/USAID, Coll. \# 1906”; “o Slide 5101"; "00196365" [NMK]; 1 +, data as above except, “407 m, 4²12.330'S, 39²6.412'E, 10 Aug. 2002, A \& M
Coll. \# 2070, r.f. Toddalia asiatica”; “ㅇ Slide 5091”; “00196355”; “ㅇ Slide 5101”; "00196355”; “ㅇ Genitalia Slide by DA, USNM 83395" [USNM]; 1 ô, "Kenya: Kaya Kinondo, $4^{\circ} 23.71$ 'S, 39³2.84'E, 5 m, 9 June 2000, A \& M Coll. \# 737, R.S. Copeland, ICIPE/USAID, r.f. Diphasia sp.”; “へ Slide 5053”; "00196312” [NMK]; 1 웅 data as above except, " $4^{\circ} 23.93$ 'S, 39³1.96' $\mathrm{E}, 10 \mathrm{~m}, 7$ July 2001, A \& M Coll. 1359, r.f. Oxyanthus goetzei ssp. keniensis"; "o Slide 5038”; "00196304”; “o Genitalia Slide by DA, USNM 83379" [USNM]; 1 엉 data as above except, “4²3.71'S, 39³2.84'E, 5 m, 21 July 2000, lot 779, Terminalia catappa fruit"; “00196427” [USNM]; 1 o, data as above except, “ $4^{\circ} 23.93$ 'S, $39^{\circ} 31.96$ 'E, A \& M Coll. \# 1369, r.f. Terminalia catappa"; "00196419" [USNM]; $2 \delta^{\lambda}$, data as above except, " $4^{\circ} 23.71$ 'S, $39^{\circ} 32.84^{\prime} \mathrm{E}, 5$ m, Coll. 20 July 2000, Kip - 654, r.f. Ter-

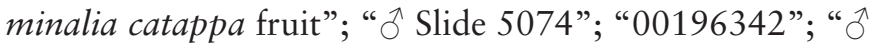
Genitalia Slide by DA, USNM 83380" [USNM]; “ 0 Slide 4351"; "00196331” [NMK]; 1 ठ , data as above except, "Coll. 21 July 2000, Coll. A \& M - 779, r.f. Terminalia catappa fruit"; “ô Slide 4229"; “00196300" [NMK]; $1 \mathrm{O}$, data as above except, " 5 m, 9 Feb. 2003, A \& M Coll. \# 2503, r.f. Inhambanella henriquezii”; "Ô Slide 5018”; "00196302”; “ స Genitalia Slide by DA, USNM 83381" [USNM]; 1 ㅇ, data as above except, "Coll. 20 July 2000, Coll. A \& M 763, r.f. Olea woodiana disjuncta fruit"; “O Slide 4363”; "00196340" [NMK]; 1 ภ, data as above except, “4 ${ }^{\circ} 23.93$ 'S, $39^{\circ} 31.96$ 'E, 7 July 2001, A \& M Coll. \# 1346, r.f. Ludia mauritiana"; “令 Slide

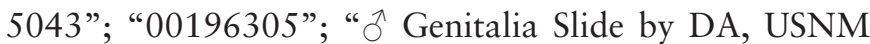
83382" [USNM]; 1 ㅇ, data as above except, "A \& M Coll. \# 1370, r.f. Calophyllum inophyllum”; “o Slide 5114"; "00196375”; " $\bigcirc$ Genitalia Slide by DA, USNM 83383” [USNM]; 1 क , “A \& M Coll. \# 1369, r.f. Ter-

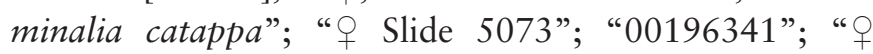
Genitalia Slide by DA, USNM 83384” [USNM]; 1 ㅇ, “4²3.93'S, 39³1.96'E, 7.VII.2001, R.S. Copeland"; "ex fruits, Terminalia catappa, ICIPE/USAID, Coll. \# 1369"; “o Slide 5075"; "00196343”; " $\bigcirc$ Genitalia Slide by DA, USNM 83385” [USNM]; 1 ㅇ, "Arabuko Sokoke Forest, ca. $3^{\circ} 18.01^{\prime} \mathrm{S}, 39^{\circ} 59.14$ 'E, Coll. 15 May 2000 , R. Copeland, Kip - 548, r.f. Deinbollia borbonica fruit”; “o Slide 4360"; "00196338"; "O Genitalia Slide by DA, USNM 83386" [USNM]; 1 ㅇ, data as above except, "Coll. 16 May 2000, Kip - 559, r.f. Manilkara sansibarensis fruit"; "q Slide 4358”; "00196336”; “ $申$ Genitalia Slide by DA, USNM 83387" [USNM]; 1 ${ }^{\lambda}$, data as above except, "ca. $3^{\circ} 19.32^{\prime} \mathrm{S}$, 3957.48'E, Coll. 9 Jan. 2000, Kip - 339, r.f. Ximenia caffra”; “ð Slide 4219”; “00196295”; “О Genitalia Slide by DA, USNM 83388” [USNM]; 1 ㅇ, 


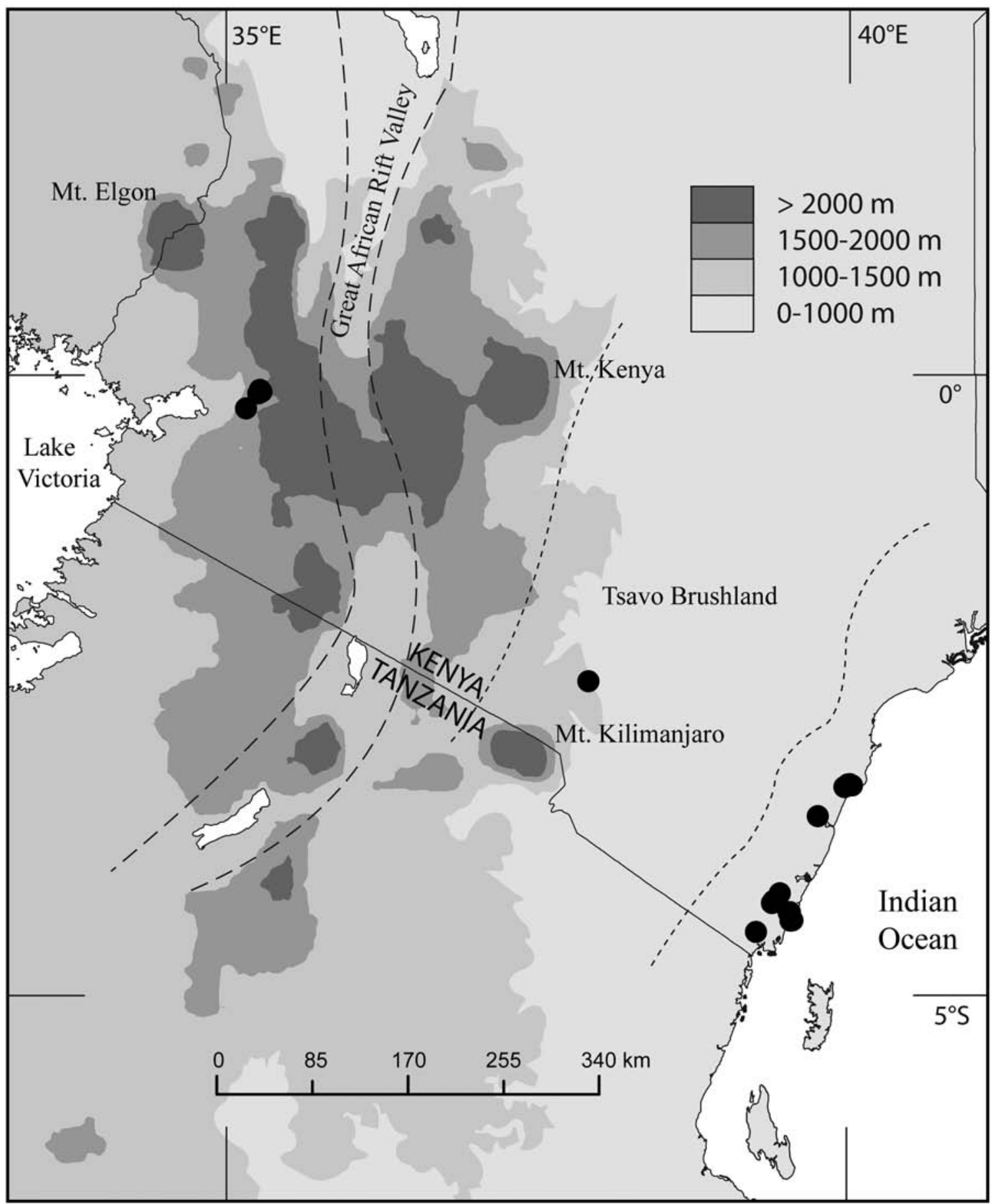

MAP 6. Distribution of Blastobasis kenya. 
data as above except, " $3^{\circ} 18^{\prime}$ S, $39^{\circ} 59^{\prime} \mathrm{E}, \mathrm{A} \& \mathrm{M}$ Coll. \# 423, r.f. Strychnos madagascariensis, form e"; “o Slide 5089"; "00196353" [NMK]; 1 ô, 3 ㅇ, data as above except, "3¹7.921'S, 3959.994'E, 25 Aug. 1999, Kip 128, r.f. Salacia elegans"; "O Slide 5080”; "00196347” [NMK]; 2 0,3 o, data as above except, "Gede Forest, ca. $3^{\circ} 18.563^{\prime} \mathrm{S}, 40^{\circ} 1.076$ 'E, Coll. 2 April 1999, R. Copeland, Coll. A \& M 51, r.f. Lepisanthes senegalensis fruit";

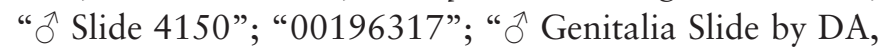
USNM 83389” [USNM]; “ $\widehat{O}$ Slide 5115”; “00196865”; “o Slide 4148”; “00196384”; “00196385”; “00196416” [MRAC]; 1 今े, “ $3^{\circ} 18.47$ 'S, $40^{\circ} 01.05^{\prime} \mathrm{E}, 23-\mathrm{V}-2000$, R. Copeland, Kip - 571, Lecaniodiscus fraxinifolius fruit"; “ 7 Slide 5054"; "00196313” [NMK]; “o Slide 5101”; "00196365" [NMK]; 1 o, data as above except, "Arabuko Sokoke Forest, ca. $3^{\circ} 18.01$ 'S, 3959.14'E, Coll. 15 May 2000, R. Copeland, Kip - 548, r.f. Deinbollia borbonica fruit”; “o Slide 4360”; “00196338” [NMK]; 1 ô, data as above except, "Kenya: Muhaka Forest, $4^{\circ} 19.76$ 'S, 39³1.55'E, 2 May 2001, A \& M Coll. \# 1224, R.S. Copeland, r.f. Diospyros sp.”; “ 1 Slide 5051”; “00196311”; “ $\widehat{O}$ Genitalia Slide by DA, USNM 83390” [USNM]; 1 ㅇ, data as above except, “4²19.88'S, 39³1.02'E, 12 April 2000, Kip - 483, R.S. Copeland, ICIPE/USAID, Reared

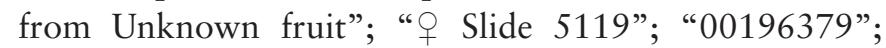
“ $O$ Genitalia Slide by DA, USNM 83391" [USNM]; 1 ${ }^{7}, 1$ \&, data as above except, "Mrima Hill, $4^{\circ} 29.25^{\prime} \mathrm{S}$, 39¹5.37'E, 3 May 2001, A \& M Coll. \# 1221, R.S. Copeland, ICIPE/USAID, r.f. Dovyalis macrocalyx"; “๙ Slide 5047"; "00196307"; "今 Genitalia Slide by DA, USNM 83392" [USNM]; “o Slide 5086”; "00196350”; " + Genitalia Slide by DA, USNM 83396" [USNM]; 1 , data as above except, "A \& M Coll. \# 1223, R.S. Copeland, ICIPE/USAID, r.f. Saba comorensis"; "o Slide 5085"; "00196349” [NMK]; 1 \% , data as above except, "Western Koru, Coffee Research Station, 008.202'S, 35¹7.086'E, 5.VIII.1999, A \& M 232, unknown plant”; “o Slide 5122"; "00196382”; " $\bigcirc$ Genitalia Slide by DA, USNM 83393" [USNM];1 9 , data as above except, "Kericho/Kisumu Road, ca. $0^{\circ} 16.189^{\prime}$ S, 3509.682'E, Coll. 21 Nov. 1999, R. Copeland, Coll. A \& M 361, r.f. Vepris

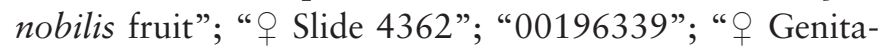
lia Slide by DA, USNM 83394" [USNM]; 1 엉 data as above except, "1615 m, 21 Nov. 1999, A \& M Coll. \# 361, r.f. Vepris nobilis”; “00196407” [USNM]; 1 ภ, data as above except, "Kibwezi Forest, $2^{\circ} 27.95^{\prime} \mathrm{S}, 37^{\circ} 54.91$ 'E, 988 m, 11 Jan. 2000, A \& M Coll. \# 424, R.S. Copeland, ICIPE/USAID, r.f. Trichilia emetica"; “ठ Slide 5049”; "00196309" [MRAC]. Paratypes deposited in BMNH, MRAC, NMK, and USNM.
ReMARKs. Two female specimens missing abdomens (00196429 and 00196430) cluster together in the phenogram, apart from the main cluster of Blastobasis kenya (Figure 1); we treat as unassociated females, and they represent an unknown species.

ETYMOLOGY. The species epithet, kenya, is a noun in apposition recognizing the country of Kenya.

Distribution. Blastobasis kenya is found in habitats in the coastal lowlands, eastern midaltitudes (Kibwesi Forest, $988 \mathrm{~m}$ ), and the western highlands.

Hosts. Adenia sp. (Passifloraceae); Calophyllum inophyllum L. (Clusiaceae); Chrysophyllum viridifolium J. M. Wood \& Franks (Sapotaceae); Cola minor Brenan (Sterculiaceae); Deinbollia borbonica Scheff. (Sapindaceae); Diospyros kabuyeana F. White (Ebenaceae); Diphasia sp. (Rutaceae); Dovyalis macrocalyx (Oliv.) Warb. (Salicaceae); Dracaena mannii Baker (Dracaenaceae); Flacourtia indica (Burm. F.) Merr. (Salicaceae) Hirtella zanzibarica Oliv. ssp. zanzibarica (Chrysobalanaceae); Inhambanella henriquezii (Engl. \& Warb.) Dubard (Sapotaceae); Landolphia sp. (Apocynaceae); Lecaniodiscus fraxinifolius Baker ssp. scassellatii (Chiov.) Friis (Sapindaceae); Lepisanthes senegalensis (Poir.) Leenh. (Sapindaceae); Ludia mauritiana J. F. Gmel. (Salicaceae); Manilkara sansibarensis (Engl.) Dubard (Sapotaceae); Mimusops aedificatoria Mildbr. (Sapotaceae); Olea woodiana Knobl. ssp. disjuncta P. S. Green (Oleaceae); Oxyanthus goetzei K. Schum spp. keniensis Bridson ( $\mathrm{Ru}-$ biaceae); Rourea minor (Gaertn.) Alston (Connaraceae); Saba comorensis (Bojer) Pichon (Apocynaceae); Salacia elegans Oliv. (Celastraceae); Strychnos madagascariensis Poir., form e of Leeuwenburg (Loganiaceae); Terminalia catappa L. (Combretaceae); Toddalia asiatica (L.) Lam. (Rutaceae); Trichilia emetica Vahl (Meliaceae); Trilepisium madagascariense DC. (Moraceae); Vepris nobilis (Delile) Mziray (Rutaceae); Ximenia caffra Sond. (Olacaceae); and Xylopia sp. (Annonaceae).

\section{Blastobasis acirfa Adamski, new species}

$$
\text { FIGURES 11, 28, 57, MAP } 7
$$

Diagnosis. Blastobasis acirfa is similar to B. kenya and B. aynekiella but differs from the latter two species by having a wider gnathos, dorsoposterior margin of gnathos widely bidentate medially, and female with a funnel-shaped signum within the corpus bursae.

Description.

Head: Vertex and frontoclypeus with grayish brown scales tipped with pale grayish brown; outer and 
inner surfaces of labial palpus with basal segments brown and dark brown intermixed with pale grayish brown scales to near apical margin, terminal segment grayish brown intermixed with a few brown scales; scape of antenna yellowish brown, flagellum gray; first flagellomere dilated, forming a notchlike concavity between dilated part and flagellomeres 2-4 in male; proboscis grayish brown.

Thorax: Tegula and mesonotum brown on basal half, grayish brown scales tipped with pale grayish brown on distal half. Legs dark grayish brown, with a pale brown band near middle of all segments and apices of all segments and tarsomeres. Forewing (Figure 57) length 5.9-9.3 mm $(n=16)$, brownish gray intermixed with pale brownish gray scales, brownish gray scales tipped with pale brownish gray and brown scales; cell with three small, dark brown spots, one near midcell, two near distal end; marginal spots present or absent. Undersurface brown. Hindwing gray.

Abdomen: Male genitalia (Figure 11): Uncus narrowed apically from a slightly elevated base, acuminate apex, slightly recurved; gnathos narrow, dorsoposterior margin widely bidentate medially, shallowly grooved between dents; vinculum wide; juxta bandlike; valva divided; costa of upper part produced into a setose, digitate process, extending from apicoventral margin of proximal flange; proximal flange elongate, overlaid by dense microtrichiate membrane, narrowed distally, contiguous with digitate process; lower part of valva moderately wide, subventral area reflexed to apicoventral margin; apicoventral margin angular, produced into an acute, inwardly curved, acuminate process; process flattened on inner surface; diaphragma microtrichiate; aedeagus and sclerite of aedeagus abruptly curved near apical $1 / 3$; anellus with several conical setae; vesica near anellus with several hairlike cornuti. Female genitalia (Figure 28): Eighth tergum without a narrow, darkly pigmented streak on median longitudinal axis; membrane surrounding ostium moderately microtrichiate to lateral margin; seventh sternum darkly pigmented along posterolateral margins; ductus bursae shorter than ovipositor, with internally imbricate platelets on anterior half; inception of ductus seminalis slightly anterior to ostium; corpus bursae with a with a funnel-shaped signum.

Holotype. ô, "Kenya: Kakamega Forest, $0^{\circ} 13.66^{\prime} \mathrm{N}, 34^{\circ} 53.12^{\prime} \mathrm{E}, 15$ Aug. 2000, A \& M Coll. \# 817, R.S. Copeland, ICIPE/USAID, r.f. Olea welwitschii"; "Restrictions Apply, NMK/ICIPE, Agreement \# 5" [purple label]; “ $\widehat{O}$ Genitalia Slide by DA, No. 5048” [yellow label]; “USNM ENT 00196308” [barcode label] [NMK].
Paratypes ( $3 \hat{\delta}$, io + ). 1 으. same label data as holotype except, "coll. 11 Oct. 2000, R. Copeland, Lot 912, r.f. Mimusops bagshawei fruit"; "o Slide

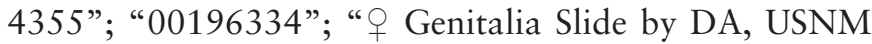
83397” [USNM]; 1 ô, data as above except, " $0{ }^{\circ} 13.14$ ' N, 3453.76'E, 14 Oct. 1999, Coll. \# 311, R.S. Copeland, ICIPE/USAID, r.f. Manilkara butugi"; "§ Slide 5050"; "001966310"; " ô Genitalia Slide by DA, USNM 83404" [USNM]; 3 \%, data as above except, "coll. 14 July 2000, R. Copeland, Coll. A \& M 752, r.f. Manilkara butugi fruit"; “o Slide 4345"; "00196327”; “ㅇ Genitalia Slide by DA, USNM 83398" [USNM]; "O Slide 4346"; "00196328” [BMNH]; “o Slide 4347”; "00196329”; “O Genitalia Slide by DA, USNM 83400” [USNM]; 2 o, data as above except, " $0^{\circ} 13.14{ }^{\prime} \mathrm{N}, 34^{\circ} 53.766^{\prime} \mathrm{E}$, coll. 15 Aug. 2000, R. Copeland, Coll. A \& M 820, r.f. Mimusops bagshawei fruit"; "O Slide 4353"; "00196332" [NMK] “o Slide 4359”; “00196337” [MRAC]; 1 §ૈ, data as above except, “ca. $0^{\circ} 14.13^{\prime} \mathrm{N}, 34^{\circ} 51.87^{\prime} \mathrm{E}$, coll. 14 Aug. 2000, R. Copeland, Coll. A \& M 821, r.f.

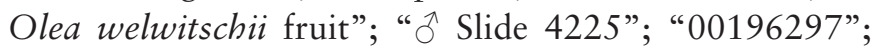
“ 7 Genitalia Slide by DA, USNM 83403” [USNM]; 1 ${ }^{\top}$, data as above except, “ca. $0^{\circ} 12.34^{\prime} \mathrm{N}, 34^{\circ} 53.57^{\prime} \mathrm{E}$, coll. 2 June 2000, R. Copeland, Coll. A \& M 713, r.f. Tiliacora funifera fruit"; "O Slide 4228"; "00196299" $[\mathrm{BMNH}] ; 1$ 엉 data as above except, “ca. $0^{\circ} 11.90^{\prime} \mathrm{N}$, 34 52.68'E, coll. 25 Feb. 2000, R. Copeland, Coll. A \& M 534, r.f. Synsepalum cerasiferum fruit"; “o Slide 4356"; "00196335”; “o Genitalia Slide by DA, USNM 83399” [USNM]; 1 + , data as above except, “ $0{ }^{\circ} 14.16{ }^{\prime} \mathrm{N}$, 3451.82'E” "26 April 2001, A \& M Coll. \# 1215, R.S. Copeland, ICIPE/USAID, r.f. Prunus africana"; "O Slide

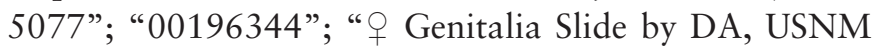
83401" [USNM]; 1 \% , data as above except, "Western Prov., Kakamega Forest, $0^{\circ} 14.13^{\prime} \mathrm{N}, 34^{\circ} 51.87^{\prime} \mathrm{E}$, on Olea welwitschii, Oleaceae, 14.VIII.2000, R. Copeland, A \& M 821”; “ㅇ Slide 5110”; “00196371”; “ Genitalia Slide by DA, USNM 83402" [USNM]; 1 \% data as above except, "Coast Prov., Kaya Kinondo, $4^{\circ} 23.71$ 'S, $39^{\circ} 32.84^{\prime} \mathrm{E}$, on Olea woodiana subsp. disjuncta, Oleaceae, 20.VII.2000, R. Copeland, A \& M 763”; “o Slide 5095"; "00196359" [NMK]. Paratypes deposited in BMNH, MRAC, NMK, and USNM.

REMARKs. Four specimens $(2 \hat{\jmath}, 2$ o ) from Shimba Hills diverge from the main cluster of Blastobasis acirfa in the phenogram (Figure 1). Three of these specimens are not treated in the taxonomic section because their identities are uncertain due to their poor condition. Their label data are as follows: $1 \hat{\gamma}$, "KENYA: Coast Province, Shimba Hills, $4^{\circ} 10.659^{\prime}$ S, 39²6.677'E, 


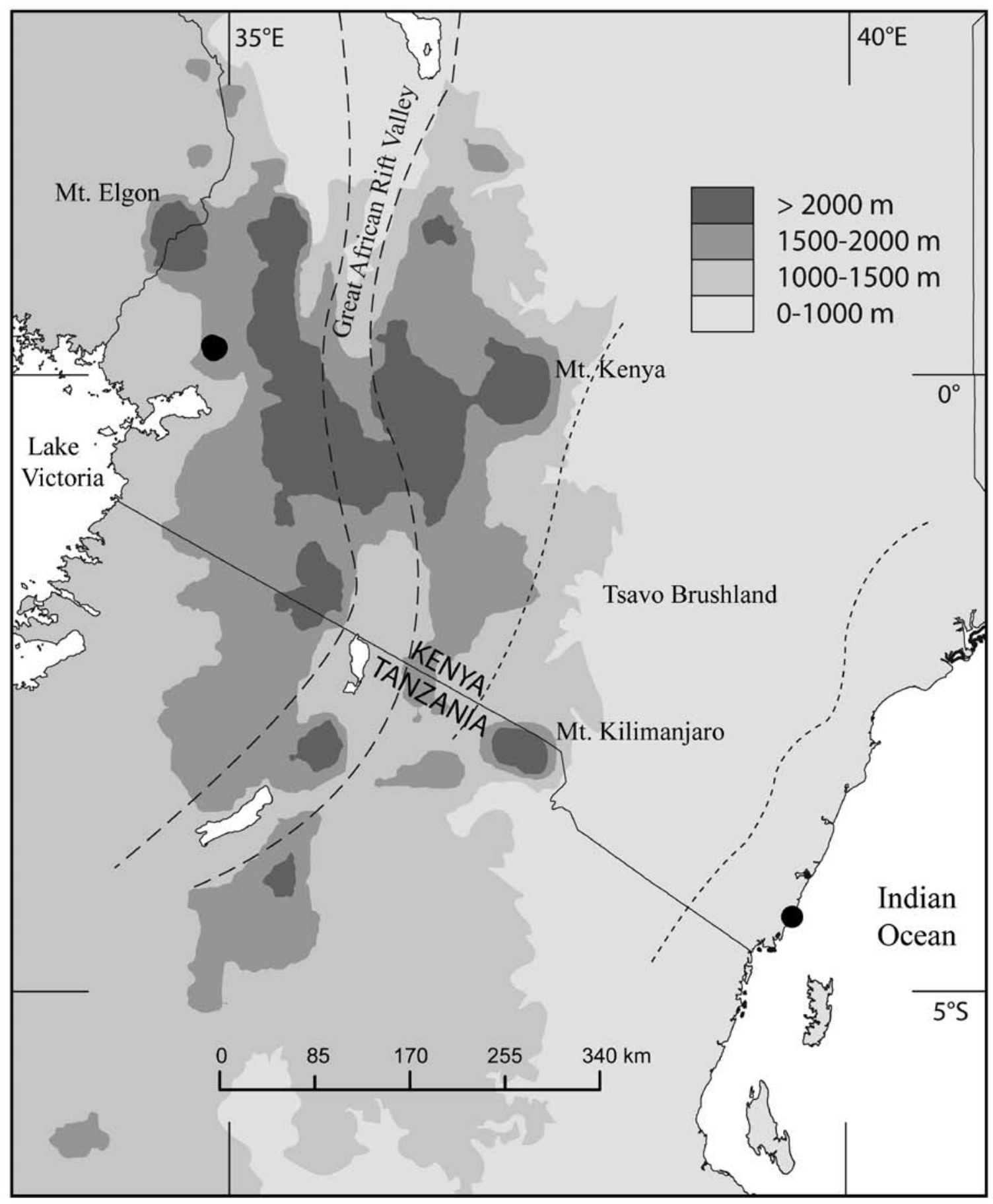

MAP 7. Distribution of Blastobasis acirfa.

24.IV.2002, R.S. Copeland"; "ex fruits, Saba comorensis, ICIPE/USAID, Coll. \# 1901”; “ $\widehat{O}$ Slide 5062”; "00196314" [NMK]; 1 क, "Shimba Hills, 4¹4.27'S, 39²3.74'E, 22 Apr. 2002, R.S. Copeland”; “ex fruits Mimusops aedificatoria, ICIPE/USAID, Coll. \# 1909”;
“00196410" [NMK]; 1 +, "Shimba Hills, 389 m, $4^{\circ} 15.42^{\prime}$ S, 39²2.96'E, 9 Aug. 2002, A \& M Coll. \# 2139, R.S. Copeland, ICIPE/USAID, r.f. Hirtella zanzibarica fruit”; “o Slide 5121”; “00196381” [NMK]. The fourth specimen in the divergent cluster ( 0 USNM 
00196356, DA 5092) has been identified as Blastobasis chuka and is treated below.

ETYMOLOGY. The species epithet, acirfa, is taken from the name of the continent in which this species is known to occur, but spelled backward.

Distribution. Blastobasis acirfa has a disjunct distribution; it is recorded from habitats in the coastal lowlands and western highlands.

Hosts. Manilkara butugi Chiov. (Sapotaceae); Mimusops bagshawei S. Moore (Sapotaceae); Olea welwitschii (Knobl.) Gilg \& Schellenb. (Oleaceae); Olea woodiana Knobl. ssp. disjuncta P. S. Green (Oleaceae); Prunus africana (Hook.f.) Kalkman (Rosaceae); Synsepalum cerasiferum (Welw.) T. D. Penn. (Sapotaceae); Tiliacora funifera (Miers.) Oliv. (Menispermaceae).

\section{Blastobasis aynekiella Adamski, new species}

\section{FIGURES $12,29,56$, MAP 8}

Diagnosis. Blastobasis aynekiella is similar to $B$. kenya and B. acirfa but differs from the latter two species by having the dorsoposterior margin of the gnathos more anterior to the base of the uncus, an aedeagus that is serpentine shaped, and female with two to three irregular rows of spinelike setae on the seventh tergum.

Description.

Head: Vertex and frontoclypeus with grayish brown scales tipped with pale grayish brown; outer and inner surfaces of labial palpus with basal segments brown and dark brown scales intermixed with pale grayish brown scales to near apical margin, terminal segment grayish brown intermixed with few brown scales; scape yellowish brown, flagellum gray; first flagellomere of antenna dilated, forming a notch between dilation and flagellomeres $2-4$ in male; proboscis grayish brown.

Thorax: Tegula and mesonotum with brown scales tipped with pale brown. Legs dark brown with a pale brown band near middle of segments and apices of all segments and tarsomeres. Forewing (Figure 56) length 6.9-8.3 mm $(n=8)$, yellowish brown intermixed with yellowish brown scales tipped with pale yellowish brown and brown scales; submedian fascia faint; cell with three small, dark brown spots, one near midcell, two near distal end; marginal spots present. Undersurface brown. Hindwing gray.

Abdomen: Male genitalia (Figure 12): Uncus abruptly narrowed from broadened base, subapically curved ventrally, gradually narrowed to an acuminate apex; gnathos narrow, dorsoposterior margin bidentate medially; vinculum wide; juxta bandlike; valva divided; costa of upper part of valva produced into a setose, digitate process; lower part of valva moderately wide, subventral area reflexed to apicoventral margin; apicoventral margin angular, produced into an inwardly curved, acuminate process; process with a flattened inner surface; proximal flange elongate, apicoventral margin rounded distoventrally, overlaid with dense microtrichiate membrane, narrowed distally, contiguous with digitate process; diaphragma microtrichiate; aedeagus and sclerite of aedeagus serpentine shaped; anellus bearing several conical setae throughout length. Female genitalia (Figure 29): Eighth tergum without a narrow, darkly pigmented streak on median longitudinal axis; membrane surrounding ostium moderately microtrichiate to lateral margin; seventh tergum with two to three irregular rows of spinelike setae on posterior end; ductus bursae shorter than ovipositor, with internal rows of imbricate platelets on anterior half; inception of ductus seminalis slightly anterior to ostium; corpus bursae with a moderately large capitulate signum with a hornlike process.

Holotype. đ, "Kenya: Kakamega Forest, $0^{\circ} 14.16^{\prime} \mathrm{N}, 34^{\circ} 51.82^{\prime} \mathrm{E}, 26$ April 2001, A \& M Coll. \# 1215, R.S. Copeland, ICIPE/USAID, r.f. Prunus africana"; "Restrictions Apply, NMK/ICIPE, Agreement \# 5" [purple label]; “ $\widehat{O}$ Genitalia Slide by DA, No. 5045” [yellow label]; “USNM ENT 00196306" [barcode label] [NMK].

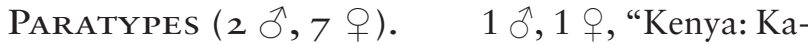
kamega Forest, ca. $0^{\circ} 14.13$ 'N, 3451.87'E, Coll. 14 Aug. 2000, R. Copeland, Lot 821, r.f. Olea welwitschii fruit";

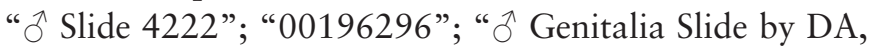
USNM 83405” [USNM]; “o Slide 4350”; “00196330” [NMK]; 1 , data as above except, "31 Oct. 2001, A \& M Coll. \# 1506, R.S. Copeland; ICIPE/USAID, r.f. Mimusops bagshawei”; "o Slide 4915”; "00196321”; “o Genitalia Slide by DA, USNM 83448" [USNM]; 1 , data as above except, “ $0^{\circ} 13.10^{\prime} \mathrm{N}, 34^{\circ} 54.06$ 'E, 31 Oct. 2001, A \& M Coll. 1499, R.S. Copeland, ICIPE/USAID, r.f. Prunus africana"; “00196420” [USNM]; 1 + , “0¹3.44'N, 3453.44'E, coll. 2 May 2000, R. Copeland, Coll. A \& M 651, r.f. Tiliacora

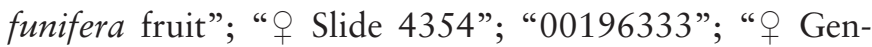
italia Slide by DA, USNM 83406" [USNM]; 1 \%, data as above except, " $0^{\circ} 13.14$ ' $\mathrm{N}, 34^{\circ} 53.76^{\prime} \mathrm{E}$, coll. 16 Dec. 1999, R. Copeland, Coll. A \& M 390, r.f. Chrysophyllum albidum fruit”; “ O Slide 4227”; “00196298” [BMNH]; 1 o, “Kenya: Western Kakamega Forest on Prunus africana, $0^{\circ} 14.13^{\prime} \mathrm{N}, 34^{\circ} 51.87^{\prime} \mathrm{E}, 29 . \mathrm{III} .2000$, R. Copeland, A \& M

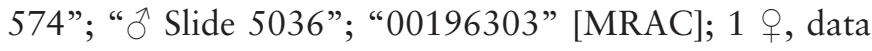
as above except, " $0^{\circ} 13.14$ ' $\mathrm{N}, 34^{\circ} 54.14$ 'E; Coll. 13 Apr. 1999, R. Copeland, Lot 67, r.f. Prunus africana fruit";

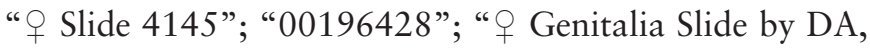




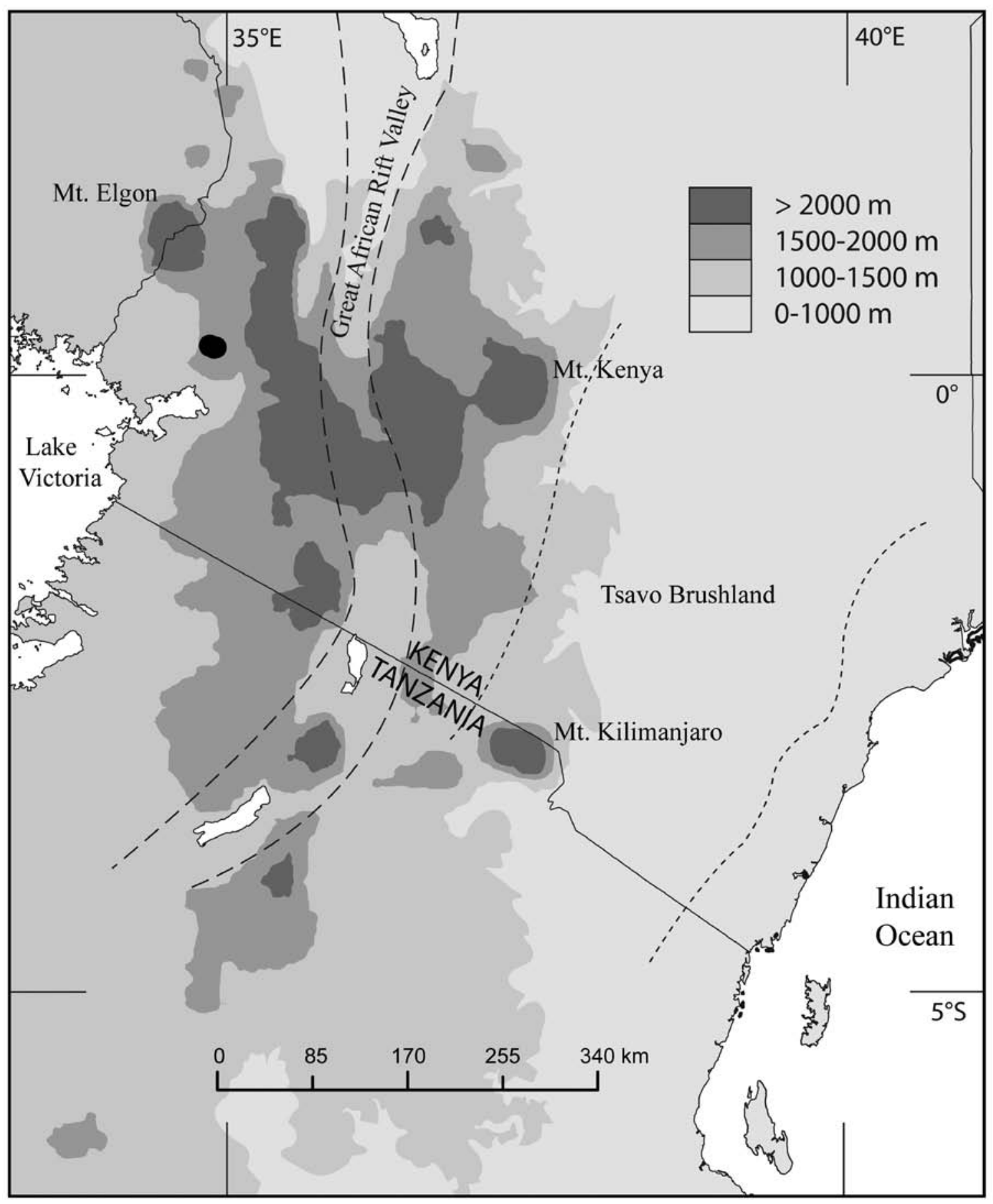

MAP 8. Distribution of Blastobasis aynekiella.

USNM 83407” [USNM]; 1 ㅇ, “0¹3.44'N, 3453.44'E, 2.V.2000, R. Copeland, A \& M 658”; “우 Slide 5078”; "00196345" [NMK]. Paratypes deposited in BMNH, MRAC, NMK, and USNM.

ETYMOLOGY. The species epithet, aynekiella, is taken from the name of the country in which this species is known to occur, but spelled backward, with the Latin suffix -iella (meaning small) added.

Distribution. Blastobasis aynekiella is known only from the western highlands of the Kakamega Forest.

Hosts. Chrysophyllum albidum G. Don (Sapotaceae); Mimusops bagshawei S. Moore (Sapotaceae); 
Olea welwitschii (Knobl.) Gilg \& Schellenb. (Oleaceae); Prunus africana (Hook.f.) Kalkman (Rosaceae); Tiliacora funifera (Miers.) Oliv. (Menispermaceae).

\section{Blastobasis catappaella Adamski, new species}

FIGURES 13, 35, 59, MAP 9

Diagnosis. Blastobasis catappaella is similar to Blastobasis kenya, B. acirfa, and B. aynekiella in wing pattern but differs in having a narrower base of the uncus, an abruptly narrowed basiventral margin of the proximal flange, a narrower base of the digitate process of the upper part of the valva, dorsal strut on the dorsoanterior part of the tegumen, and female signum with a spine asymmetrically located on base.

DESCRIPTION.

Head: Vertex and frontoclypeus pale brown; labial palpus missing; scape of antenna pale brown, flagellum pale gray; male first flagellomere dilated, forming a notch adjacent to flagellomeres 2-4; proboscis pale brown.

Thorax: Tegula and mesonotum brown basally, pale brown distally. Legs brown with a pale brown band near middle of all segments and apices of all segments and tarsomeres. Forewing (Figure 59) length $4.0 \mathrm{~mm}$ $(n=1)$, pale brown intermixed with brown and a few reddish brown and dark brown scales; middle pale brown intermixed with a few reddish brown scales; median fascia present or absent; costal area and area beyond cell brown intermixed with a few pale brown scales; cell with three dark brown spots, one near middle, two on distal end near crossvein; dark brown marginal spots present. Undersurface brown. Hindwing pale brown, gradually darkening to apex.

Abdomen: Male genitalia (Figure 13): Uncus narrowed near midlength, slightly widened distally; gnathos wide, dorsoposterior margin bidentate medially; dorsal strut present; vinculum wide; juxta bandlike; valva divided; costa of dorsal part produced into a setose, digitate process; lower part of valva moderately wide, subventral area reflexed to apicoventral margin; apicoventral margin angular, produced into an inwardly curved, acuminate process; process flattened on inner surface; proximal flange abruptly emarginate basiventrally, overlaid by a dense microtrichiate membrane; contiguous with digitate process; diaphragm sparsely microtrichiate; aedeagus and aedeagal sclerite broadly curved; anellus elongate, bearing several conical setae. Female genitalia (Figure 35): Eighth tergum with a narrow, elongate, and darkly pigmented streak on median longitudinal axis; membrane surrounding ostium sparsely microtrichiate to lateral margin; ductus bursae shorter than ovipositor, with internal, imbricate platelets on anterior $2 / 3$; inception of ductus seminalis slightly anterior to ostium; corpus bursae with a signum with a short spinelike process asymmetrically placed on an elongate base.

Holotype. $\hat{O}$, “Kenya: Laikipia Plateau, Mpala Research Centre, $0.293^{\circ} \mathrm{N}, 36.899^{\circ} \mathrm{E}, 1650 \mathrm{~m}, 16-$ 19 June 2003, S.E. Miller"; "Restrictions Apply, NMK/ ICIPE, Agreement \# 5" [purple label]; “ $\widehat{o}$ Genitalia Slide by DA, no. 5071" [green label]; "USNM ENT 00196867" [barcode label] [NMK].

Paratypes (9 ô, 4 우). 4 ô, "Kenya: Laikipia Plateau, Mpala Research Centre, $0.293^{\circ} \mathrm{N}, 36.899^{\circ} \mathrm{E}$, 1650 m, 23-26 Dec. 1999, S.E. Miller \& T.M. Kuklenski”; “へ Slide 4140"; "00194978”; “ đ Genitalia Slide by DA, USNM 83408” [USNM]; “へ Slide 4141”; “00194942”; “ 0 Genitalia Slide by DA, USNM 83410" [USNM]; “ 0

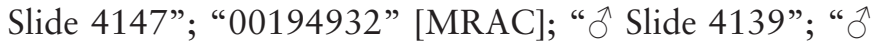
Genitalia Slide by DA, USNM 83411" [USNM]; 2 \%, 2 ㅇ, "16-19 June 2003”; “S.E. Miller”; “ㅇ Slide 5072”; "00196868"; "ᄋ Genitalia Slide by DA, USNM 83412" [USNM]; “00196873” [USNM]; "00196874” [USNM]; “00196875” [USNM]; 1 స, 1 क, “6-9 Dec. 2002”; “ठ Slide 5073"; "00196869"; “خ Genitalia Slide by DA,

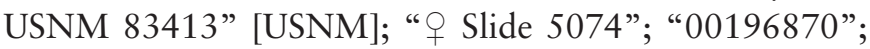
“o Genitalia Slide by DA, USNM 83414” [USNM]; 1 o, 1 o, "19-21 May 1999”; “ O Slide 4146”; "00196871” [BMNH]; “o Slide 4143”; “00192236”; “ Genitalia Slide by DA, USNM 83415" [USNM]; 1 ${ }^{\lambda}$, "Kenya: Kaya Kinondo, ca. $4^{\circ} 23.71$ 'S, $39^{\circ} 32.84^{\prime}$ 'E, Coll[ected] 20 July 2000, R. Copeland, Kip - 654, r.f. Terminalia catappa fruit"; "Slide 4339"; "00196866" [NMK]. Paratypes deposited in BMNH, MRAC, NMK, and USNM.

ETyMology. The specific epithet, catappaella, is derived from the species name of the host.

Distribution. Blastobasis catappaella is known from habitats along the southeastern coast and in the xeric central highlands.

Host. Fruits of Terminalia catappa Linnaeus (Combretaceae).

\section{Blastobasis glauconotata Adamski, new species}

FIGURES 14, 31, 46, MAP 10

Diagnosis. Blastobasis glauconotata is most similar to B. chuka, but it differs from the latter by having a slightly narrower uncus, a wider inner surface of the acuminate process of the lower part of the valva, a narrower microtrichiate area of the valva, a shorter aedeagus, a broader anellus of the aedeagus, and female with a ductus bursae that is $2 / 3$ the length of the ovipositor. 


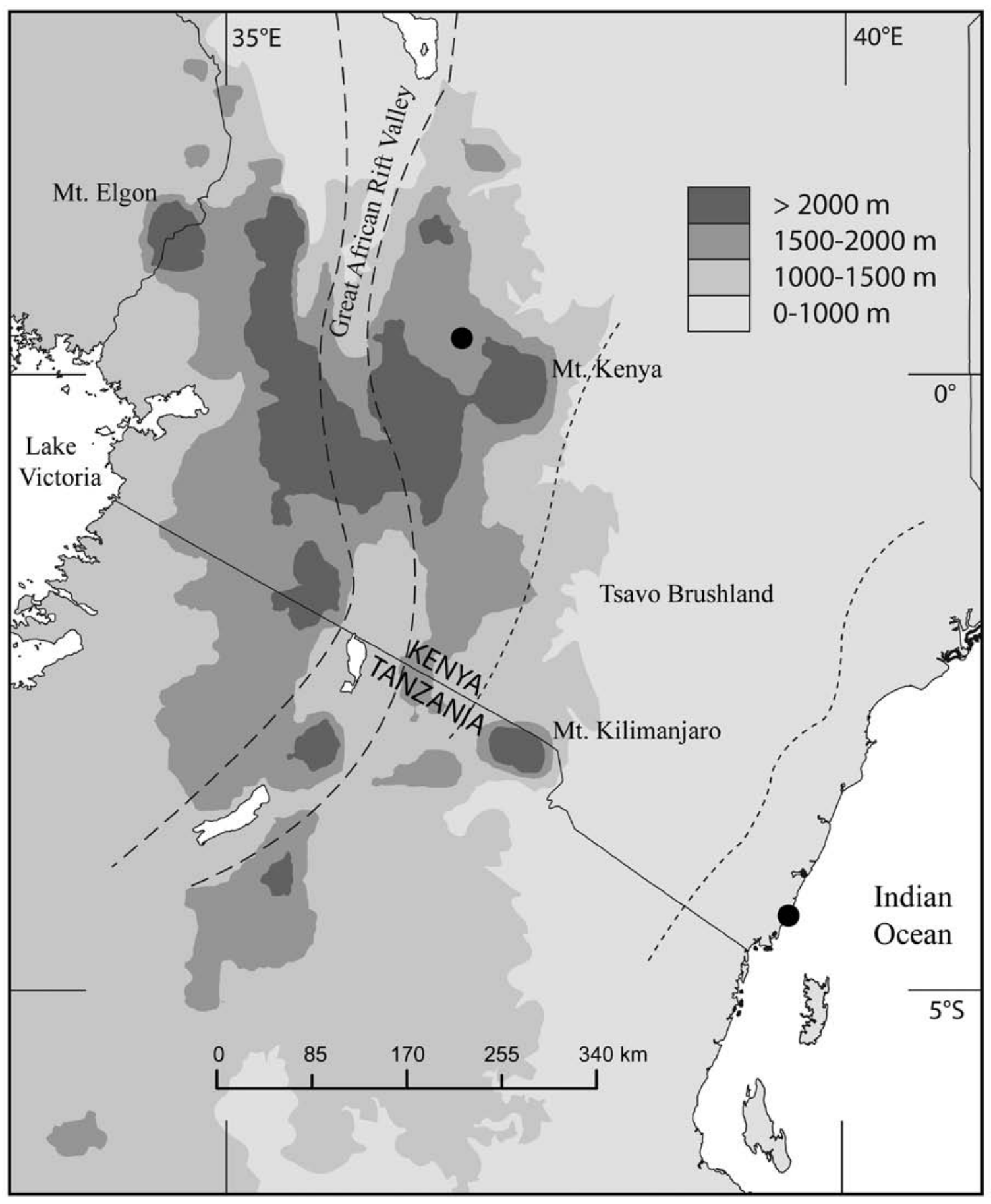

MAP 9. Distribution of Blastobasis catappaella.

\section{DESCRIPTION.}

Head: Vertex and frontoclypeus with scales grayish brown tipped with pale grayish brown; labial palpus with outer surface of segments I and II grayish brown intermixed with few pale grayish brown scales to apical margin, segment III grayish brown; inner surface as above except, segment III darker; scape and flagellum of antenna pale grayish brown; male first flagellomere dilated, forming a notch between itself and flagellomeres 2-4; proboscis pale grayish brown. 
Thorax: Tegula and mesonotum brown basally, grayish brown distally. Legs brown with a pale grayish brown band near middle of all segments and apices of all segments and tarsomeres. Forewing (Figure 46) length 6.8$9.1 \mathrm{~mm}(n=23)$, grayish brown intermixed with a few pale grayish brown and brown scales or basal $1 / 3$ pale grayish brown, distal $2 / 3$ slightly darker; four small brown spots present; three spots within cell, one near middle and two on distal end near crossvein; one spot posterior to midcell spot on CuP; marginal spots dark gray or faint. Undersurface grayish brown. Hindwing pale grayish brown basally, gradually darkening to apex.

Abdomen: Male genitalia (Figure 14): Uncus broadly curved ventrally from a slightly widened base, apex rounded narrowly; gnathos narrow, dorsoposterior margin bidentate medially; dorsal strut present; vinculum wide; juxta bandlike; valva divided; costa of upper part produced into a setose, digitate process; lower part of valva moderately wide, subventral area reflexed to apicoventral margin; apicoventral margin slightly angular, produced into an inwardly curved process; process broad, inner surface flattened; proximal flange elongate, overlaid by dense microtrichiate membrane, narrowed distally, contiguous with digitate process; aedeagus and sclerite of aedeagus slightly curved slightly above midlength; anellus broadly rounded apically, bearing several conical setae. Female genitalia (Figure 31): Eighth tergum with a narrow, darkly pigmented streak along median longitudinal axis; ostium slightly posterior to seventh segment; membrane surrounding ostium microtrichiate; medioposterior margin of seventh sternum slightly emarginate medially; inception of ductus seminalis slightly anterior to ostium; ductus bursae about $2 / 3$ length of ovipositor, with internal imbricate platelets on anterior half; corpus bursae slightly elongate; signum with a spinelike process arising from middle of a slightly elevated base.

Holotype. $\sigma^{\lambda}$, "Kenya: Chuka Forest, $0^{\circ} 21.06$ 'S, 37³5.80'E, $1600 \mathrm{~m}$, 20 Jan. 2003, A \& M Coll[ection] \# 2372, R.S. Copeland; ICIPE/USAID, r.f. Prunus africana"; "Restrictions Apply, NMK/ICIPE, Agreement \# 5" [purple label]; “ $\bigcirc$ Genitalia Slide by D. Adamski, No. 5023" [yellow label]; "USNM ENT 00196876" [barcode label] [NMK].

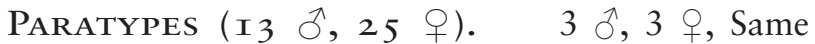
label data as above except, " $\bigcirc$ Slide 5024"; "00196882"; " $\widehat{O}$ Genitalia Slide by DA, USNM 83421" [USNM]; “ $\widehat{ }$ " Slide 5026"; "00196883"; "Ô Genitalia Slide by DA, USNM 83430” [USNM]; “ ^ Slide 5027”; “00196884”; " $\widehat{0}$ Genitalia Slide by DA, USNM 83416" [USNM]; "ㅇ Slide 5022"; "00196877”; “ $\circ$ Genitalia Slide by DA, USNM 83417” [USNM]; “q Slide 5028”; “00196878”; “o Genitalia Slide by DA, USNM 83418” [USNM]; “ㅇ Slide 5030"; “00196880"; “ㅇ Genitalia Slide by DA, USNM 83419" [USNM]; 1 ô, label data as above except, "1576 [m], 0²1.237'S, 37³6.184'E, Coll. \# 2365, r.f. Toddalia asiatica"; " 0 Slide 5017"; "00196386"; " 0 - Genitalia Slide by DA, USNM 83420" [USNM]; 1 ô, “Mount Elgon, $2452 \mathrm{~m}, 1^{\circ} 01.730^{\prime} \mathrm{N}, 34^{\circ} 45.280^{\prime} \mathrm{E}$, 29 Jan. 2003, Coll. \# 2408, r.f. Ekebergia capensis"; “ Slide 5019"; "00196387" [BMNH]; 1 ô, "Ololua Forest, ca. $1^{\circ} 21.52^{\prime} \mathrm{S}, 36^{\circ} 42.33^{\prime} \mathrm{E}$, Coll. 16 July 1999, Coll.

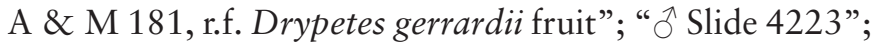

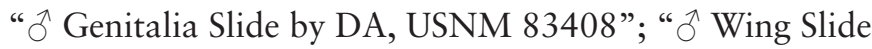
by DA, USNM 83422”; “00196318” [USNM]; 1 , data as above except, "8 Apr. 2000, Lot 603, r.f. Solanum anguivi"; "o Slide 5094"; "00196358”; "o Genita-

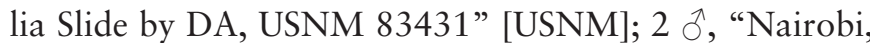
$1^{\circ} 16.44^{\prime}$ 'S, 36²48.83'E, 3 June 2001, A \& M Coll. \# 1290 [\# 1271, for second specimen], r.f. Afrocarpus falcatus";

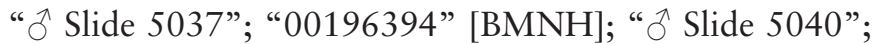
"00196395" [NMK]; 1 क , data as above except, "21 April 2001, A \& M Coll. \# 1190, r.f. Afrocarpus falcatus"; "00196425" [USNM]; 1 क, data as above except, "19 Oct. 2001, A \& M Coll. \# 1450”; “00196426” [USNM]; 1 q, data as above except, "30 Mar. 2001, A \& M Coll. 1129"; "Slide 5106"; "00196367"; 1 q, data as above except, "29 Jan. 2001, A \& M Coll. \# 972”; “00196422”; “o Genitalia Slide by DA, USNM 83423” [USNM]; 1 + , data as above except, "29 Jan. 2001, A \& M Coll. \# 972”; “00196422” [USNM]; 1 ô, 3 q, “Central Prov. Njukini Forest, $0^{\circ} 31.15^{\prime}$ 'S, 37²5.19'E, 24 July 2001, A \& M Coll. \# 1397, r.f. Chaetacme aristata"; "Ô Slide 5041"; "00196396" [NMK]; "o Slide 5116"; “00196376" [MRAC]; “o Slide 5117”; “00196377” [NMK]; “00196423” [USNM]; 1 ô, "Ngong R[oa]d Forest, $1^{\circ} 18.82^{\prime} \mathrm{S}, 36^{\circ} 43.88 \mathrm{E}, 6$ April 2001, A \& M Coll. \# 1151, r.f. Warburgia ugandensis”; “ $\mathrm{O}$ Slide 5046”; "00196397” [MRAC]; 2 + , data as above except, "6 April 2001, A \& M Coll. \# 1156, r.f. Schrebera alata”; “ㅇ Slide

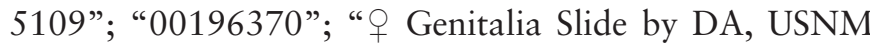
83432” [USNM]; “00196412” [USNM]; 1 ภे, "A \& M 1157, r.f., fruit Vepris simplicifolia"; "त Slide 5059"; "00196401"; " ô Genitalia Slide by DA, USNM 83424" [USNM]; 1 , , data as above except, "A \& M Coll. \# 1153, r.f. Mimusops kummel”; “o Slide 5099”; "00196363” [MRAC]; 1 9, data as above except, " 6 April 2001, Coll. A \& M 1151, r.f. Warburgia ugandensis"; “o Slide 5096”; "00196360"; "ᄋ Genitalia Slide by DA, USNM 83425” [USNM]; 2 , , data as above except, "1829 m, A \& M Coll. \# 1149, r.f. Elaeodendron buchananii"; " + Slide 5111”; “00196372” [BMNH]; “00196421” [USNM]; 2 


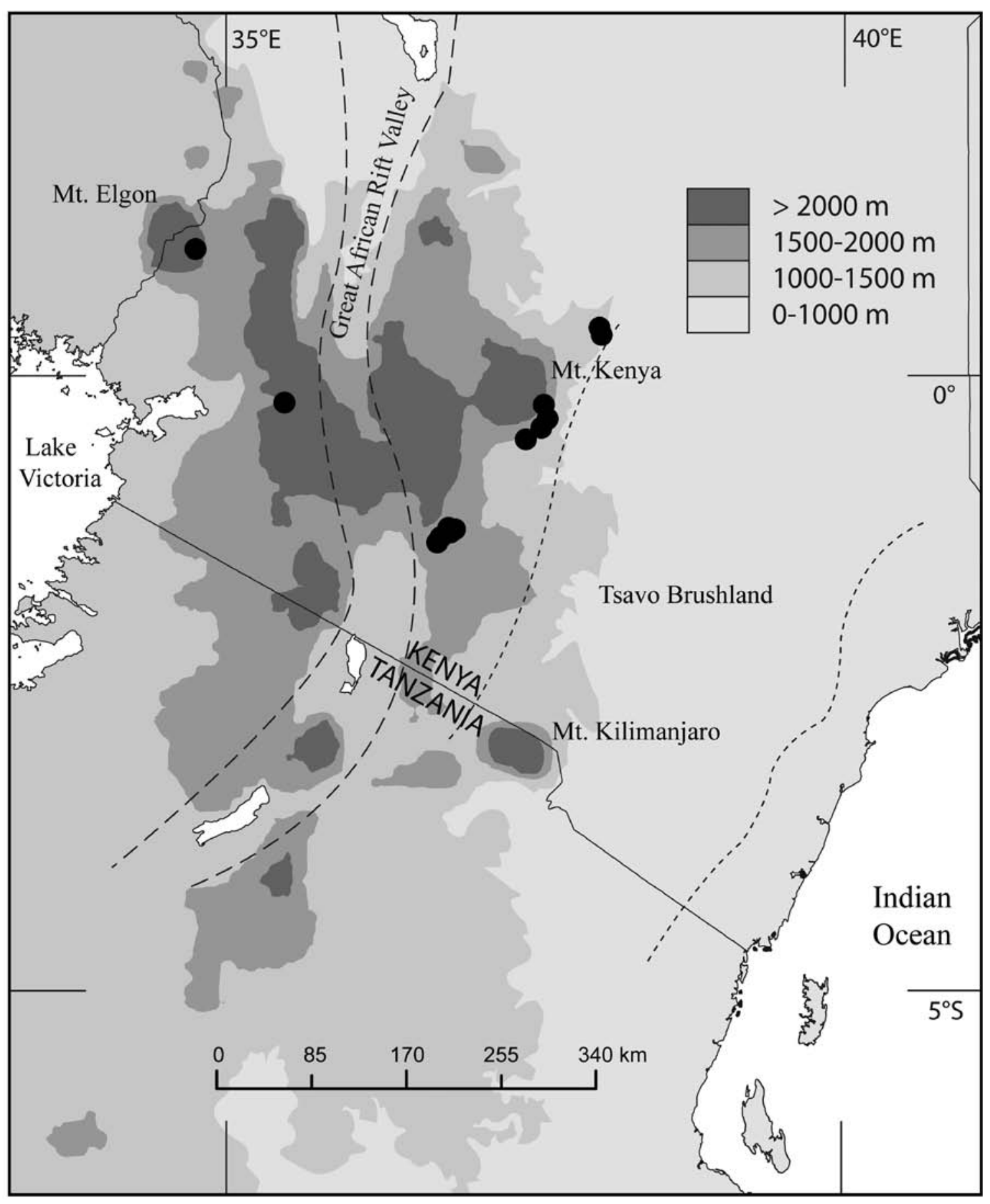

MAP 10. Distribution of Blastobasis glauconotata.

đ, “Karura Forest, $1759 \mathrm{~m}, \mathrm{ca} .1^{\circ} 14.28^{\prime} \mathrm{S}, 36^{\circ} 47.66$ 'E, 9 Apr. 2001, A \& M Coll. \# 1162, r.f. fruit, Schrebera alata"; " Oे Slide 5056"; "00196399"; "ठ Genitalia Slide by DA, USNM 83446” [USNM]; “ 7 Slide 5060"; "00196402” [BMNH]; 2 ㅇ, data as above except, “1655 m, 1¹4.95'S,
3650.83'E, 26 April 2004, A \& M Coll. \# 2778”; “r.f. Vepris trichocarpa"; "00196432" [USNM]; "00196434” [USNM]; 1 +, "Ngala Forest, lower portion, $1230 \mathrm{~m}$, $0^{\circ} 19.87^{\prime} \mathrm{N}, 38^{\circ} 01.96^{\prime} \mathrm{E}, 27$ May 2004, A \& M Coll. \# 2918, R.S. Copeland, ICIPE/USAID”; “r.f. Strychnos 
mitis"; "00196433" [USNM]; 1 + , data as above except, “upper portion, $1420 \mathrm{~m}, 0^{\circ} 23.36^{\prime} \mathrm{N}, 38^{\circ} 00.88^{\prime} \mathrm{E}, 10$ Sept. 2003, A \& M Coll. \# 2571"; "r.f. Rawsonia lucida"; "00196431" [USNM]; 1 +, "Kirimiri Forest, 1745 m, 0 25.45'S, 37³2.71'E, 8 Nov. 2001, A \& M Coll. \# 1510, RS Copeland, ICIPE/USAID, r.f. Cussonia spicata"; "o Slide 5084"; "00196348”; "o Genitalia Slide by DA, USNM 83428” [USNM]; 1 q, "City Park Forest, $1697 \mathrm{~m}, 1^{\circ} 15.61^{\prime} \mathrm{S}, 36^{\circ} 49.76^{\prime} \mathrm{E}, 19$ April 2001, A \& M Coll. \# 1183, RS Copeland, ICIPE/USAID, r.f. Strychnos mitis"; "o Slide 5088"; "00196352"; "o Genitalia Slide by DA, USNM 83429" [USNM]; 1 + , "Mau Forest, $2175 \mathrm{~m}, 0^{\circ} 14.13$ 'S, 3532.94'E, 3 Feb. 2003, A \& M Coll. 2459, R.S. Copeland, ICIPE/USAID, r.f. Vepris nobilis"; "o Slide 5021”; “00196892”; “o Genitalia Slide by DA, USNM 83427” [USNM]. Paratypes deposited in BMNH, MRAC, NMK, and USNM.

ETYMOLOGY. The species epithet, glauconotata, is a compound word derived from the Latin, glauco, meaning gray, and nota, meaning spot, referring to the dark gray marginal spots on the distal third of the forewing.

Distribution. Blastobasis glanconotata is known from habitats in the central and western highlands and in the central midaltitudes of Ngaia Forest at $1230 \mathrm{~m}$.

Hosts. Fruits of Afrocarpus falcatus (Thunb.) C. N. Page (Podocarpaceae); Chaetacme aristata Planch. (Ulmaceae); Cussonia spicata Thunb. (Araliaceae); Drypetes gerrardii Hutch. (Euphorbiaceae); Elaeodendron buchananii (Loes.) Loes. (Celastraceae); Ekebergia capensis Sparrm. (Meliaceae); Mimusops kummel A. DC. (Sapotaceae); Prunus africana (Hook.f.) Kalkman (Rosaceae); Rawsonia lucida Harv. \& Sond. (Achariaceae); Schrebera alata (Hochst.) Welw. (Oleaceae); Solanum anguivi Lam. (Solanaceae); Stychnos mitis S. Moore (Loganiaceae); Toddalia asiatica (L.) Lam. (Rutaceae); Vepris nobilis (Delile) Mziray (Rutaceae); Vepris simplicifolia (Engl.) Mziray (Rutaceae); Vepris trichocarpa (Engl.) Mziray (Rutaceae); Warburgia ugandensis Sprague (Canellaceae).

\section{Blastobasis chuka Adamski, new species}

\section{FIGURES 16, 36, 44, MAP 11}

Diagnosis. Blastobasis chuka is most similar to B. glauconotata but differs from the latter by having a more angular digitate process of the upper part of the valva, a wider microtrichiate part of the lower part of the valva, a slightly longer aedeagus, a more acutely curved aedeagus, and female with an antrum that is cuplike.

\section{Description.}

Head: Vertex and frontoclypeus with scales brownish gray tipped with pale brown; labial palpus with outer surface of segments I and II brown intermixed with pale brownish gray scales to apical margin, segment III pale brown; inner surface pale brown; scape of antenna pale brownish gray, flagellum pale gray; male first flagellomere dilated, forming a notch between itself and flagellomeres 2-4. Proboscis pale brownish gray.

Thorax: Tegula and mesonotum brown intermixed with pale brown scales. Legs brown with a pale brown band on apices of all segments and tarsomeres. Forewing (Figure 44) length $6.3-8.2 \mathrm{~mm}(n=6)$, submedian fascia faint, complete, chevron shaped; basal $1 / 3$ from base to submedian fascia pale brown intermixed with a few brown scales, distal 2/3 from submedian fascia to margin brown intermixed with a few pale brown scales; cell with two faint, small spots on distal end near crossvein; submarginal spots faint. Undersurface brown. Hindwing pale gray.

Abdomen: Male genitalia (Figure 16): Uncus wide basally, narrowing apically, acutely curved subapically, apex rounded narrowly; gnathos narrow, dorsoventral margin shallowly bidentate medially; dorsal strut present; vinculum wide; juxta bandlike; valva divided; costa of upper part produced into a setose, digitate process; lower part of valva moderately wide, subventral area reflexed to apicoventral margin, apicoventral margin angular, produced into an inwardly curved, acuminate process; process flattened on inner margin; proximal flange elongate, apicoventral margin angular, overlaid by dense microtrichiate, contiguous with digitate process; aedeagus and sclerite of aedeagus subapically acutely curved near apical $1 / 3$; anellus elongate, bearing several conical setae. Female genitalia (Figure 36): Eighth tergum with a narrow, darkly pigmented streak on median longitudinal axis; ostium slightly posterior to seventh segment; antrum cuplike; membrane surrounding ostium densely microtrichiate to lateral margin; ductus bursae longer than ovipositor, with imbricate platelets on anterior half; inception of ductus seminalis slightly anterior to ostium; anterior part of corpus bursae with a signum bearing a spinelike process arising from an elongate base.

Holotype. Oे, "Chuka Forest, $0^{\circ} 21.06$ 'S, 37³5.80'E; 1600 m, 20 Jan. 2003; A \& M Coll[ection] \# 2372, R.S. Copeland; ICIPE/USAID, r.f. Prunus africana"; "Restrictions Apply, NMK/ICIPE, Agreement \# 5" [purple label]; " $\widehat{o}$ Genitalia Slide by D. Adamski, No. 5025" [yellow label]; “USNM ENT 00196885” [barcode label] [NMK].

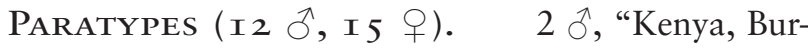
guret Forest, $0^{\circ} 07.208^{\prime} \mathrm{S}, 37^{\circ} 05.147^{\prime} \mathrm{E}, 23$ May 2002, 


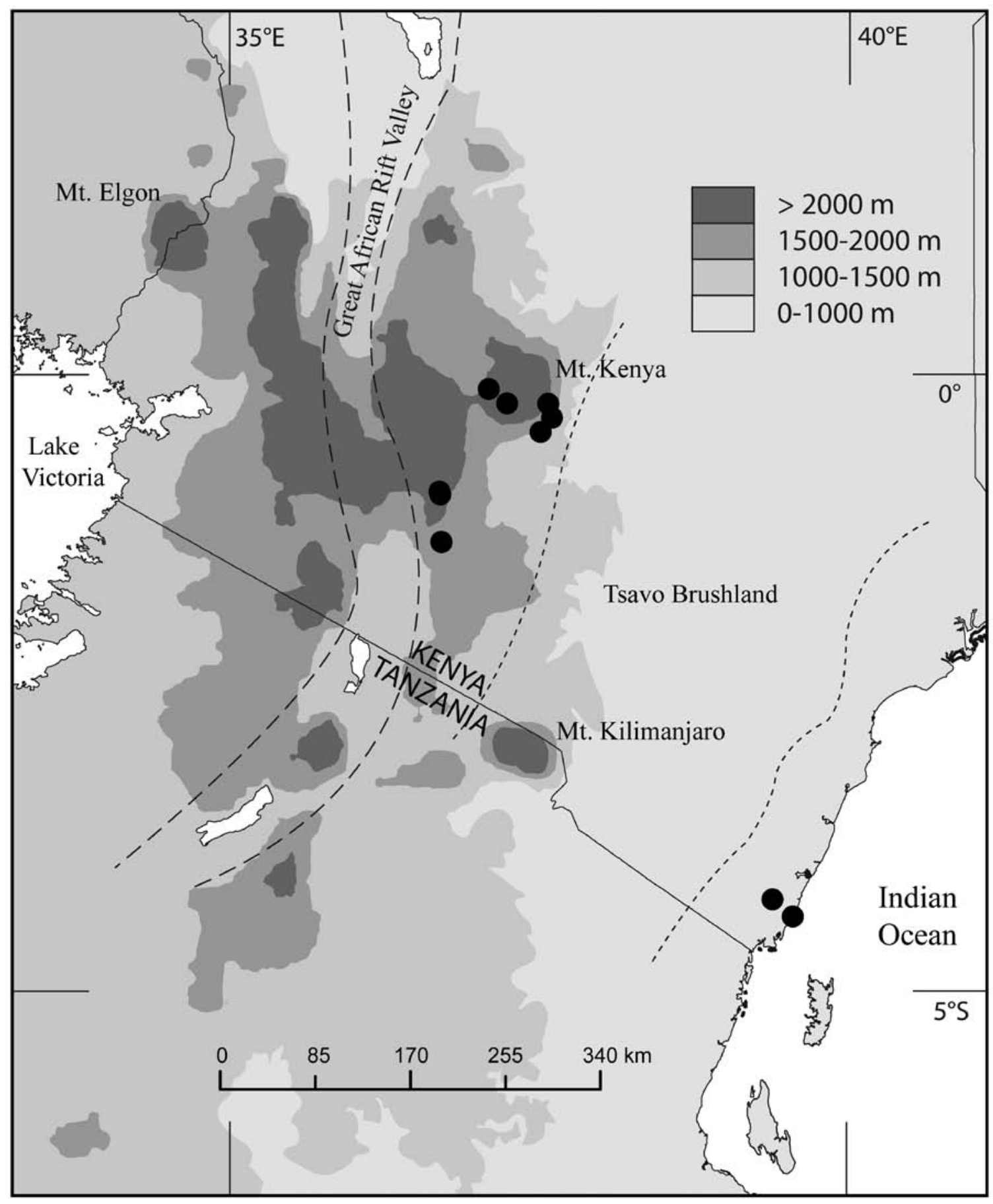

MAP 11. Distribution of Blastobasis chuka.

A \& M Coll[ection] \# 2020, r.f. Vepris simplicifolia"; " O Slide 4905"; "00196886"; " đ Genitalia Slide by DA, USNM 83449”; “ \ Slide 4906”; “00196887”; “ đ Genitalia Slide by DA, USNM 83433” [USNM]; 1 ๙ , 1 q, “Mt. Kenya Forest, 0¹4.256'S, 37³3.924'E, 2040 m, 7 Nov. 2001, A \& M Coll[ection] \# 1521, r.f. Chrysophyllum gorungosanum”; “స Slide 4914”; “00196888” [BMNH]; "00196413" [USNM]; 2 , data as above except, "6

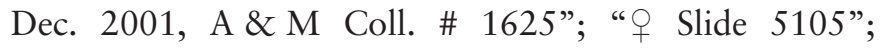
“00196366” [BMNH]; “00196414” [USNM]; 1 ๙, data as above except, "7 Nov. 2001, R.S. Copeland"; "ex. fruits, Chrysophyllum gorungosanum, Coll. \# 1521” “ O Slide 
5066”; “00196404”; “ $§$ Genitalia Slide by DA, USNM 83444" [USNM]; 1 + , data as above except, " $0^{\circ} 14.19$ 'S, 37³7.14'E, 1893 m, 9 April 2002, A \& M Coll. \# 1870, r.f. unknown fruit”; “ㅇ Slide 5120”; "00196380"; “우 Genitalia Slide by DA, USNM 83434” [USNM]; 1 +, “Mt. Kenya Forest, $0^{\circ} 14.19^{\prime}$ ', 37³4.14'E, 1893 m, 9 April 2002, A \& M Coll. 1870, r.f. unknown fruit"; “o Slide 4907”; “00196320”; “ㅇ Genitalia Slide by DA, USNM 83435" [USNM]; 3 ô, "Gatamayu Forest, $0^{\circ} 58.45^{\prime} \mathrm{S}$, 36²4.83'E, 17 April 2001, A \& M Coll. \# 1170, r.f. Podocarpus latifolius"; "O Slide 5042"; "00196889" [NMK];

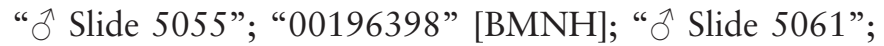
"00196403”; “ đ Genitalia Slide by DA, USNM 83436” [USNM]; 1 , data as above except, "A \& M Coll. 1169, r.f. Landolphia buchananii"; “ \ Slide 5058”; "00196400";

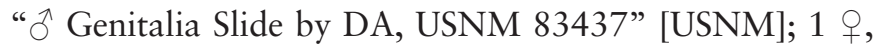
data as above except, "A \& M Coll. 1179, r.f. Allophylus abyssinicus"; "o Slide 5090"; "00196354" [NMK]; 2 +, data as above except, "2284 m, 17 April 2001, A \& M Coll. \# 1170, r.f. Podocarpus latifolius”; “o Slide 5108”; "00196369"; "o Genitalia Slide by DA, USNM 83438” [USNM]; "00196418” [USNM]; 2 , data as above except, "A \& M Coll. \# 1169, r.f. Landolphia buchananii"; "o Slide 5112”; “00196373” [MRAC]; "00196406" [USNM]; 1 +, data as above except, "A \& M Coll. \# 1177, r.f. Passiflora mollissima"; "O Slide 5100"; "00196364"; “q Genitalia Slide by DA, USNM 83439" [USNM]; 1 , data as above except, " $0^{\circ} 57.12^{\prime} \mathrm{S}, 36^{\circ} 41.43^{\prime} \mathrm{E}$, Coll. 23 March 1999, Lot 38, r.f. Garcinia volkensii"; "o Slide 5097”; “00196361”; “ㅇ Genitalia Slide by DA, USNM 83440" [USNM]; 1 ${ }^{\lambda}$, data as above except, "Ololua Forest, ca. $1^{\circ} 21.534^{\prime} \mathrm{S}, 36^{\circ} 42.417^{\prime} \mathrm{E}, 16$ Aug. 1999, Coll. A \& M 244, r.f. Drypetes gerrardii fruit"; “ $\bigcirc$ Slide 4226"; "00196890" [NMK]; 1 गे, data as above except, "Shimba Hills, $4^{\circ} 15.42^{\prime}$ S, 39²2.96E, 23 April 2002, A \& M Coll. \# 1896, R.S. Copeland, ICIPE/USAID, r.f. Dictyophleba lu-

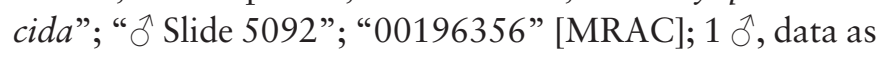
above except, "Kaya Kinondo, ca. $4^{\circ} 23.71$ S, 39³2.84'E, coll. 20 July 2000, R. Copeland, Coll. A \& M 767, r.f. Di-

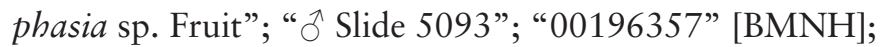
1 , data as above except, "Koru/Brooks, ca. $0^{\circ} 8.87$ 'S, $35^{\circ} 15.77$ 'E, 17 Aug. 2000, Lot 808, r.f. Flacourtia indica"; " 1 Slide 4344"; "00196301"; "O Genitalia Slide by DA, USNM 83445" [USNM]; 2 , data as above except, "Chuka Forest, 0²1.06'S, 37³5.80'E, 1600 m, 20 Jan. 2003, A \& M Coll. \# 2372, r.f. Prunus africana"; "q Slide 5031"; "00196881"; “ㅇ Genitalia Slide by DA, USNM 83441” [USNM]; “o Slide 5029”; “00196879”; “ $q$ Genitalia Slide by DA, USNM 83442” [USNM]; 1 , “Kirimiri Forest, $0^{\circ} 25.62^{\prime} \mathrm{S}, 37^{\circ} 32.83^{\prime} \mathrm{E}, 1710 \mathrm{~m}, 28$ Aug. 2002, A \& M Coll. \# 2197, R.S. Copeland, ICIPE/USAID, r.f. Rawsonia lucida"; “o Slide 4917”; “00196323”; “o Genitalia Slide by DA, USNM 83443" [USNM]. Paratypes deposited in BMNH, MRAC, NMK, and USNM.

ETYMOLOGY. The species epithet, chuka, is derived from Chuka Forest, the type locality.

Distribution. Blastobasis chuka is known from habitats along the southeastern coast and in the central highlands.

Hosts. Fruits of Allophylus abyssinicus (Hochst.) Radlk. (Sapindaceae); Chrysophyllum gorungosanum Engl. (Sapotaceae); Dictyophleba lucida (K. Schum.) Pierre (Apocynaceae); Diphasia sp. (Rutaceae); Drypetes gerrardii Hutch. (Euphorbiaceae); Flacourtia indica (Burm. F.) Merr. (Salicaceae); Garcinia volkensii Engl. (Clusiaceae); Landolphia buchananii (Hallier f.) Stapf. (Apocynaceae); Passiflora mollisima (Kunth) L. H. Bailey (Passifloraceae); Podocarpus latifolius (Thunb.) Mirb. (Podocarpaceae); Prunus africana (Hook.f.) Kalkman (Rosaceae); Rawsonia lucida Harv. \& Sond. (Achariaceae); Vepris simplicifolia (Engl.) Mziray (Rutaceae).

\section{Blastobasis elgonae Adamski, new species}

\author{
FIGURES 15, 49, MAP 12
}

Diagnosis. Blastobasis elgonae is most similar to $B$. indigesta but differs from the latter by having a narrower uncus, a narrower gnathos, more tergal setae on dorsolateral part of tegumen, a broader apicoventral margin of the lower part of the valva, and a longer aedeagus.

\section{Description.}

Head: Vertex and frontoclypeus with scales grayish brown tipped with white; labial palpus with outer margin of segments I and II grayish brown intermixed with pale brown scales to near apical margin, segment III brown intermixed with few pale gray scales; scape of antenna pale gray, flagellum gray; male first flagellomere dilated, forming a notch between itself and flagellomeres 2-4. Proboscis pale grayish brown.

Thorax: Tegula and mesonotum with scales grayish brown tipped with pale gray. Legs grayish brown with a pale gray band on apices of all segments and tarsomeres. Forewing (Figure 49) length $6.8 \mathrm{~mm}(n=1)$, grayish brown intermixed with grayish brown scales tipped with pale gray, pale gray scales, and a few dark brown scales; median fascia complete, margin demarcated with pale gray scales; cell with three small dark brown spots, one spot near middle and two spots on distal end near crossvein. Undersurface grayish brown. Hindwing pale gray.

Abdomen: Male genitalia (Figure 15): Uncus narrow, parallel sided from a slightly widened base, subapically 


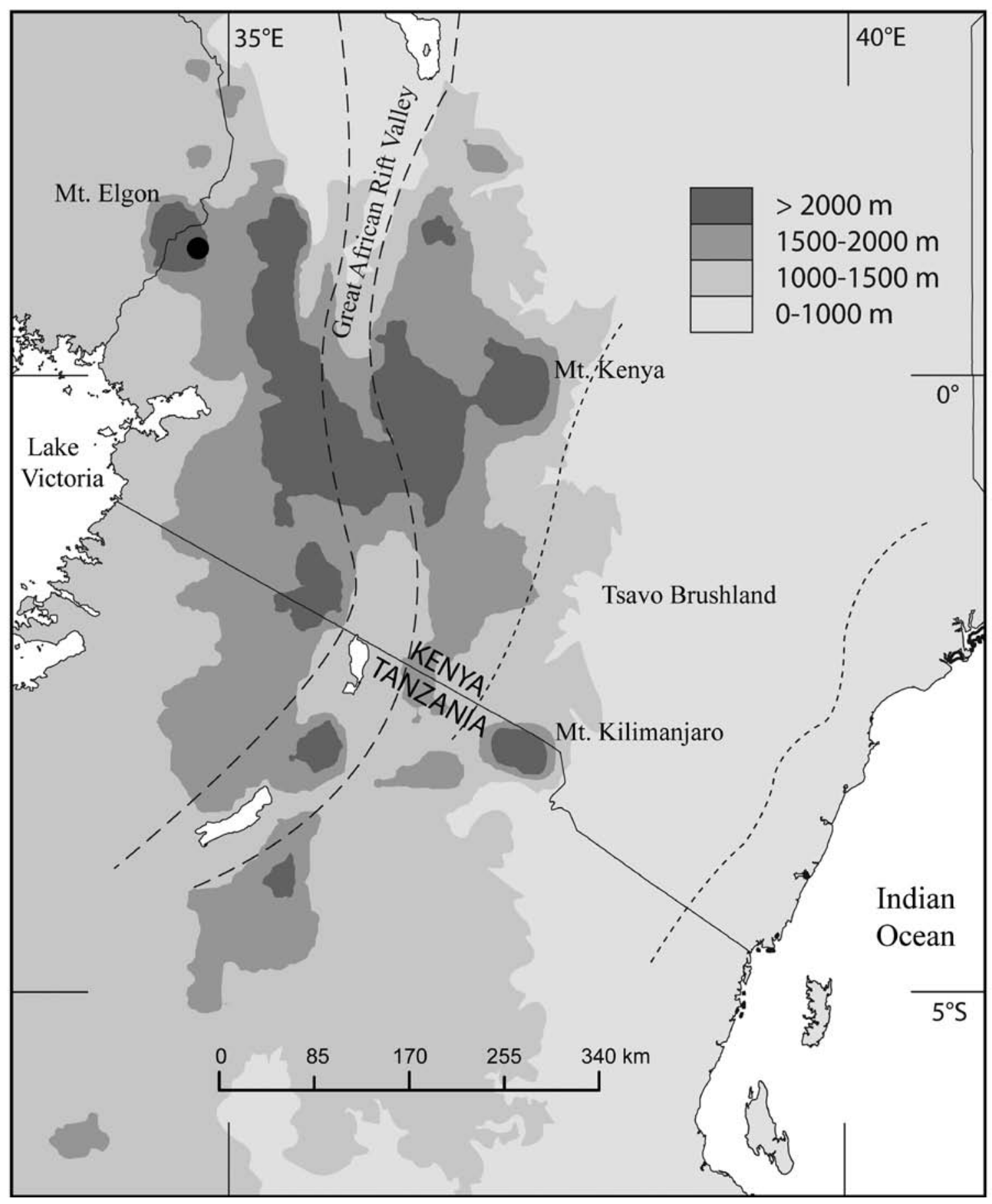

MAP 12. Distribution of Blastobasis elgonae.

curved, apex rounded narrowly; gnathos narrow, dorsoposterior margin shallowly bidentate medially; vinculum wide; juxta bandlike; valva divided; costa of upper part produced into a setose, digitate process; proximal flange elongate, gradually widened distally, apicoventral margin broadly rounded, overlaid by dense microtrichiate membrane, contiguous with digitate process; lower part of valva moderately wide basally, slightly widened distally, subventral area reflexed to apicoventral margin; apicoventral margin broadly angular, produced into an inwardly curved, acuminate process; process dilated, inner surface flattened; aedeagus and sclerite of aedeagus abruptly curved near 
apical $1 / 3$; anellus broadly rounded apically, bearing several conical setae. Female genitalia: Unknown.

Holotype. $\widehat{\jmath}$, “Kenya: Mount Elgon, 2450 m, $1^{\circ} 01.73^{\prime} \mathrm{N}, 34^{\circ} 45.28^{\prime} \mathrm{E}, 1$ Feb. 2003, A \& M Coll[ection] \# 2446, R.S. Copeland; ICIPE/USAID, r.f. Vepris nobilis"; "Restrictions Apply, NMK/ICIPE, Agreement \# 5" [pur-

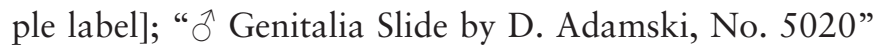
[yellow label]; “USNM ENT 00196891” [barcode label] [NMK].

Etymology. The species epithet, elgonae, is derived from Mount Elgon, the only known collecting site for Blastobasis elgonae.

Distribution. Blastobasis elgonae is known from one habitat on Mount Elgon in the western highlands.

Host. $\quad$ Fruits of Vepris nobilis (Delile) Mziray (Rutaceae).

\section{Blastobasis indigesta Meyrick, 1931, revised status}

FIGURES 8, 43

Blastobasis indigesta Meyrick, 1931:177.

Neoblastobasis indigesta: Sinev, 2004:116.

Diagnosis. Blastobasis indigesta is most similar to B. elgonae but differs from the latter by having a wider uncus, a wider gnathos, a linear apicoventral margin of the lower part of the valva, and a shorter aedeagus.

REDESCRIPTION.

Head: Vertex and frontoclypeus with scales brownish gray tipped white. Outer surface of labial palpus brownish gray intermixed with a few brownish gray scales tipped with white and a few white scales on segment II apically, inner surface paler. Scape of antenna with brownish gray scales tipped with white, flagellum pale gray; male first flagellomere dilated, forming a notch between itself and flagellomeres 2-4. Proboscis with scales brownish gray tipped with white.

Thorax: Tegula and mesonotum with scales brownish gray tipped with white. Leg scales brownish gray tipped with white, with a pale gray band on apices of all segments and tarsomeres. Forewing (Figure 43) length 7.0-7.9 mm $(n=3)$, brownish gray tipped with white intermixed with white scales. Three discal spots dark brown, one near midcell, two on distal end near crossvein. Fringe pale brown tipped with white. Undersurface brown. Hindwing pale brown.

Abdomen: Male genitalia (Figure 8): Uncus wide, slightly narrowed near midlength; gnathos wide, dorsoposterior margin narrowly bidentate medially; vinculum wide; juxta bandlike; valva divided; costa of upper part produced into a setose, digitate process; lower part of valva moderately wide, submarginal area reflexed to apicoventral margin; apicoventral margin slightly angular, produced into an inwardly curved, acuminate process; proximal flange subquadrate, apicoventral margin angular, overlaid by dense microtrichiate membrane, contiguous with digitate process; aedeagus and sclerite of aedeagus broadly curved; anellus bearing several conical setae. Female genitalia (poor dissection, not figured): Eighth tergum with a narrow, darkly pigmented median longitudinal streak; seventh sternum broad; ostium slightly posterior to seventh segment; ductus bursae thin, elongate, coiled and spinulate on anterior 1/16 length; corpus bursae slightly elongate, with hornlike signum on anterior end.

Lестотуре. Designated herein, $\widehat{\lambda}$, "Bulawayo, [Zimbabwe] 15-23 Dec. 1919, A.J.T. Janse"; "328”; "Blastobasis indigesta M[eyrick], Type No. 808"; "O Genitalia Slide by D. Adamski, No. 4735" [TMP]. A lectotype is being designated in order to maintain stability of usage of the name.

Paralectotypes (2 q). $q$, "Bulawayo, [Zimbabwe] 15-23, Dec. 1919, A.J.T. Janse"; “330"; "Blastobasis indigesta M[eyrick], Cotype No. 809"; "q Genitalia Slide by D. Adamski, No. 4736” [TMP]; ㅇ, "Syntype" [round, blue-bordered label]; "Bulawayo, Rhodesia, AJT J[anse], 12[Dec] 19[19]"; "Blastobasis indigesta Mey[rick], 1/1, E. Meyrick Det., in Meyrick Coll[ection]"; "Meyrick Coll[ection], B.M. 1938-290"; “indigesta Meyr[ick]”; "BM $q$ Genitalia Slide No. 19982” [BMNH]. The two female paralectotypes are in poor condition.

Remarks. Sinev (2004) erroneously transferred Blastobasis indigesta to Neoblastobasis and did not examine all available type specimens for this species.

\section{Blastobasis eridryas Meyrick, 1932}

FIGURES 18, 40

Blastobasis eridryas Meyrick, 1932:114.

Diagnosis. Blastobasis eridryas is most similar to B. elgonae and B. indigesta but differs from the latter two species by having a wider uncus, a wider digitate process of the upper part of the valve, a larger microtrichiate area of the valva, and a more conical anellus.

\section{REDESCRIPTION.}

Head: Vertex pale grayish yellow, some scales tipped with white. Outer surface of labial palpus with segments I and II brown, except apical margin of segment II pale grayish yellow; segment III pale grayish yellow intermixed 
with brown scales; inner surface pale grayish yellow intermixed with a few brown scales. Scape of antenna pale grayish yellow, flagellum gray; cilia long; male first flagellomere dilated, forming a notch between itself and flagellomeres $2-4$. Proboscis pale gray.

Thorax: Tegula and mesonotum grayish brown. Legs grayish brown, with a pale grayish yellow band near middle of all segments and apices of all segments and tarsomeres. Forewing (Figure 40) length $8.0 \mathrm{~mm}(n=1)$, pale brownish yellow intermixed with few brownish red scales tipped with pale grayish yellow on basal 2/3, distal $1 / 3$ with brownish red scales tipped with pale grayish yellow intermixed with brown scales tipped with pale grayish yellow and a few pale grayish yellow scales; a small rectangular gray spot near midcell. Undersurface brown. Hindwing pale gray.

Abdomen: $\quad$ Male genitalia (Figure 18): Uncus wide throughout length, slightly constricted near midlength, apex broadly rounded; gnathos wide, dorsoposterior margin broadly protuberant, shallowly bidentate medially; vinculum wide; juxta bandlike; valva divided; costa of upper part produced into a setose, digitate process; proximal flange elongate, apicoventral margin broadly rounded, overlaid by dense microtrichiate membrane, contiguous with digitate process; lower part of valva moderately wide, subventral area reflexed to apicoventral margin; apicoventral margin angular, produced into an inwardly curved, apical process; process broad basally, inner surface flattened; aedeagus and sclerite of aedeagus abruptly curved near apical 1/3; anellus gradually narrowed from base, bearing several conical setae. Female genitalia: Unknown.

Lестотуре. $\hat{O}$, Designated herein, "Type" [round, red-bordered label]; "[Ethiopia] Abyssinia, M[oun]t Chillálo, [Jem-Jem] Forest, ca 8500 f[ee]t, 24.IX.1926, H. Scott [Collector]"; "Brit[ish] Mus[eum], 1927-127"; "Blastobasis eridryas Meyr[ick], Type \$”; "Blastobasis eridryas n. sp”; “ $\widehat{O}$ BM Genitalia Slide No. 30245 " [BMNH]. A lectotype is being designated in order to maintain stability of usage of the name.

Remarks. A paralectotype $\delta$ with the same label data as lectotype, except “ $\bigcirc \mathrm{BM}$ Genitalia Slide No. 28894" [BMNH].

\section{Blastobasis mpala Adamski, new species}

$$
\text { FIGURES 17, 37, 55, MAP } 13
$$

Diagnosis. Blastobasis mpala is similar to $B$. egens in forewing pattern but differs genitally from the latter by having a smaller gnathos, a wider aedeagus, and female with a longer ductus bursae and corpus bursae with a signum present.

\section{Description.}

Head: Vertex and frontoclypeus pale yellowish brown; outer surface of labial palpus with segments I and II brown intermixed with pale yellowish brown scales to apical margin, segment III pale yellowish brown; inner surface pale yellowish brown; scape of antenna pale yellowish brown, flagellum pale brown; male first flagellomere dilated basally, forming a notchlike opening between the inner surface of the dilated part and flagellomeres 2-4. Proboscis pale yellowish brown.

Thorax: Tegula and mesonotum pale brown basally, pale yellowish brown apically. Legs pale brown with a pale yellowish brown band on apices of all segments and tarsomeres. Forewing (Figure 55) length 7.1-8.2 mm $(n=2)$, pale yellowish brown intermixed with pale brown scales and a few brown scales; cell with one small brown spot near middle and with one or two spots on distal end near crossvein. Undersurface brown. Hindwing pale brown.

Abdomen: Male genitalia (Figure 17): Uncus gradually narrowed from a wide base, slightly curved ventrally, apex slightly rounded; gnathos wide, dorsoposterior margin bidentate medially; vinculum wide, juxta bandlike; valva divided; costa of upper part produced into a setose, digitate process; proximal flange subquadrate, apicoventral margin slightly rounded, overlaid by dense microtrichiate membrane, contiguous with digitate process; lower part of valva moderately wide, subventral area reflexed to apicoventral margin; apicoventral margin angular, produced into an inwardly curved acuminate process; process flattened on inner surface; aedeagus straight, slightly widened basally; sclerite of aedeagus abruptly curved near apical $1 / 3$ and near base; anellus truncated apically, bearing several conical setae. Female genitalia (Figure 37): Eighth tergum rectangular with an elongate darkly pigmented streak along the median longitudinal axis; ostium within membrane near posterior margin of seventh sternum; posterior margin of seventh sternum straight with narrowly rounded posterolateral margins; inception of ductus seminalis on ductus bursae slightly anterior to ostium; ductus bursae slightly shorter than ovipositor, with anterior 1/4 spinulate; corpus bursae with a hornlike signum.

Holotype. $\hat{0}$, "Kenya: Laikipia Plateau, Mpala Research Centre, $0.293^{\circ} \mathrm{N}, 36.899^{\circ} \mathrm{E}, 23-25$ May 1998, 1650 m, S.E. Miller \& T.M. Kuklenski”; "USNM ENT 00193006" [barcode label]; "Restrictions Apply, NMK-ICIPE, Agreement \# 5” [purple label]; “ $\widehat{o}$ Genitalia Slide by D. Adamski, No. 4137” [yellow label]. Deposited in NMK. 


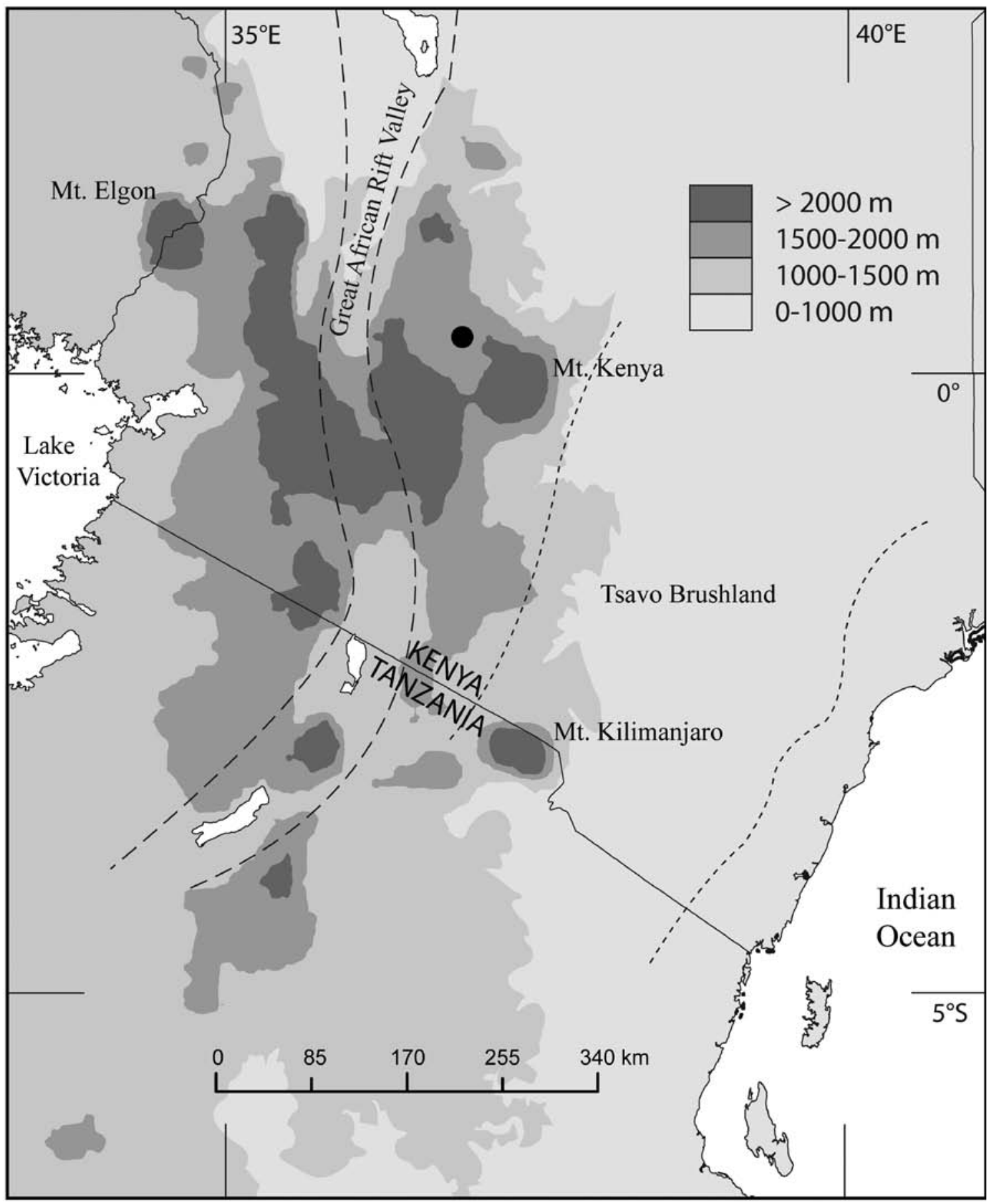

MAP 13. Distribution of Blastobasis mpala.

PAratype. + , Same label data as above, except "19-21 May 1999”; “S. E. Miller”; "USNM ENT

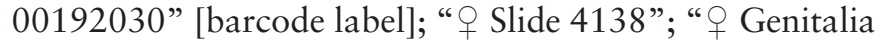
Slide by DA, USNM 83408” [USNM].
ETymology. Blastobasis mpala is named in honor of the Mpala Research Centre.

Distribution. Blastobasis mpala is known from savanna habitat in the central highlands. 


\section{Blastobasis egens Meyrick, 1918}

FIGURES 19, 24, 45

Blastobasis egens Meyrick, 1918:37.-Ghesquière, 1940: 68.-Sinev, 2004:116.

Diagnosis. Blastobasis egens is similar to B. mpala in forewing pattern, but it differs from the latter by having a more elongate gnathos, a smaller aedeagus, and female with a shorter ductus bursae and corpus bursae with a signum absent.

\section{REDESCRIPTION.}

Head: Vertex and frontoclypeus with scales pale brown tipped with white. Outer surface of labial palpus white intermixed with brown scales, with white along apical margin of segment II; inner surface white. Scape of antenna with scales pale brown tipped with white, flagellum gray, first flagellomere of male basally dilated, forming a notch between itself and flagellomeres 2-4. Proboscis pale brown.

Thorax: Tegula and mesonotum with scales brown tipped with white. Legs with scales brown tipped with white, with a white band on apices of all segments and tarsomeres. Forewing (Figure 45) length 4.5-4.9 $\mathrm{mm}(n=3)$, white intermixed with brown scales along costa and distal $1 / 2$; three brown spots in cell, one near middle, two on distal end near crossvein. Undersurface brown. Fringe brown tipped with white. Hindwing pale brown.

Abdomen: $\quad$ Male genitalia (Figure 19): Uncus gradually narrowed from a wide base, subapically curved ventrally, apex rounded narrowly; gnathos wide and elongate, dorsoposterior margin protuberant, bidentate medially; vinculum wide; juxta bandlike; valva divided; costa of upper part produced into a setose, digitate process; proximal flange elongate, apicoventral margin broadly rounded, overlaid by dense microtrichiate membrane, contiguous with digitate process; lower part of valve moderately wide, subventral area reflexed to apicoventral margin; apicoventral margin rounded, produced into an inwardly curved, acuminate process; aedeagus and sclerite of aedeagus slightly curved apically; anellus bearing several conical setae. Female genitalia (Figure 24): Eighth tergum with a narrow, darkly pigmented streak along median longitudinal axis; ostium slightly posterior to seventh segment; ductus bursae short, not extending beyond seventh segment; ductus seminalis slightly posterior to ostium; corpus bursae small, signum absent.

Lестотуре. Designated herein, $\hat{O}$, "Umkomaas, [South Africa] 25.1[January][19]14, A.J.T. Janse"; "25/30"; "Blastobasis egens M[eyrick], Cotype No. 800"; “ $\curvearrowright$ Genitalia Slide by D. Adamski, No. 4740" [TMP]. A lectotype is being designated in order to maintain stability of usage of the name.

Paralectotypes ( 3 ô, 3 क $). \quad$ + "Umkomaas, 1[January]14, A.J.T. Janse"; "26/58”; “B. egens M[eyrick]"; "Blastobasis egens M[eyrick], Type No. 796"; "O Slide 4743” [TMP]; Ô, "Nkwaleni, 10.1[January][19]16, A.J.T. Janse"; "25/37"; "Blastobasis egens

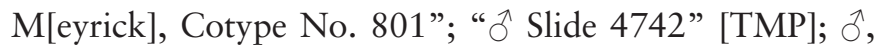
"Eshowe, Zululand, A.J.T. J[anse], 4.1[January][19]16, Blastobasis egens Meyr[ick], 7/3, E. Meyrick det., in Meyrick Coll[ection]"; "Meyrick Coll[ection], B.M. 1938290"; "BM ठ̊ Slide No. 30240" [BMNH]; + , "Nkwaleni, 10.1[January][19]16, A.J.T. Janse"; "25/56"; "Blastobasis egens M[eyrick], Cotype No. 799"; “o Slide 4744” [TMP]; + , "Natal, New Hanover, A.J.T. Janse, 1[January]13[1916?]"; "Blastobasis egens Meyr[ick], 7/6, E. Meyrick det., in Meyrick Coll[ection]"; "Meyrick Coll[ection], B.M. 1938-290"; "BM क Slide No. 30241" [BMNH]; ô, "New Hanover, Hardenb, 1[January]13[1916?], Coll[ector] Janse"; "25/04”; "Blastobasis egens M[eyrick], Cotype No. 811”; “ đ Slide 4741” [TMP].

ReMARKs. Blastobasis egens was described from a mixed series of 10 specimens, 3 of which are missing. Three female paralectotypes from New Hanover, Nkwaleni, and Umkomaas represent different species. The female from Umkomaas is believed to be conspecific with the male holotype, but the slide-mounted genitalia are in poor condition and are not illustrated. The paralectotype $\delta$ from Verulam is not conspecific with the holotype. In addition, a female specimen in the Transvaal Museum bearing the following label data is not believed to be part of the original type series and is not dissected: "Maritzburg, 1.2.[19]16, A.J.T. Janse"; “39/93”; "Blastobasis egens M[eyrick], Cotype No. 797”.

Sinev (2004) and Ghesquière (1940) made erroneous host associations between reared moth samples and several plant species, including Borassus aethiopum Mart. (Arecaceae), by not comparing dissected type material of Blastobasis egens with the reared specimens.

\section{Blastobasis fatigata Meyrick, 1914}

FIGURES 7, 61

Blastobasis fatigata Meyrick, 1914a:195.-Janse, 1917: 192, check list._Sinev, 2004:116.

Diagnosis. Blastobasis fatigata can be distinguished easily from other African Blastobasis by having a cluster of large setae on the base of the digitate process of the upper part of the valva. 


\section{REDESCRIPTION.}

Head: Vertex and frontoclypeus with scales grayish brown tipped with white. Outer surface of labial palpus with scales grayish brown tipped with white intermixed with few brown scales tipped with white, inner surface paler. Scape of antenna with scales grayish brown tipped with white, flagellum pale gray; first flagellomere unmodified in male. Proboscis pale grayish brown.

Thorax: Tegula and mesonotum dark brown basally, pale grayish brown apically. Legs pale brown intermixed with grayish brown scales tipped with white and dark brown scales tipped with white, and a pale brown band near middle of all segments apices of all segments and tarsomeres. Forewing (Figure 61) length $6.0 \mathrm{~mm}(n=1)$, scales pale grayish brown tipped with white intermixed with few brown scales and brown scales tipped with white; base of costa brown; cell with two faint brown spots, one near middle and one near distal end; one faint brown spot outside cell posterior to spot near distal end; marginal spots faint. Fringe pale brownish gray, darkening to apex. Undersurface brown. Hindwing pale brown, gradually darkening to apex.

Abdomen: Male genitalia (Figure 7): Uncus wide basally, subapically curved ventrally, gradually narrowed, apex narrowly rounded; gnathos elongate, dorsoposterior margin slightly protuberant, bidentate medially; dorsal strut present; vinculum narrow; juxta divided; valva divided; ventrodistal margin of proximal flange subquadrate, overlaid by dense microtrichiate membrane, contiguous distally with a setose, digitate process; middle area of upper part bearing a cluster of several large spinelike setae; lower part of valva moderately wide, subventral area reflexed to apicoventral margin; apicoventral margin rounded, produced into an inwardly curved, acuminate process; aedeagus and sclerite of aedeagus acutely curved near apical 1/3; anellus bearing several conical setae. Female genitalia: Unknown.

Holotype. ô, "Pretoria, [South Africa] 25.2. [Feb][19]13, A.J.T. Janse"; “36/40”; "B. Fatigata”; "D. Adamski Genitalia slide no. 4378"; "Blastobasis fatigata M[eyrick], Type No. 804” [TMP].

\section{Blastobasis taricheuta Meyrick, 1909}

\section{FIGURES 26, 50}

Blastobasis taricheuta Meyrick, 1909:372.-Janse, 1917: 192, check list._Sinev, 2004:116.

Diagnosis. Blastobasis taricheuta is similar in wing pattern to $B$. trachilista but can be distinguished from the latter genitalically by having a wider ostium, antrum, and posterior part of ductus bursae, and an inner surface of the corpus bursae that is not spinulate.

Relationships between Blastobasis taricheuta and $B$. trachilista are uncertain because the males of both species are unknown.

REDESCRIPTION.

Head: Vertex and frontoclypeus brown. Outer surface of labial palpus brown intermixed with pale brown scales on apical margin of segment II and basal area of segment III; inner surface brown intermixed with pale gray scales. Scape and flagellum of antenna brown. Proboscis brown.

Thorax: Tegula and mesonotum brown. Legs brown, with a pale brown band near middle of all segments and apices of all segments and tarsomeres. Forewing (Figure 50) length $9.6 \mathrm{~mm}(n=1)$, brown intermixed with a few pale brown scales. Fringe brown. Undersurface brown. Hindwing pale brown.

Abdomen: Male genitalia: Unknown. Female genitalia (Figure 26): Eighth sternum with a darkly pigmented streak along median longitudinal axis; ostium slightly posterior to seventh segment; membrane posterolateral to ostium microtrichiate; posterior margin of seventh sternum broadly emarginated medially; ductus seminalis slightly anterior of antrum; ductus bursae longer than ovipositor, with anterior $1 / 3$ with rows of internal, imbricate platelets; corpus bursae elliptical, with a hornlike signum on posterior end.

Holotype. $\quad$ +, "Type" [red label]; "[South Africa], Cape T[own], Lightfoot"; "Blastobasis taricheuta Meyr[ick], Type"; "Meyrick Det.”; “o Genitalia Slide by D. Adamski, No. 4539” [yellow label] [SAMC].

\section{Blastobasis trachilista Meyrick, 1921}

\author{
FIGURES 25, 52
}

Blastobasis trachilista Meyrick, 1921:117.-Sinev, 2004: 116.

Diagnosis. Blastobasis trachilista is similar in wing pattern to $B$. taricheuta, but it can be distinguished genitalically from the latter by having a narrower ostium, antrum and posterior part of ductus bursae, and an inner surface of the corpus bursae that is densely spinulate. Relationships between Blastobasis trachilista and B. taricheuta are uncertain because the males for both species are unknown.

\section{REDESCRIPTION.}

Head: Vertex and frontoclypeus pale yellow. Outer surface of labial palpus with segment I and basal $1 / 3$ of 
segment II brownish yellow, distal 2/3 of segment II and segment III pale brown; inner surface pale yellow. Scape of antenna pale reddish brown intermixed with pale yellowish brown, flagellum brown. Proboscis pale yellow.

Thorax: Tegula and mesonotum brown or brown with pale yellow scales basally. Legs brown, with a pale brown transverse band near middle of all segments and apices of all segments and tarsomeres. Forewing (Figure 52) length 6.0-6.2 $\mathrm{mm}(n=2)$, pale reddish brown intermixed with reddish brown scales tipped with pale brown and pale brown scales. Three brown spots present in cell, one near midcell and two near distal end near crossvein. Undersurface brown. Hindwing pale brownish gray.

Abdomen: Male genitalia: Unknown. Female genitalia (Figure 25): Eighth tergum with a narrow, darkly pigmented streak along median longitudinal axis; ostium within membrane slightly posterior to seventh sternum; membrane r lateral and posterolateral to ostium microtrichiate; seventh sternum straight; antrum short; inception of ductus seminalis proximal to ostium; ductus bursae shorter than ovipositor, with rows of internal, imbricate platelets on anterior $1 / 3$; corpus bursae densely spiculate; signum hornlike with a conical base.

Leстотуре. Designated herein, $q$, "Umtali, Rhodesia [Zimbabwe], A.J.T. J[anse], 13-1 [January][19]18"; "Blastobasis trachilista Meyr[ick], 1/1, E. Meyrick det., in Meyrick Coll[ection]”; "Meyrick Coll[ection], BM 1938-290"; "trachilista Meyr[ick]”; "BM $q$ Genitalia slide No. 30236" [BMNH]. A lectotype is being designated in order to maintain stability of usage of the name.

Paralectotype. $\quad$, "Umtali, Rhodesia, 4-1 [January]- [19]18, A.J.T. Janse”; “23/27”; “ $\propto$ Genitalia Slide by D. Adamski, No. 4490" [yellow label]; "Blastobasis trachilista M[eyrick], Type No. 807” [TMP]. Specimen has a badly damaged abdomen, which has been dissected and slide mounted.

\section{Blastobasis determinata Meyrick, 1921}

FIGURES 30, 41

\section{Blastobasis determinata Meyrick, 1921:116.-Sinev,} 2004:116.

Diagnosis. Blastobasis determinata is similar to B. byrsodepta in wing pattern, but it can be distinguished from the latter by having a narrower ostium and the absence of a cuplike antrum. Relationships of Blastobasis determinata and B. byrsodepta are uncertain because the males for both species are unknown.

\section{REDESCRIPTION.}

Head: Vertex and frontoclypeus with scales grayish brown, apically tipped with white. Outer surface of labial palpus grayish brown intermixed with a few grayish brown scales tipped with white, and white scales apically on segment I and basally on segment III; inner surface similar in pattern but paler. Scape of antenna with grayish brown scales tipped with white, flagellum gray. Proboscis with grayish brown scales tipped with white.

Thorax: Tegula and mesonotum with scales grayish brown tipped with white. Legs with scales grayish brown tipped with white, with a white band near middle of all segments and apices of all segments and tarsomeres. Forewing (Figure 41) length $5.9 \mathrm{~mm}(n=1)$, grayish brown intermixed with a few grayish brown scales tipped with white and white scales; basal 1/3 paler than distal 2/3; median fascia grayish brown, complete, demarcated on inner margin with a narrow band of white scales; two grayish brown spots near end of cell. Fringe grayish brown tipped with white. Undersurface grayish brown. Hindwing pale grayish brown.

Abdomen: Male genitalia: Unknown. Female genitalia (Figure 30): Eighth tergum without a pigmented streak along medial longitudinal axis; ostium within membrane slightly posterior to seventh sternum; membrane slightly microtrichiate on posteriolateral margins of ostium; posterior margin of seventh tergum slightly emarginated medially, with two or three transverse rows of spinelike setae on posterior end; inception of ductus seminalis on ductus bursae near posterior end of seventh segment; ductus bursae shorter than ovipositor, with several rows of internal, imbricate platelets on posterior $2 / 3$; corpus bursae slightly elongate, signum hornlike with a dilated base.

Holotype. क, "Moorddrift, [South Africa]

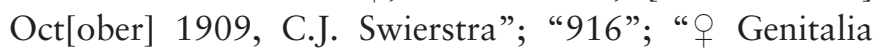
Slide by D. Adamski, No. 4488" [yellow label]; "Blastobasis determinata Meyr. Type No. 2552” [TMP].

\section{Blastobasis byrsodepta Meyrick, 1913}

$$
\text { FIGURES 34, } 47
$$

Blastobasis byrsodepta Meyrick, 1913:314.-Janse, 1917: 192, check list.—Hargraves, 1930:98.-Ghesquière, 1940:68, pl. II, figs. 11-12.—Sinev, 2004:116.

Diagnosis. Blastobasis byrsodepta is similar to $B$. determinata in wing pattern, but it can be distinguished genitalically from the latter by having a wider ostium and a cuplike antrum of the ductus bursae. 
Relationships of both species are uncertain because the males for both species are unknown.

\section{REDESCRIPTION.}

Head: Vertex and frontoclypeus with scales grayish brown tipped with white. Outer surface of labial palpus brown, inner surface paler. Scape of antenna with scales grayish brown tipped with white, flagellum gray. Proboscis with scales grayish brown tipped with white.

Thorax: Tegula and mesonotum with scales grayish brown tipped with white, basally dark, gradually paler to apex. Legs with grayish brown scales tipped with white, with a white band near middle of all segments and apices of all segments and tarsomeres. Forewing (Figure 47) length $6.0-7.0 \mathrm{~mm}(n=2)$, grayish brown scales tipped with white intermixed with pale grayish brown scales tipped with white and brown scales; median fascia complete, incomplete, or faint. Fringe grayish brown tipped with white. Undersurface brown. Hindwing pale grayish brown, gradually darkening to apex.

Abdomen: Male genitalia: Unknown. Female genitalia (Figure 34): Eighth sternum subquadrate; eighth tergum with a narrow and short, darkly pigmented area along median longitudinal axis; ostium slightly posterior to seventh segment; posterior margin of seventh sternum nearly straight; seventh tergum with several irregular rows of spinelike setae; inception of ductus seminalis near posterior margin of seventh segment; ductus bursae shorter than ovipositor, with rows of internal, imbricate platelets on anterior half; corpus bursae elliptical, with hornlike signum on posterior end.

Leстотуре. Designated herein, + , "Barberton, [South Africa] 31 Dec. 1910, A.J.T. Janse"; “31/07”; "Blastobasis byrsodepta"; "o Genitalia Slide by D. Adamski No. 4630"; "Blastobasis byrsodepta"; "M[eyrick], Type No. 795" [TMP]. A lectotype is being designated in order to maintain stability of usage of the name.

Paralectotypes (2 $q$ ). 1 q, "Waterval Onder, 2 Nov. 1910"; "30/72"; “ + Genitalia Slide by D. Adamski, No. 4631"; "Blastobasis byrsodepta M[eyrick], Cotype No. 810" [TMP]; 1 क, "Pinetown, Natal, L[eigh], [?]1[Jan][19]09"; "Blastobasis byrsodepta Meyrick 8/3, E. Meyrick det., in Meyrick Coll[ection]"; "Meyrick Coll[ection], B.M. 1938-290"; "BM $q$ Genitalia Slide No. 30239" [BMNH].

REMARKs. Meyrick described Blastobasis byrsodepta from five specimens, four from Barberton and Waterval and one from Pinetown (Natal). Although the number of specimens from each of the Barberton and Waterval localities is not known, two specimens from this series are apparently missing. The female paralectotype from Pinetown is not conspecific with B. byrsodepta and represents another species of Blastobasini. A male from Eala (Democratic Republic of Congo), with Meyrick's syntypic labels [BM ð Genitalia Slide No. 30238], is not part of the original series from which B. byrsodepta was described and represents Neoblastobasis perisella n. sp.

Larvae of Blastobasis byrsodepta are reported to feed on stored ginger, Arachis hypogaea L. (Fabaceae) (Hargreaves, 1930), but this information was based on a misidentification of the moth species. Sinev (2004) and Ghesquière (1940) have erroneously made host associations between reared moth samples and two plant species, Borassus aethiopum Mart. (Arecaceae) and Zingiber offcinale Roscoe (Zingiberaceae), by not comparing dissected type material of Blastobasis byrsodepta with the reared specimens.

\section{Blastobasis industria Meyrick, 1913}

\section{FIGURES 32, 39}

Blastobasis industria Meyrick, 1913:314.-Janse, 1917: 192, check list.-Le Pelley, 1930:396.--Nonveiller, 1984:77.—Zhang, 1994:103.—Sinev, 2004:116.

Diagnosis. Blastobasis industria is similar in wing pattern to many other African Blastobasis, but it can be distinguished from its congeners by having a very wide ostium and large, cuplike antrum of the ductus bursae. The relationship of Blastobasis industria with other Blastobasis is uncertain because the male is not known and female characters tend to be conservative in nature.

\section{REDESCRIPTION.}

Head: Vertex pale brown or scales pale grayish brown tipped with white. Outer surface of labial palpus brown with pale brown scales along apical margin of segment II; inner surface pale brown with a few brown scales. Scape of antenna pale brown, flagellum pale gray; first flagellomere of antenna in male dilated basally, forming a notch between itself and flagellomeres 2-4. Proboscis pale brown.

Thorax: Tegula and mesonotum pale brown or with scales grayish brown tipped with white. Legs brown intermixed with brown scales tipped with white with a white band near middle of all segments and apices of all segments and tarsomeres. Forewing (Figure 39) length 7.9$9.9 \mathrm{~mm}(n=2)$, pale brown intermixed with brown scales tipped with white and brown scales (darker scales on distal 1/3); median fascia pale brown, incomplete; two brown spots within cell near crossvein, present or absent. Fringe pale brown. Undersurface brown. Hindwing pale brown. 
Abdomen: Male genitalia: Unknown. Female genitalia (Figure 32): Eighth tergum with an elongate, darkly pigmented streak along median longitudinal axis; ostium wide, slightly posterior seventh segment; antrum cuplike; membrane posterolateral to ostium slightly microtrichiate; posterior margin of seventh sternum straight; ductus bursae shorter than ovipositor, with imbricate platelets on anterior $1 / 3$; corpus bursae slightly elongate, with hornlike signum on anterior end.

Lестотуре. Designated herein, $\uparrow$, "Barberton, [South Africa] 28 Jan[uary] 1911, A.J.T. Janse"; “47/82”; "Blastobasis industria M[eyrick], Type No. 802"; “ㅇ Genitalia Slide by D. Adamski, No. 4737” [TMP]. A lectotype is being designated in order to maintain stability of usage of the name.

Paralectotype. $\quad$, "Barberton, 1 Jan[uary] 1911, A.J. T. Janse”; “47/73”; "B. Industria, 4782”; "Blastobasis industria M[eyrick], Cotype No. 803"; “ㅇ Genitalia Slide by D. Adamski, No. 4738” [TMP].

REMARKs. Blastobasis industria was described from four specimens, two of which are missing. Larvae of B. industria are reported to feed on the beans of coffee, Coffea arabica L. (Rubiaceae) (LePelley, 1930; Rungs, 1979; Zhang, 1994), but the specimens likely were misidentified because the genitalia of the type specimens had not been examined.

\section{DISCUSSION}

\section{Host Plant Distribution of Reared Blastobasinae}

The species of 11 blastobasines that were reared from fruits exhibited a wide range of hosts (Table 1). Among plant families, Sapotaceae was utilized most often, with Blastobasinae reared from $10(50 \%)$ of the 20 species sampled. Other important host families were Rutaceae (5 hosts, $31 \%$ of the species sampled), Salicaceae (3 hosts, $23 \%$ ), and Sapindaceae (4 hosts, 19\%). Interestingly, fruits of Rubiaceae were of negligible importance, i.e., only one species, Oxyanthus goetzei ssp. keniensis, of the 106 species of Rubiaceae sampled produced blastobasines. In contrast, nonblastobasine microlepidoptera were reared from 38 (36\%) Rubiaceae species, and Tephritidae (true fruit flies) were reared from 41 (39\%).

Four $(36 \%)$ of the 11 reared blastobasine species, Blastobasis catappaella, B. elgonae, B. millicentae, and Neoblastobasis wangithiae, came from a single host plant species, each of these representing a different plant family. Considering that we made 3847 collections of fruits from 927 plant taxa (most of these at the rank of species, with a few being subspecies or varieties) representing 117 families, these data provide strong evidence that monophagy is not uncommon in African blastobasines. Of the four monophagous species, only Neoblastobasis wangithiae did not share its host fruit (Pleiocarpa pycnantha) with other blastobasines. Of the two genera of Blastobasinae we reared from fruit, Neoblastobasis had a particularly limited host range, with N. wangithiae monophagous and both $N$. perisella and $N$. ximeniaella with only two hosts each, one of which was shared between them (Table 1).

The remaining five species, Blastobasis acirfa, B. aynekiella, B. chuka, B. glauconotata, and B. kenya were, to a greater or lesser extent, polyphagous, with B. kenya having the most hosts. This species was reared from fruits of 32 plant species, representing 22 families. Among frugivorous insects in Kenya, only the medfly, Ceratitis capitata (Wiedemann) (Tephritidae), and the false codling moth, Thaumatotibia leucotreta (Meyrick) (Tortricidae), exploited more fruit hosts than B. kenya. Through the course of the fruit survey we reared the medfly from 65 plant species representing 27 plant families, and we reared T. leucotreta from 85 species in 32 families (Copeland et al., 2009).

Among the polyphages, although there was considerable overlap among fruit hosts (Table 1), each Blastobasis species was reared from at least two fruit species that yielded no other Blastobasinae. Host exclusivity was most pronounced in Blastobasis glauconotata. It was the only blastobasine reared from 11 of its 17 (69\%) host fruit species. During fruit sampling, an effort was made to avoid the collection of obviously rotting fruit. However, because the condition of fruit samples and the location of fruits collected (on the ground or on the tree) were not consistently documented, no definitive statement can be made about whether the blastobasine moths reared in this study were feeding on live plant tissue or slightly decaying plant tissue.

\section{Geographical Distribution of Reared Blastobasinae}

In Kenya, there are two major barriers to east-west migration of plants and animals. The xeric floor of the Gregory Rift Valley separates western Kenya from the central highlands. The valley was formed by intermittent volcanic and rifting activity that began 15-12 MYA and has continued to near present. In the eastern part of the 


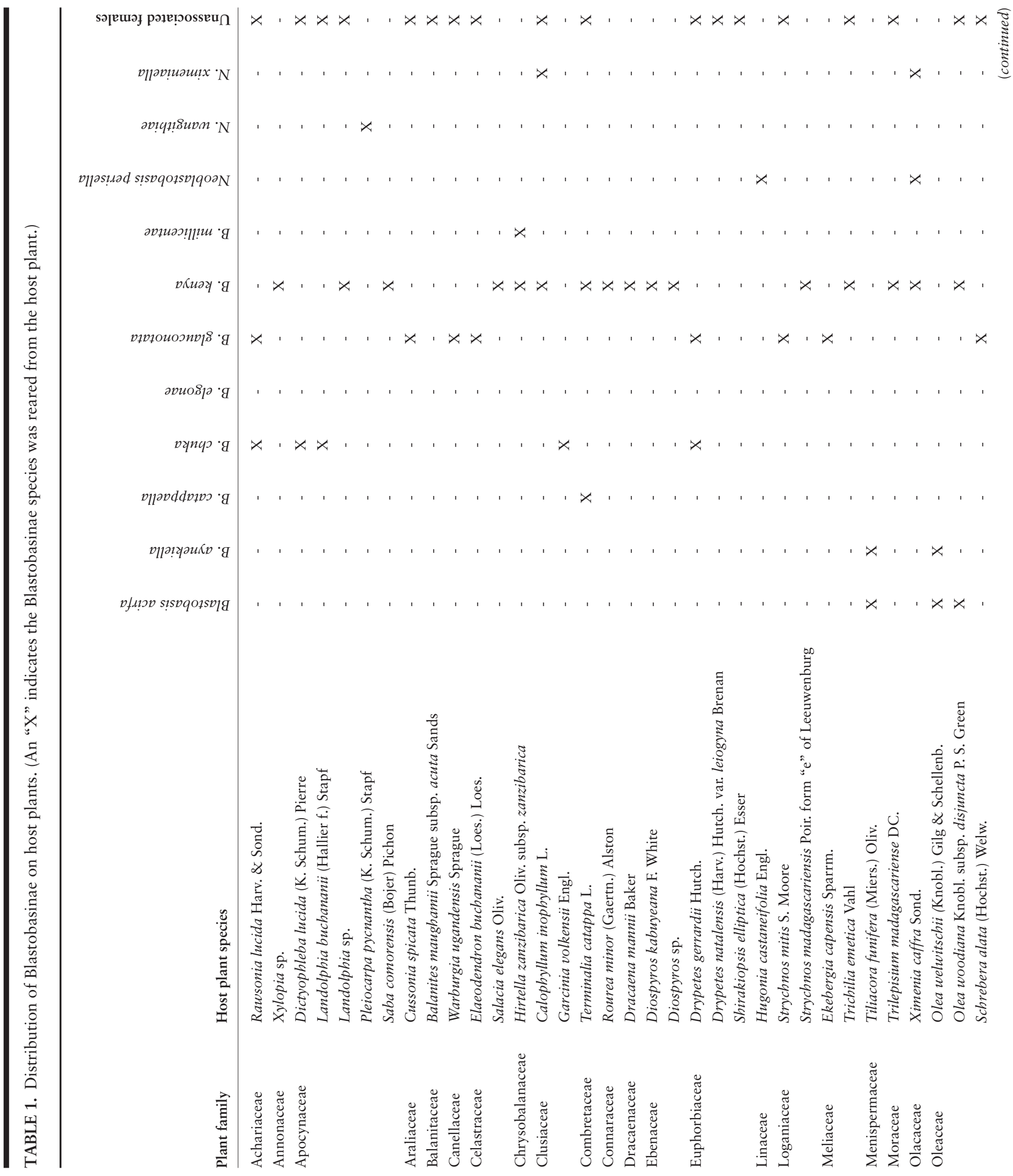




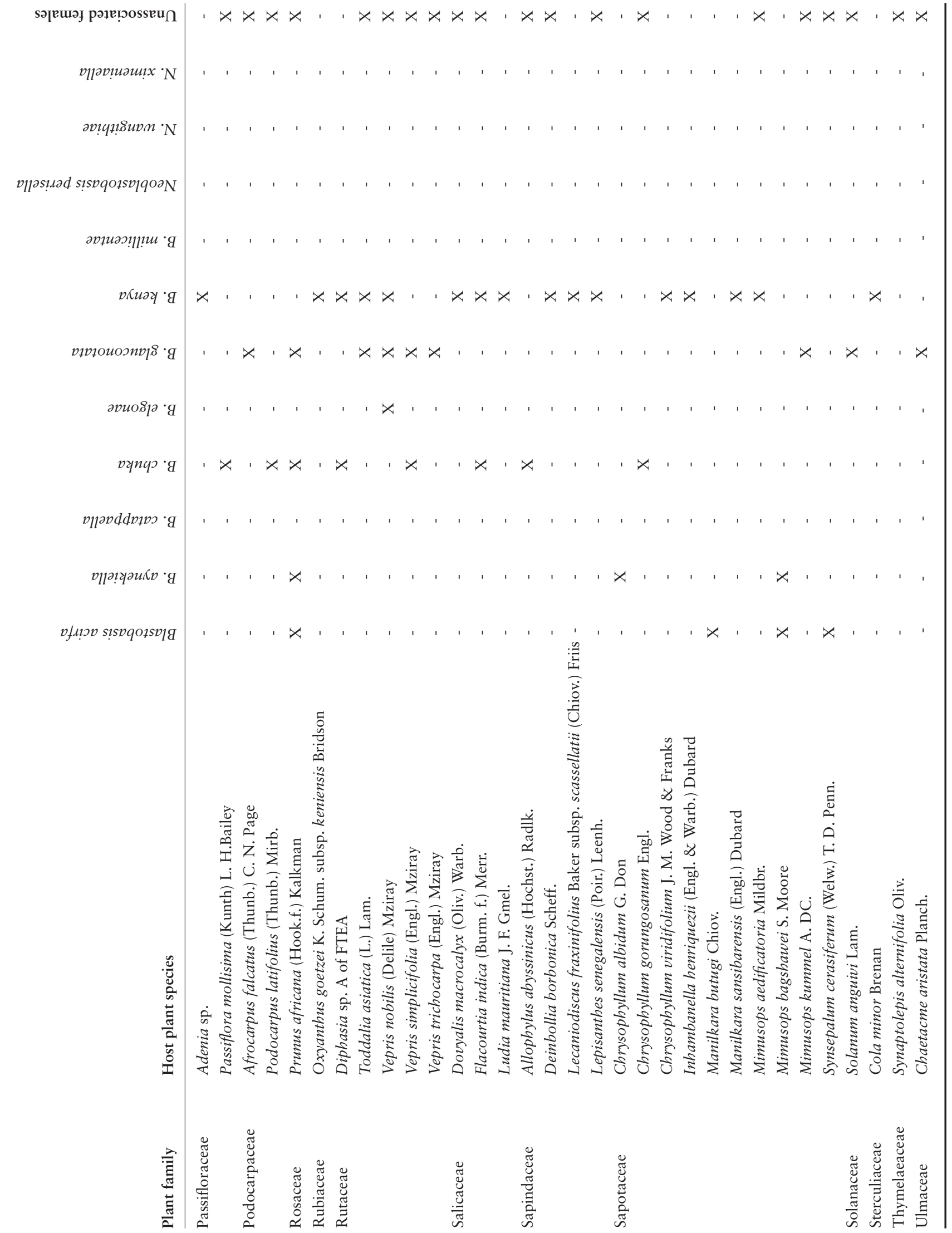


TABLE 2. Geographical distribution of Blastobasinae in Kenya.

\begin{tabular}{|c|c|c|c|}
\hline $\begin{array}{l}\text { Genus } \\
\text { and species }\end{array}$ & $\begin{array}{l}\text { Number of } \\
\text { fruit samples } \\
\text { reared from }\end{array}$ & $\begin{array}{c}\text { Regional distribution }{ }^{\text {a }} \\
\text { (number of } \\
\text { fruit samples) }\end{array}$ & $\begin{array}{l}\text { Altitudinal } \\
\text { distribution } \\
\text { (m) }\end{array}$ \\
\hline \multicolumn{4}{|l|}{ Blastobasis } \\
\hline acirfa & 11 & CO (1), WH (10) & $5-1650$ \\
\hline aynekiella & 8 & WH $(8)$ & $1550-1630$ \\
\hline catappaella & 1 & $\mathrm{CH}^{\mathrm{b}}, \mathrm{CO}(1)$ & $5-1650$ \\
\hline chuka & 15 & $\mathrm{CH}(12), \mathrm{CO}(2), \mathrm{WH}(1)$ & $5-2284$ \\
\hline elgonae & 1 & WH $(1)$ & 2450 \\
\hline glauconotata & 25 & $\mathrm{CM}(1), \mathrm{CH}(22), \mathrm{WH}(2)$ & $1230-2452$ \\
\hline kenya & 37 & $\mathrm{CO}(33), \operatorname{EM}(1)^{c}, \mathrm{WH}(3)$ & $5-2452$ \\
\hline millicentae & 1 & $\mathrm{CO}(1)$ & 389 \\
\hline mpala & 0 & $\mathrm{CH}^{\mathrm{b}}$ & 1650 \\
\hline \multicolumn{4}{|l|}{ Neoblastobasis } \\
\hline perisella & 2 & $\mathrm{CO}(2)$ & $101-389$ \\
\hline laikipiae & 0 & $\mathrm{CH}^{\mathrm{b}}$ & 1650 \\
\hline wangithiae & 1 & $\mathrm{CO}(1)$ & 30 \\
\hline ximeniaella & 2 & $\mathrm{CO}(2)$ & $5-101$ \\
\hline
\end{tabular}

country, a gently rising wide expanse of "dry scrub with trees" (Greenway, 1973) separates coastal habitats from the central highlands. Both barriers have very few plants with fleshy fruits, and these are represented primarily by species of Capparaceae, Cucurbitaceae, and Tiliaceae. In our survey, none of these plant families provided a single host plant for Blastobasinae. In contrast, the western and central highlands of Kenya support numerous areas of evergreen forests, as does the coast, providing an extensive resource for frugivorous insects. These forests have been connected and separated alternately, depending on climactic changes associated with glacial and interglacial periods, with the most recent period of connection occurring 10 MYA (Lovett, 1993; Burgess et al., 1998). Since then, there has been a trend toward increasing dryness in East Africa, although coastal and western forests may have been united 2.4 MYA (Burgess et al., 1998). Periodic forest connections and separations provide the conditions for allopatric speciation events, and the present richness of East African coastal forest endemics is thought to be due largely to them (Clarke, 2000). In all probability, they also affected the evolution and distribution of East African Blastobasinae.
In our survey, blastobasines were distributed throughout the sampling area (Table 2). Four species (Blastobasis millicentae, Neoblastobasis perisella, N. wangithiae, and N. ximeniaella) were restricted to coastal lowland habitats, and two (B. aynekiella and B. elgonae) were reared only from western Kenya, the former from several fruit species collected in Kakamega Forest, a Guineo-Congolean wet forest relict, and the latter from a single collection on Mount Elgon. Hosts of Blastobasis chuka and B. glauconotata were concentrated in the central highlands above $1600 \mathrm{~m}$, though each was reared from collections made in western Kenya, and B. chuka was also reared from coastal fruits. Blastobasis catappaella was reared from fruits collected on the coast and was collected with black light in a xeric central highland $(1650 \mathrm{~m})$. Blastobasis acirfa and $B$. kenya had disjunct distributions. Both were reared from coastal and western sites but not from the intervening central highlands (B. kenya also was collected once in midaltitude eastern Kenya). This pattern is also often seen in the distribution of many plant species (and genera) with coastal populations represented in relict forests that were connected during wetter periods to central African equatorial forest (Clarke, 2000). Blastobasis elgonae and 
B. aynekiella were the only species restricted to western Kenya. It will be interesting to determine if this species also occurs in central African equatorial forest. Blastobasis kenya had the widest altitudinal distribution, between 5 and $2452 \mathrm{~m}$ above sea level.

\section{DNA SEquence DatA}

Sequence data show three "outliers" in the compressed tree phenogram (Figure 1). An outlier sequence for one specimen of Blastobasis chuka (ô: 00196357, DA5093) occurs in sequence data for B. kenya, and two specimens of Blastobasis glauconotata (Õ: 00196387, DA5019 and ${ }^{\top}: 00196367$, DA 5106) almost match
B. elgonae. All outlier samples were sequenced twice to verify the data. We suspect contamination. Species identification of the specimens representing the abovementioned "outlier samples" is based solely on the features of the genitalia, although mislabeling of genitalia slides is a possibility.

In addition, the phenogram shows that Blastobasis millicentae (ô: 00196942, DA4910) is linked with a node uniting four species of Neoblastobasis, suggesting that Blastobasis and Neoblastobasis may be congeneric. Interestingly, males of species in both genera possess palmate sex scales on the inner surface of the antennal dilation of the first flagellomere. Only through a broader phylogenetic analysis will this problem be resolved. 


\section{FIGURES 2-62}

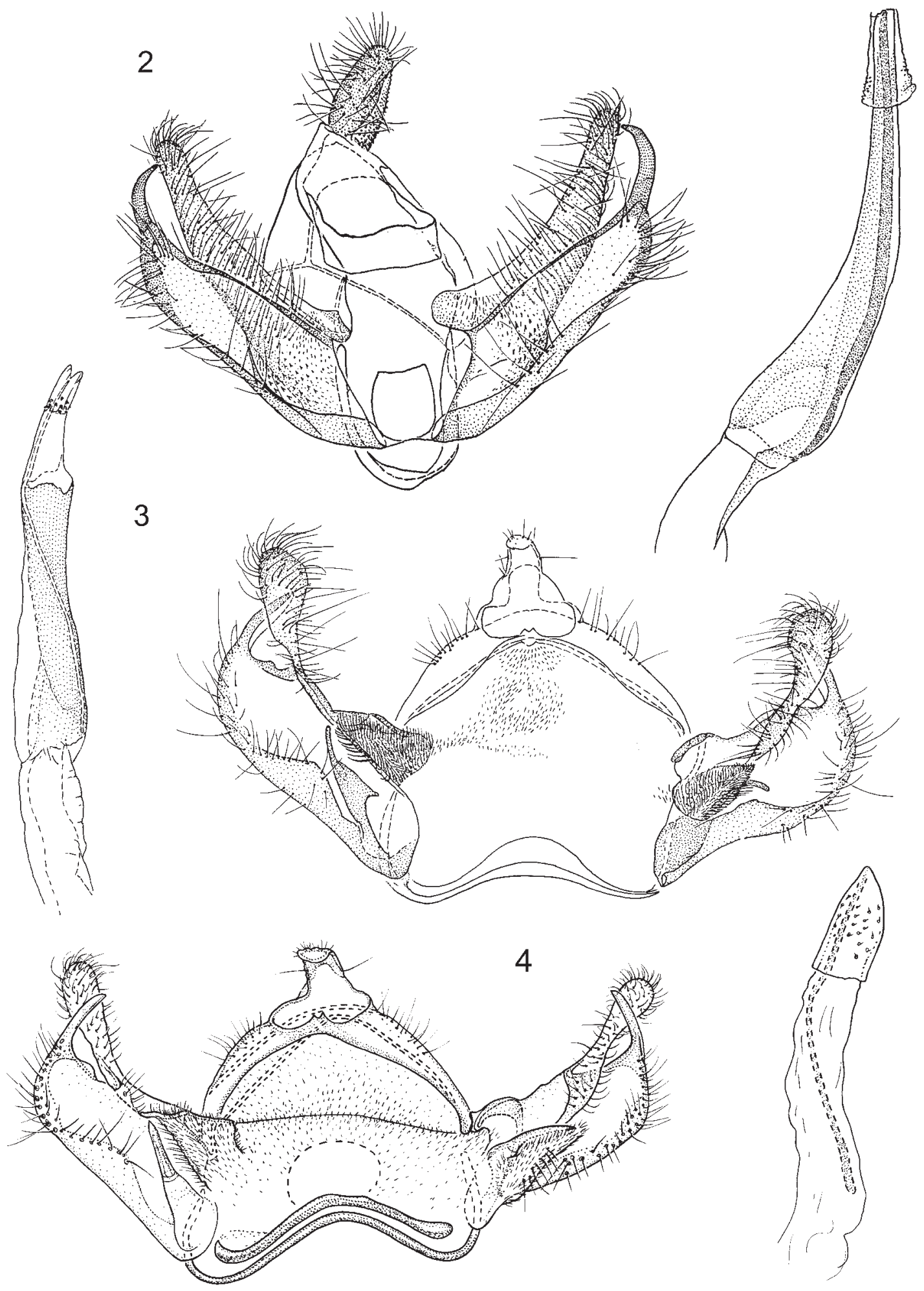

FIGURES 2-4. Male genitalia of Calosima and Neoblastobasis. 2, C. arguta, lectotype (DA slide 4628). 3, N. laikipiae, holotype (DA slide 4144). 4, N. wangithiae, holotype (DA slide 5044). 


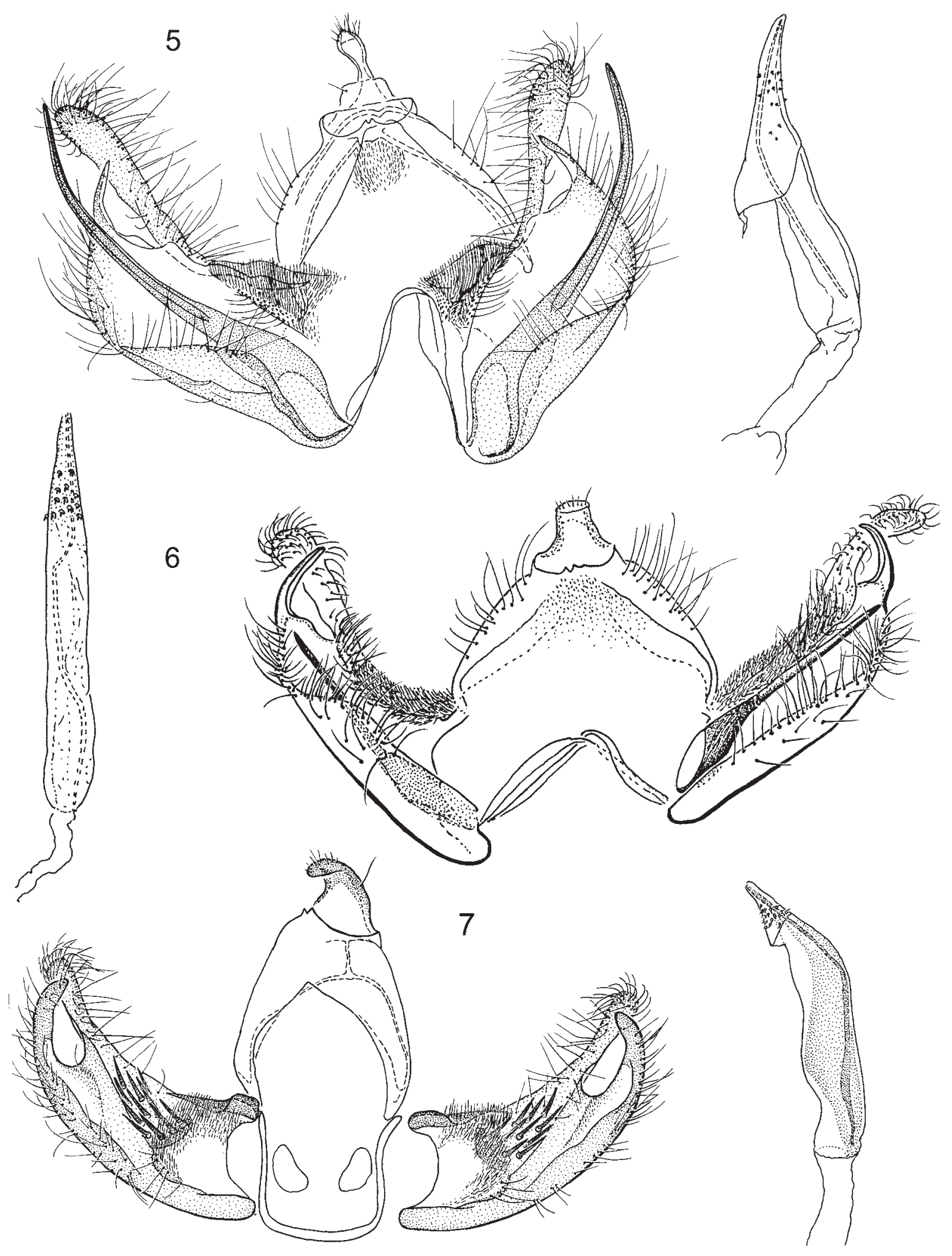

FIGURES 5-7. Male genitalia of Neoblastobasis and Blastobasis. 5, N. perisella, holotype (BM slide 30238). 6, N. ximeniaella, holotype (DA slide 5052). 7, B. fatigata, holotype (DA slide 4378). 

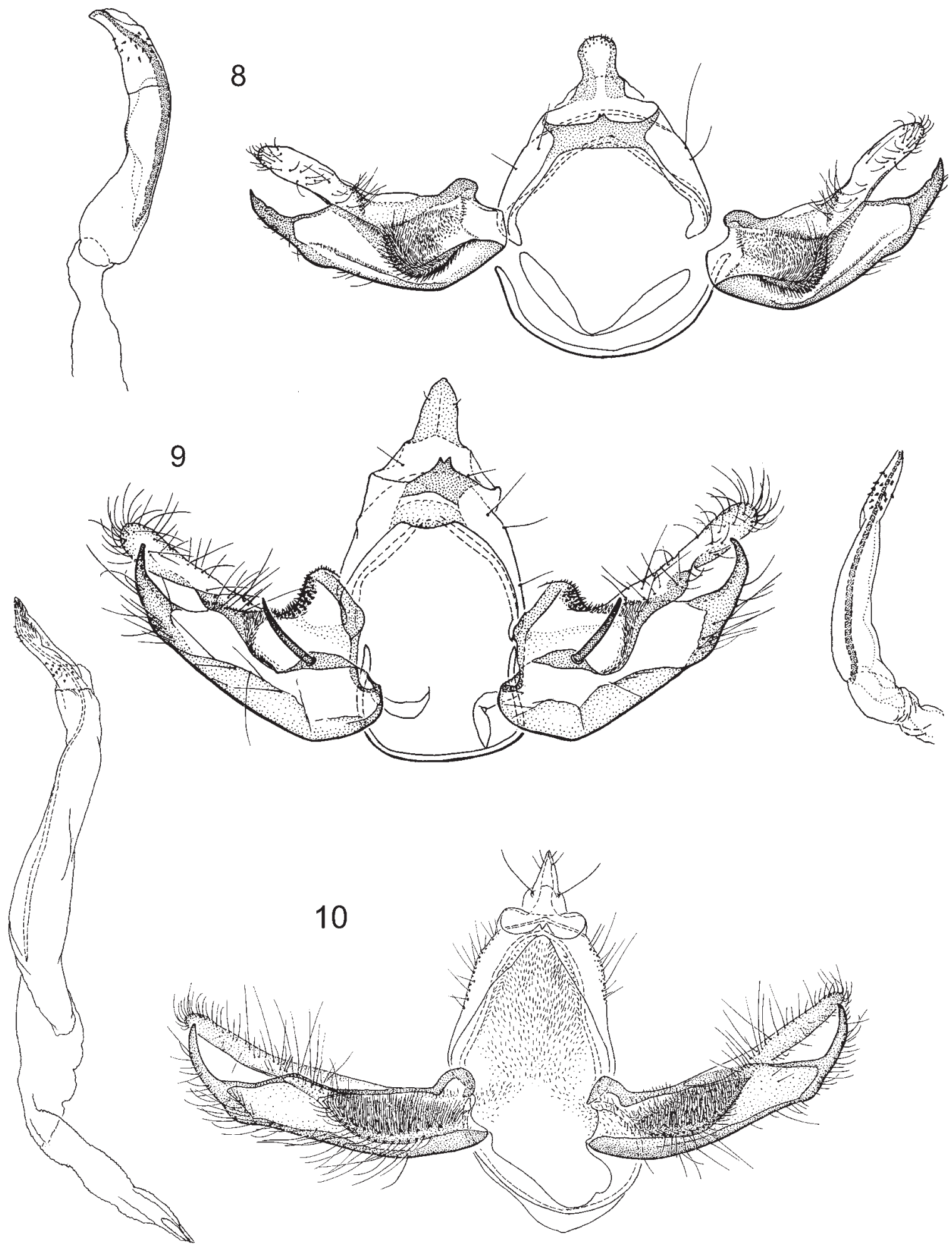

FIGURES 8-10. Male genitalia of Blastobasis. 8, B. indigesta, lectotype (DA slide 4735). 9, B. millicentae, holotype (DA slide 4739). 10, B. kenya, holotype (DA slide 4218). 


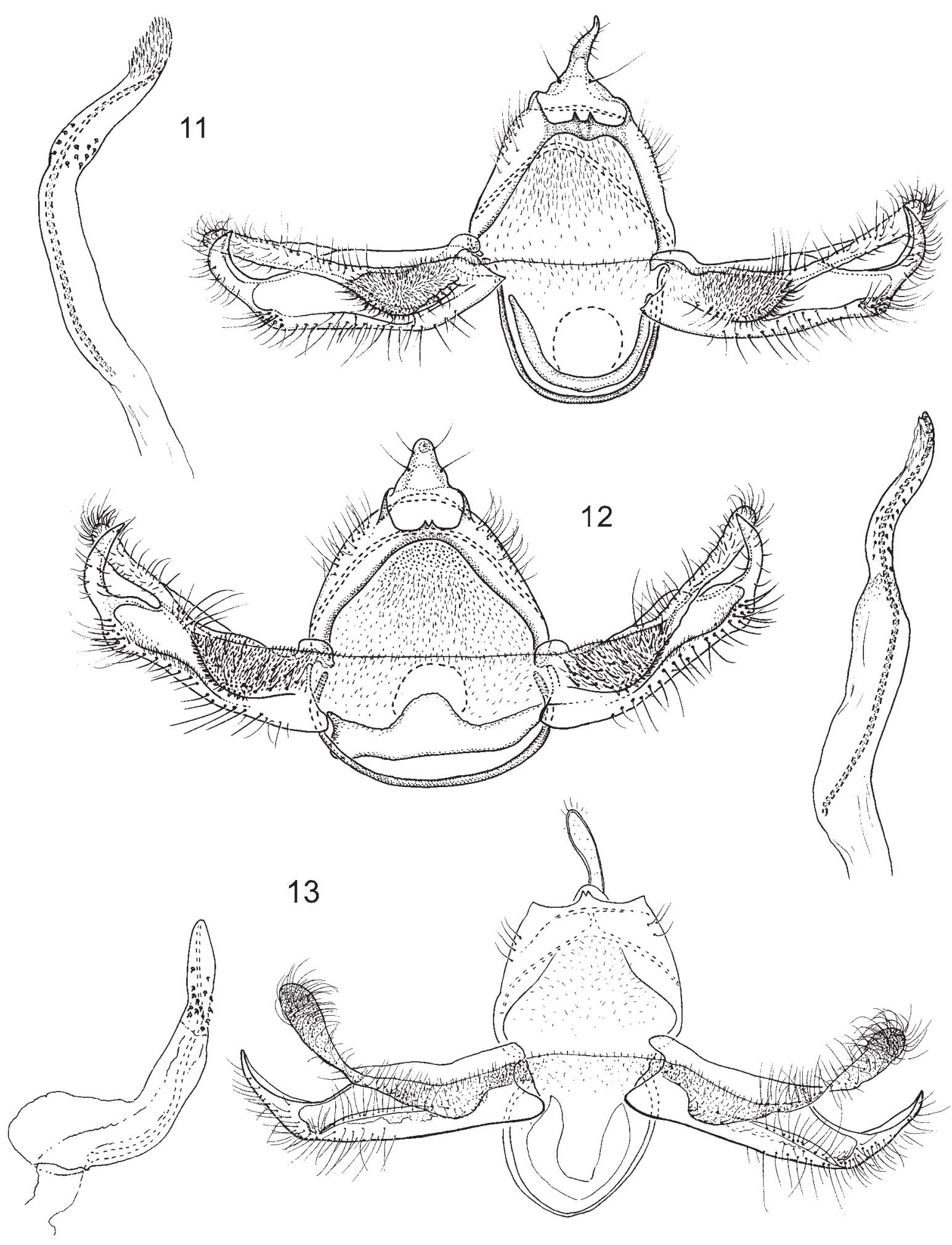

FIGURES 11-13. Male genitalia of Blastobasis. 11, B. acirfa, holotype (DA slide 5048). 12, B. aynekiella, holotype (DA slide 5045). 13, B. catappaella, holotype (DA slide 5071). 

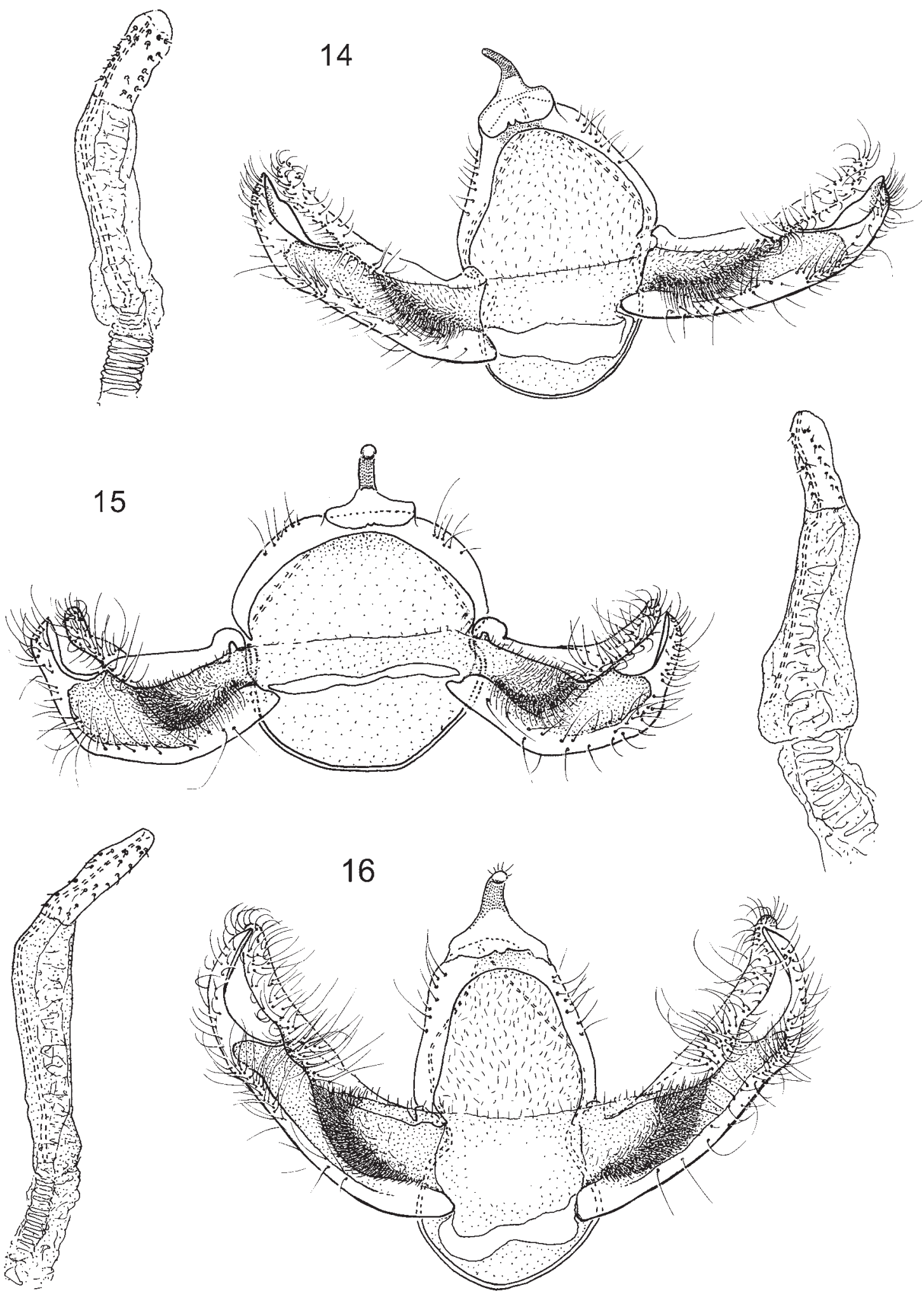

FIGURES 14-16. Male genitalia of Blastobasis. 14, B. glauconotata, paratype (USNM 83420, DA slide 5017). 15, B. elgonae, holotype (DA slide 5020). 16, B. chuka, holotype (DA slide 5025). 

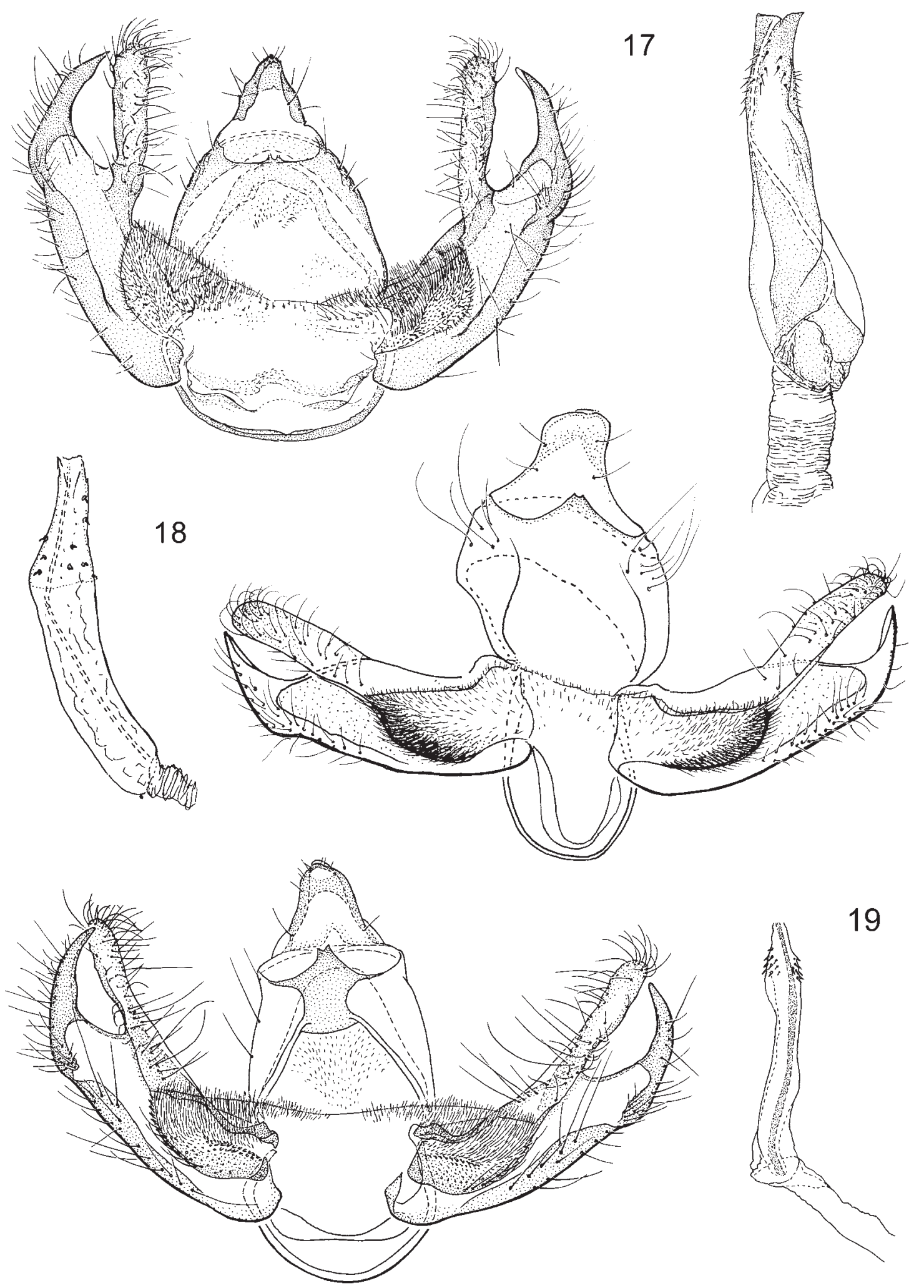

FIGURES 17-19. Male genitalia of Blastobasis. 17, B. mpala, holotype (DA slide 4137). 18, B. eridryas, lectotype (BM slide 30245). 19, B. egens, lectotype (DA slide 4740). 

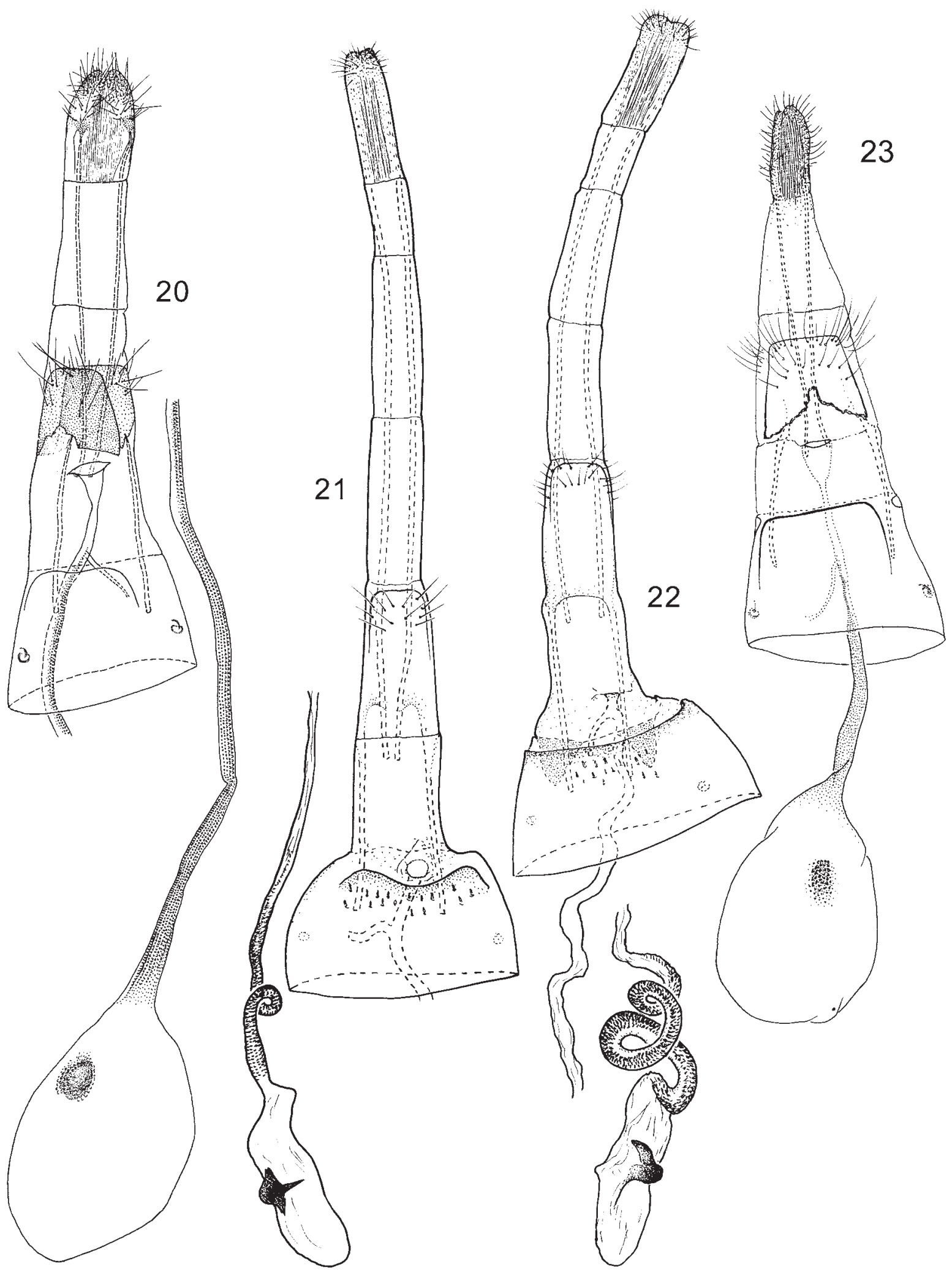

FIGURES 20-23. Female genitalia of Calosima, Neoblastobasis, and Holcocera. 20, C. arguta, paralectotype (DA slide 4629). 21, N. perisella, paratype (DA slide 5103). 22, N. ximeniaella, paratype (USNM 83367, DA slide 5104). 23, H. extensa, lectotype (DA slide 4489). 


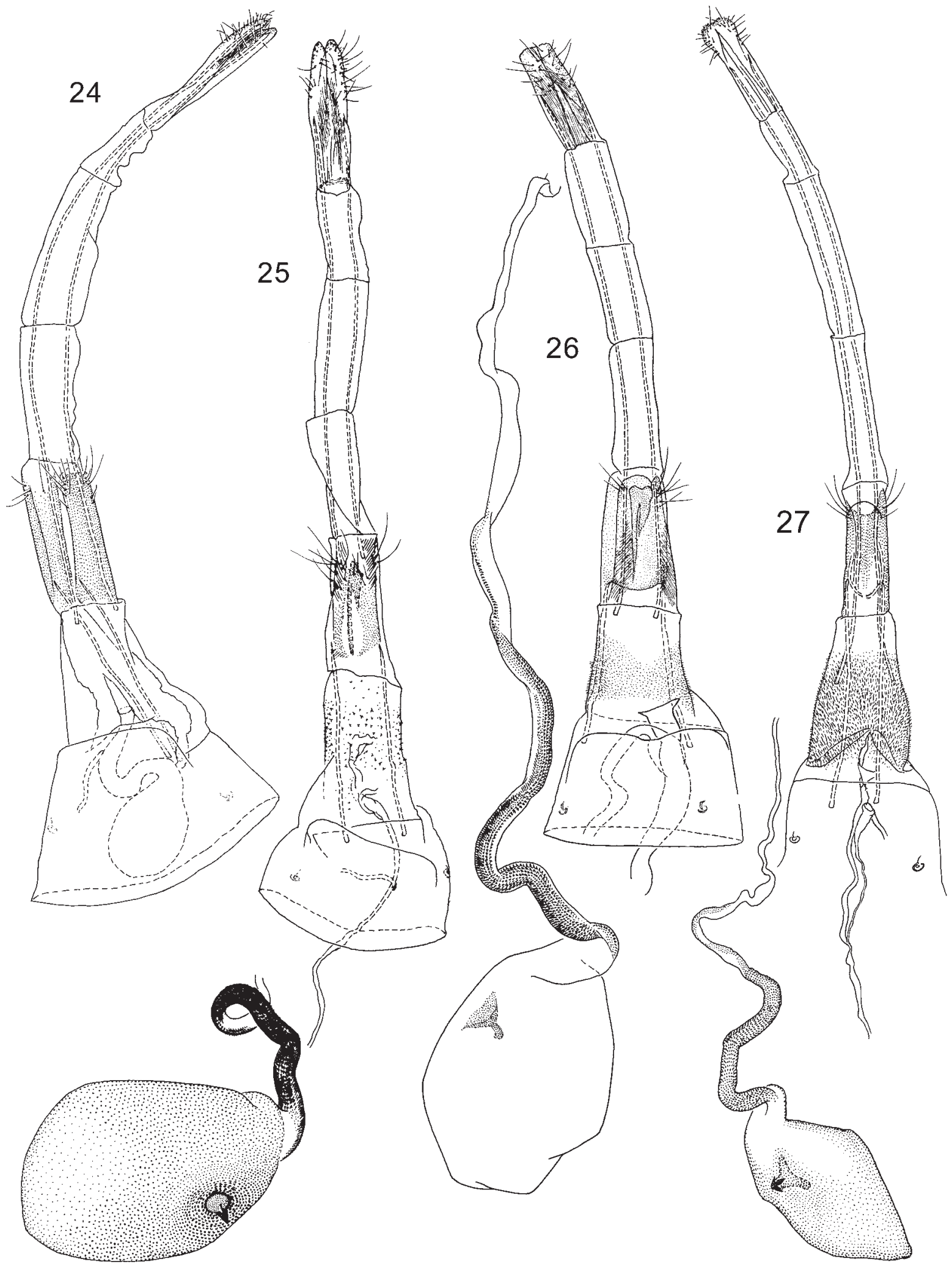

FIGURES 24-27. Female genitalia of Blastobasis. 24, B. egens paralectotype (BM slide 30241). 25, B. trachilista, lectotype (BM slide 30236). 26, B. taricheuta, holotype (DA slide 4539). 27, B. kenya, paratype (USNM 83387, DA slide 4358). 

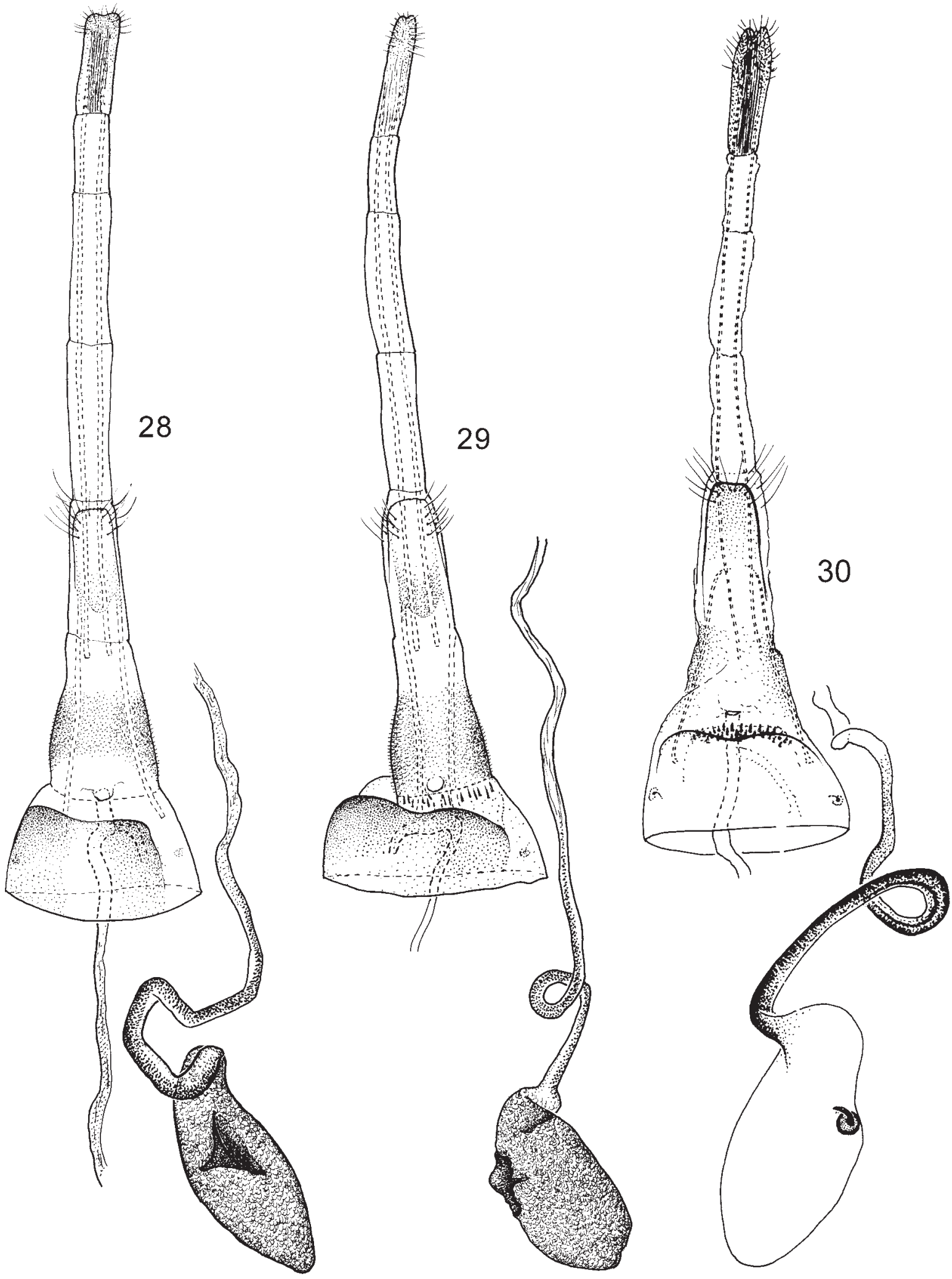

FIGURES 28-30. Female genitalia of Blastobasis. 28, B. acirfa, paratype (USNM 83402, DA slide 5110). 29, B. aynekiella, paratype (USNM 83448, DA slide 4915). 30. B. determinata, holotype (DA slide 4488). 

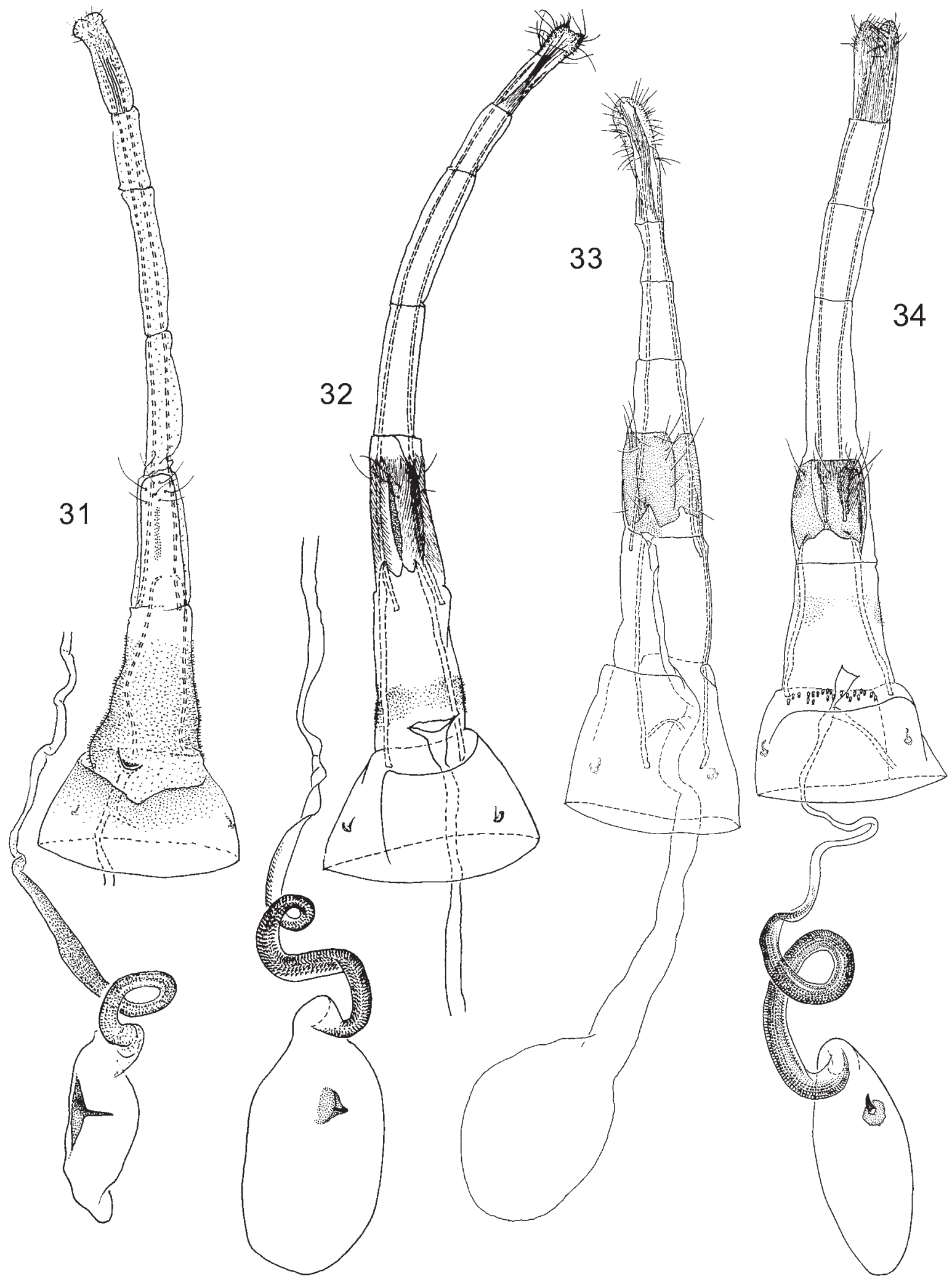

FIGURES 31-34. Female genitalia of Blastobasis and Holcocera. 31, B. glauconotata, paratype (USNM 83442, DA slide 5029). 32, B. industria, lectotype (DA slide 4737). 33, H. irroratella, holotype (BM slide 30237). 34, B. byrsodepta, lectotype (DA slide 4630). 

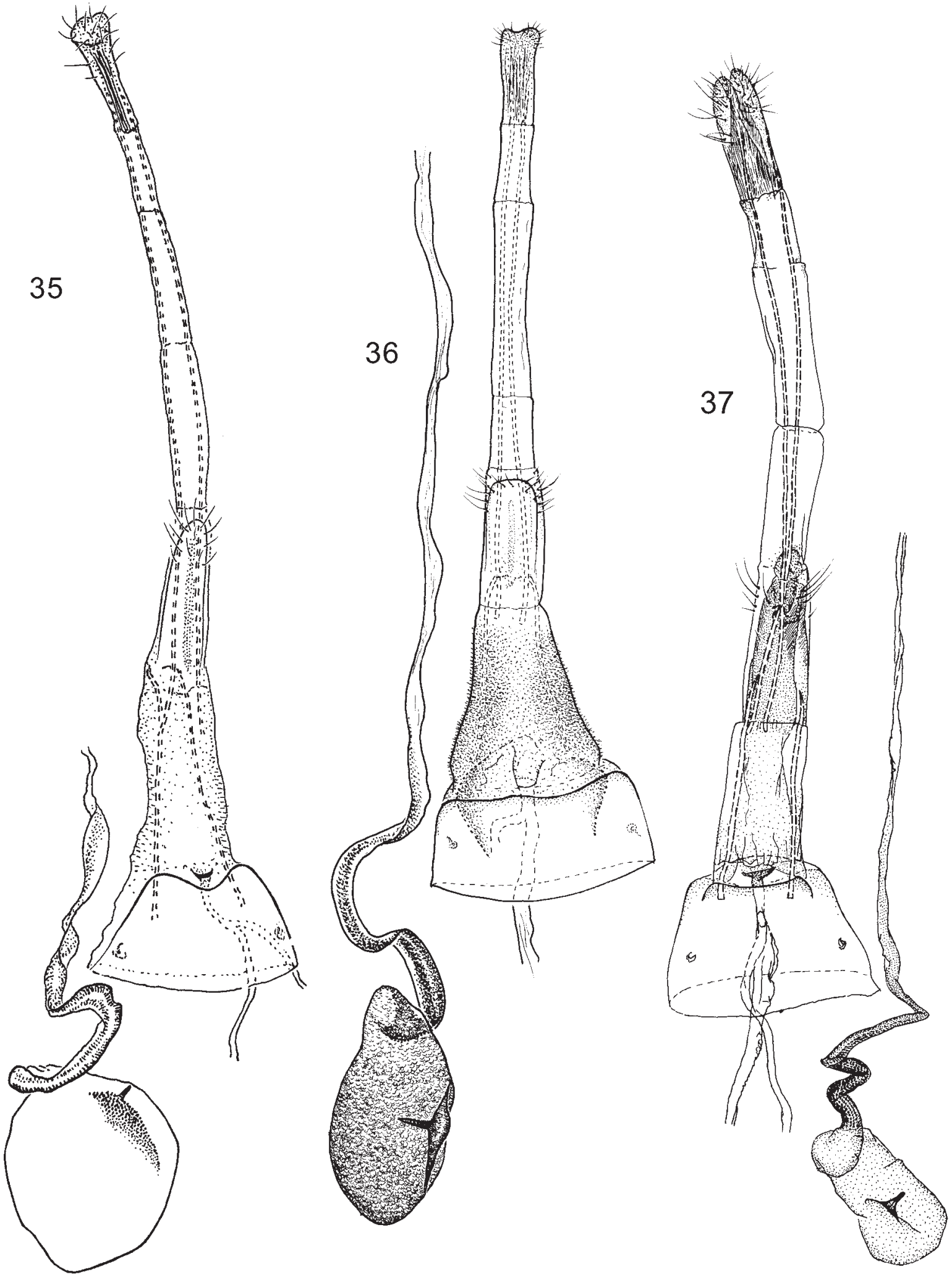

FIGURES 35-37. Female genitalia of Blastobasis. 35, B. catappaella, paratype (USNM 83412, DA slide 5072). 36, B. chuka, paratype (USNM 83431, DA slide 5094). 37, B. mpala, paratype (USNM 83408, DA slide 4138). 
FIGURES 38-49. (Opposite) Adults of Holcocera and Blastobasis. 38, B. millicentae, holotype. 39, B. industria, lectotype. 40, B. eridryas, lectotype. 41, B. determinata, holotype. 42, H. extensa, lectotype. 43, B. indigesta, lectotype. 44, B. chuka, holotype. 45, B. egens, lectotype. 46, B. glauconotata, holotype. 47, B. byrsodepta, lectotype. 48, H. irroratella, holotype. 49, B. elgonae, holotype. 
38

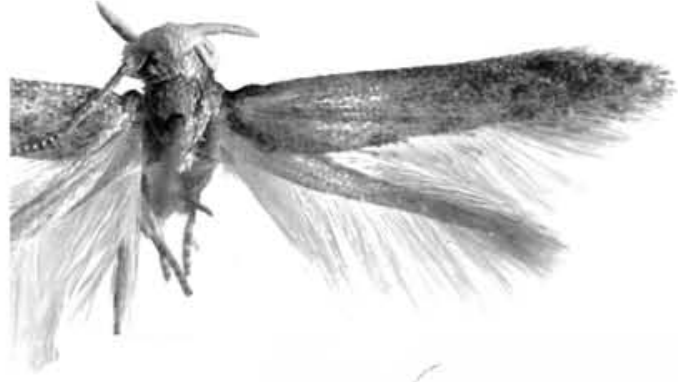

39

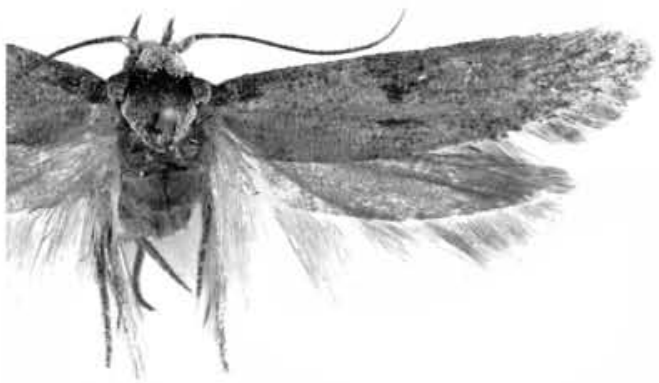

40

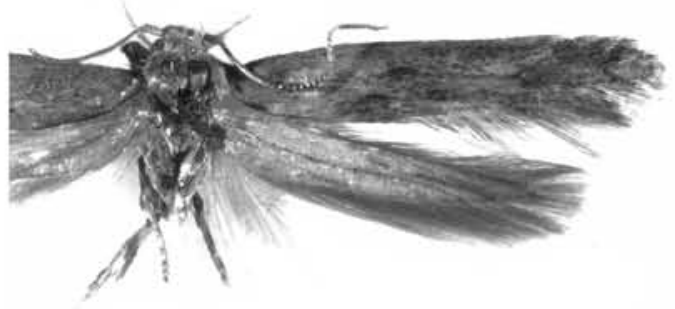

41

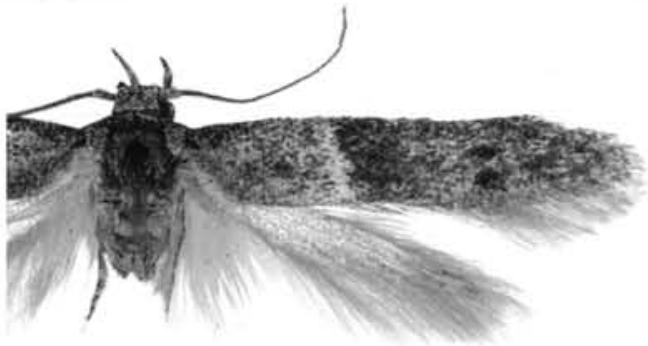

42

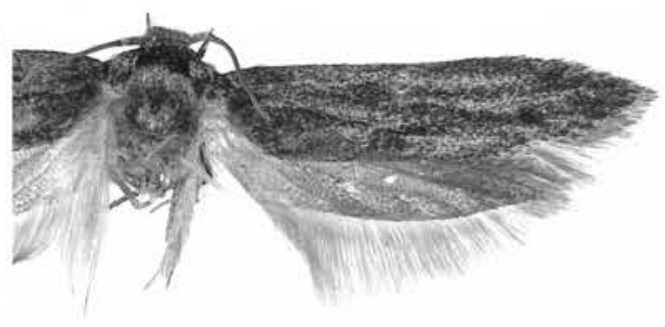

43

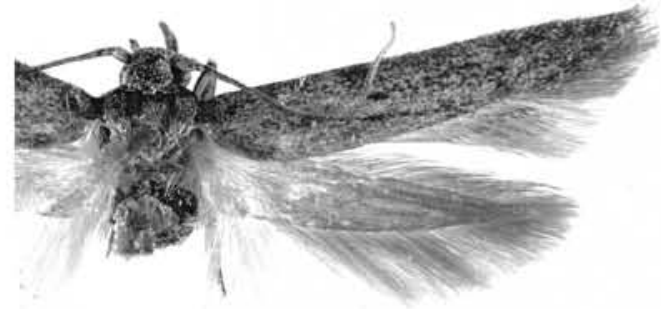

44

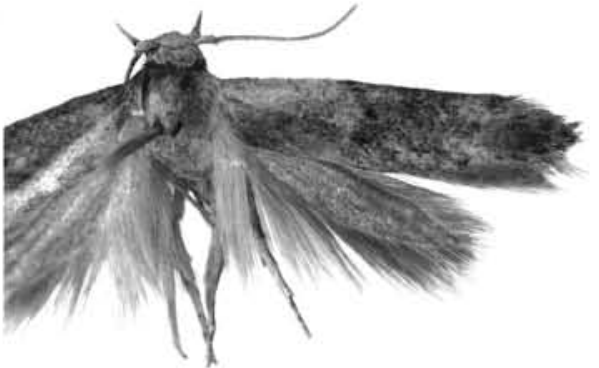

45

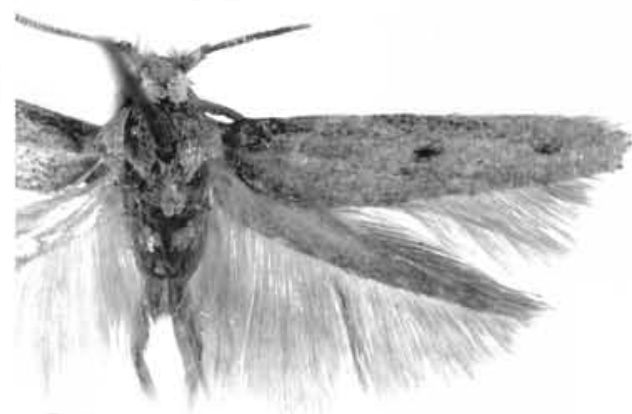

46

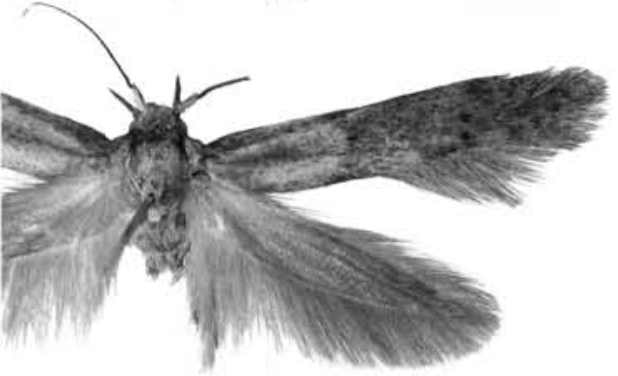

47

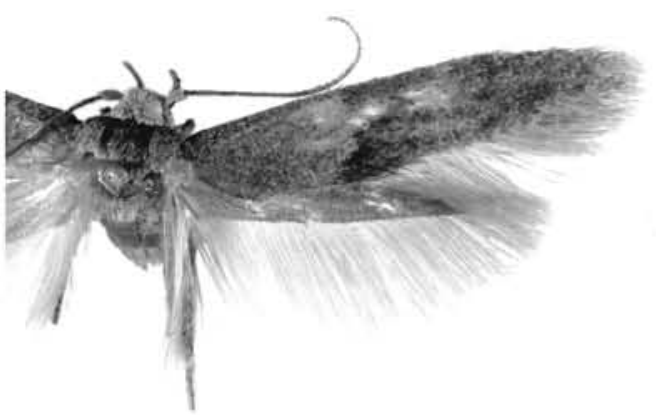

48

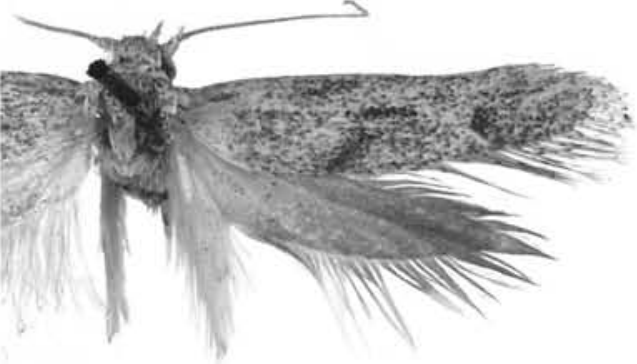

49

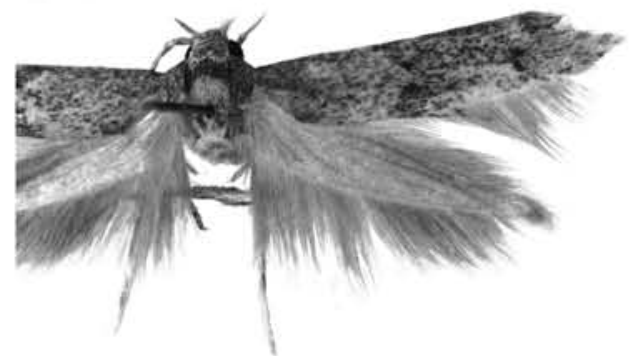



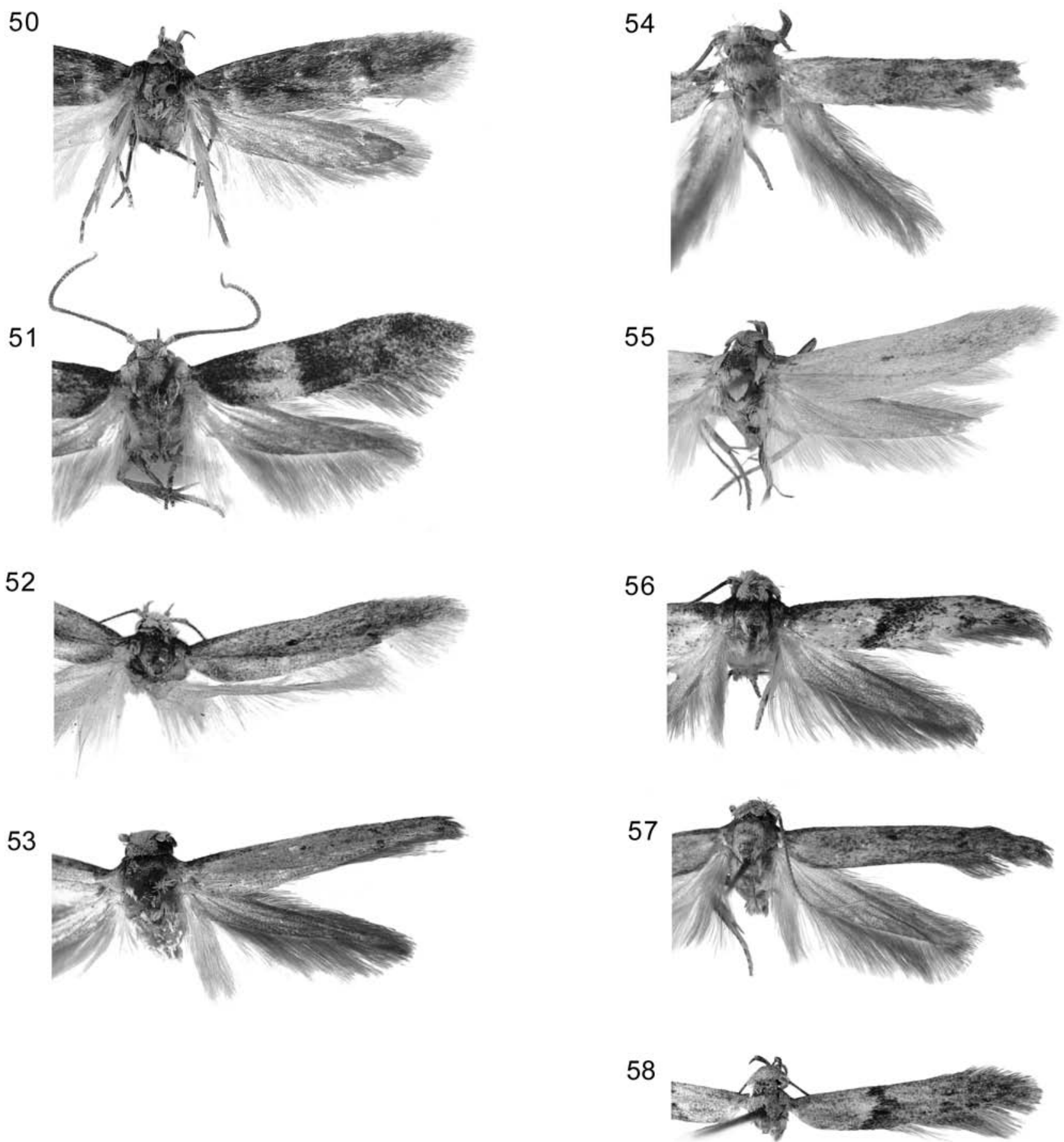

FIGURES 50-58. Adults of Blastobasis, Calosima, and Neoblastobasis. 50, B. taricheuta, holotype. 51, C. arguta, lectotype. 52, B. trachilista, lectotype. 53, N. ximeniaella, holotype. 54, N. wangithiae, holotype. 55, B. mpala, holotype. 56, B. aynekiella, holotype. 57, B. acirfa, holotype. 58 , N. laikipiae, holotype. 


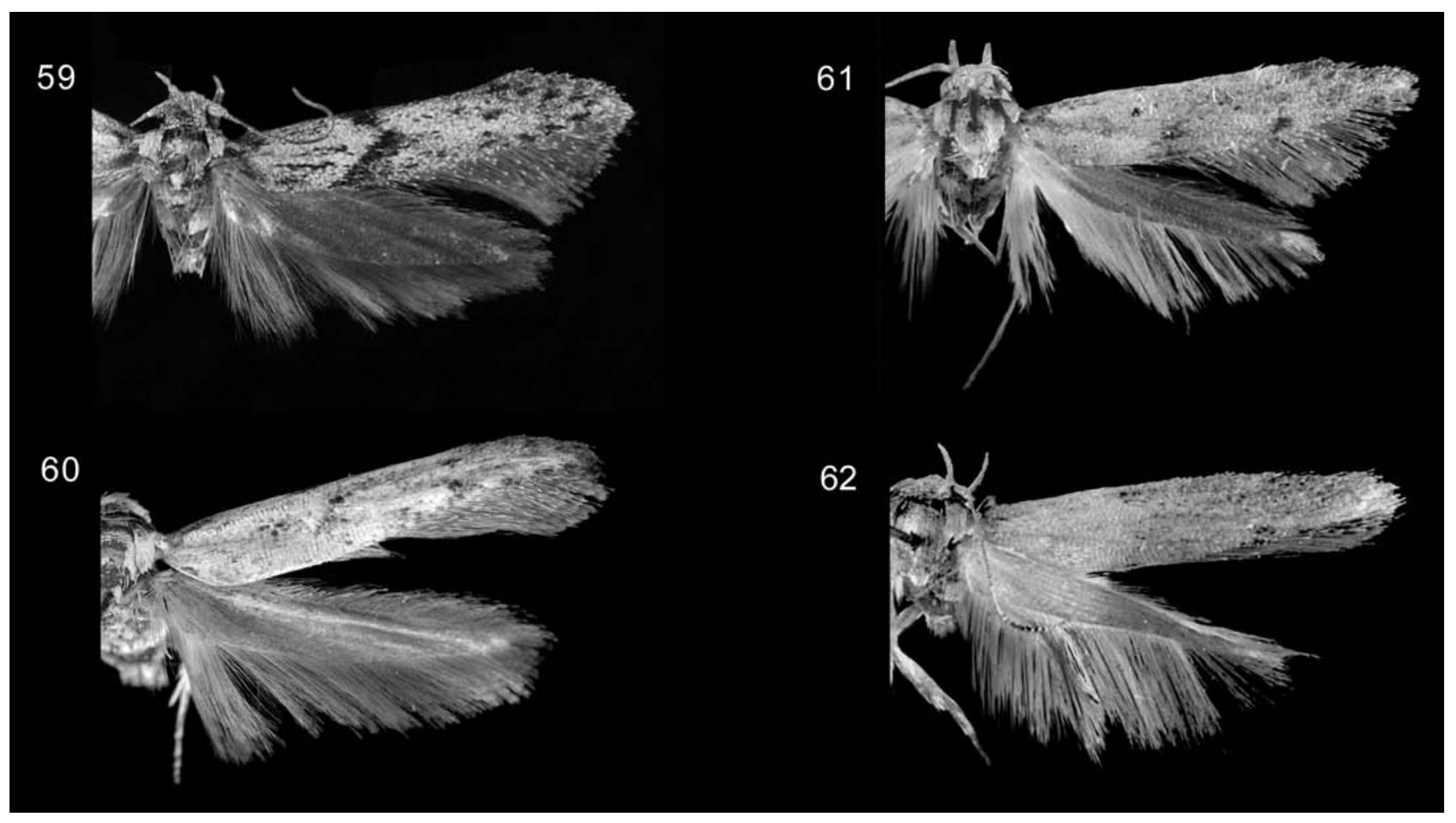

FIGURES 59-62. Adults of Blastobasis and Neoblastobasis. 59, B. catappaella, holotype. 60, B. kenya, holotype. 61, B. fatigata, lectotype. 62, N. perisella, holotype. 



\section{References}

Adamski, D. 2002. Blastobasinae of Thailand (Lepidoptera: Gelechioidea: Coleophoridae), Part I. Four new species of Calosima Dietz, 1910. Insecta Koreana, $19(3,4): 233-239$.

Adamski, D., and R. L. Brown. 1989. Morphology and Systematics of North American Blastobasidae (Lepidoptera: Gelechioidea). Mississippi Agricultural Experiment Station Technical Bulletin, 165, and Mississippi Entomological Museum, 1:1-70.

Barr, N. B., R. S. Copeland, M. De Meyer, D. Masiga, H. G. Kibogo, M. K. Billah, E. Osir, R. A. Wharton, and B. A. McPheron. 2006. Molecular Diagnostics of Economically Important Ceratitis Fruit Fly Species (Diptera: Tephritidae) in Africa Using PCR and RFLP Analyses. Bulletin of Entomological Research, 96:505-521.

Berger, P. 1989. Rainfall and Agroclimatology of the Laikipia Plateau, Kenya. Geographica Bernensia, African Study Series A7. Berne: Geographica Bernensia.

Burgess, N. D., G. P. Clarke, and W. A. Rodgers. 1998. Coastal Forest of Eastern Africa: Status, Endemism Patterns and Their Potential Causes. Biological Journal of the Linnean Society, 64:337-367.

Burns, J. M., D. H. Janzen, M. Hajibabaei, W. Hallwachs, and P. D. N. Hebert. 2007. DNA Barcodes of Closely Related (but Morphologically and Ecologically Distinct) Species of Skipper Butterflies (Hesperiidae) Can Differ by One to Three Nucleotides. Journal of the Lepidopterists' Society, 61(3):138-153.

- 2008. DNA Barcodes and Cryptic Species of Skipper Butterflies in the Genus Perichares from Area de Conservación Guanacaste, Costa Rica. Proceedings of the National Academy of Sciences of the United States of America, 105(17):6350-6355.

Chanler, W. A. 1896. Through Jungle and Desert: Travels in Eastern Africa. New York: Macmillan.

Clarke, G. P. 2000. "Climate and Climatic History." In Coastal Forests of Eastern Africa, ed. N. D. Burgess and G. P. Clarke, pp. 47-67. Gland, Switzerland: International Union for Conservation of Nature.

Clarke, J. F. G. 1941. The Preparation of Slides of the Genitalia of Lepidoptera. Bulletin of the Brooklyn Entomological Society, 36:149-161.

-1963. Catalogue of the Type-Specimens of Microlepidoptera in the British Museum (Natural History) Described by Edward Meyrick. Volume 4. London: British Museum (Natural History).

Clemens, B. 1863. American Micro-Lepidoptera. Proceedings of the Entomological Society of Philadelphia, 2:119-129.

Copeland, R. S. 2006. "Host Fruit Processing-Purpose, Tools and Methodology." In A Field Guide to the Management of Economically Important Tephritid Fruit Flies in Africa, ed. S. Ekesi and M. K. Billah, pp. F1-F11. Nairobi: ICIPE Science Press. 
Copeland, R. S., W. Okeka, A. Friedberg, B. Merz, I. M. White, M. De Meyer, and Q. Luke. 2005. Fruit Flies (Diptera, Tephritidae) of Kakamega Forest, Kenya. Journal of East African Natural History, 94:247-278.

Copeland, R. S., and R. A. Wharton. 2006. Year-Round Production of Pest Ceratitis Species (Diptera: Tephritidae) in Fruit of the Invasive Species Solanum mauritianum in Kenya. Annals of the Entomological Society of America, 99(3):530-535.

Copeland, R. S., R. A. Wharton, Q. Luke, and M. De Meyer. 2002. Indigenous Hosts of Ceratitis capitata (Diptera: Tephritidae) in Kenya. Annals of the Entomological Society of America, 95(6):672-694.

Copeland, R. S., R. A. Wharton, Q. Luke, M. De Meyer, S. Lux, N. Zenz, P. Machera, and M. Okumu. 2006. Geographic Distribution, Host Fruit, and Parasitoids of African Fruit Fly Pests Ceratitis anonae, Ceratitis cosyra, Ceratitis fasciventris, and Ceratitis rosa (Diptera: Tephritidae) in Kenya. Annals of the Entomological Society of America, 99(2):261278.

Copeland, R. S., R. A. Wharton, and Q. Luke. 2009. A Natural History of the Wild Fruits of Kenya. CD-ROM. Journal of East African Natural History, 98(1):11-66.

Copeland, R. S., I. M. White, M. Okumu, P. Machera, and R. A. Wharton. 2004. "Insects Associated with Fruits of the Oleaceae (Asteridae, Lamiales) in Kenya, with Special Reference to the Tephritidae (Diptera)." In D. Elmo Hardy Memorial Volume: Contribution to the Systematics and Evolution of Diptera, ed. N. L. Evenhuis and K. Y. Kaneshiro, pp. 135164. Bishop Museum Bulletin in Entomology, No. 12. Honolulu: Bishop Museum Press.

Delvare, G., and H.-P. Aberlenc. 1989. Les insectes d'Afrique de d'Amerique tropical cles pour la reconnaissance des families. Montpellier, France: CIRAD.

De Meyer, M., R. S. Copeland, S. A. Lux, M. Mansell, S. Quilici, R. Wharton, I. M. White, and N. Zenz. 2002. Annotated Checklist of Host Plants for Afrotropical Fruit Flies (Diptera: Tephritidae) of the Genus Ceratitis. Documentation Zoologiques, Musée Royal de L'Afrique Centrale, Tervuren Belgique, 27:1-9.

De Meyer, M., and A. Freidberg. 2006. "Revision of the Subgenus Ceratitis (Pterandrus) Bezzi (Diptera: Tephritidae).” In Biotaxonomy of Tephritoidea, ed. A. Freidberg. Israel Journal of Entomology, 35-36:197-315.

DeSalle, R. 2007. Phenetic and DNA Taxonomy; a Comment on Waugh. BioEssays, 29(12):1289-1290.

Dietz, W. G. 1910. Revision of the Blastobasidae of North America. Transactions of the American Entomological Society, 36:1-72.

Gallmann, K. 1991. I Dreamed of Africa. New York: Viking.

Ghesquière, J. 1940. Catalogue Raisonnés de la Faune Entomologique du Congo Belge, Lépidoptères, Microlépidoptères (Première partie), 1-120 pp, Plates I - V.

Gozmány, L. A., and L. Váry. 1973. The Tineidae of the Ethiopian Region. Pretoria, South Africa: Transvaal Museum.

Grant, L. 1995. Nyamuluki: A Small Piece of Africa. Cambridge: Silent Books.

- 2001. On a Kenya Ranch. Perthshire, UK: Pioneer Associates.
Greenway, P. J. 1973. A Classification of the Vegetation of East Africa. Kirkia, 9:1-68.

Gregory, J. W. 1896. The Great Rift Valley; Being the Narrative of a Journey to Mount Kenya and Lake Baringo, with Some Account of the Geology, Natural History, Anthropology and Future Prospects of British East Africa. London: J. Murray.

Hajibabaei, M., D. H. Janzen, J. M. Burns, W. Hallwachs, and P. D. N. Hebert. 2006. DNA Barcodes Distinguish Species of Tropical Lepidoptera. Proceedings of the National Academy of Sciences of the United States of America, 103(4):968-971.

Hajibabaei, M., G. A. Singer, P. D. N. Hebert, and D. D. Hickey. 2007. DNA Barcoding: How It Complements Taxonomy, Molecular Phylogenetics and Population Genetics. Trends in Genetics, 23(4):167-172.

Hargraves, E. 1930 [1929]. Report on the Entomology Section. Annual Report, pp. 20-22. Freetown, Sierra Leone: Lands and Forests Department.

Hebert, P. D. N., A. Cywinsky, S. L. Ball, and J. R. deWaard. 2003. Biological Identifications through DNA Barcodes. Proceedings of the Royal Society of London B, 270(1511):313-321.

Hebert, P. D. N., E. H. Penton, J. M. Burns, D. H. Janzen, and W. Hallwachs. 2004. Ten Species in One: DNA Barcoding Reveals Cryptic Species in the Neotropical Skipper Butterfly Astraptes fulgerator. Proceedings of the National Academy of Sciences of the Untied States of America. 101(41):14,81214,817 .

Hodges, R. W. 1998. "Gelechioidea." In Handbuch der Zoologie, Volume 4, Arthropoda: Insecta, Part 35, Lepidoptera, Moths and Butterflies, Volume 1, Evolution, Systematics, and Biogeography. ed. N. P. Kristensen, pp. 131-158. Berlin: Walter de Gruyter.

Holloway, J. D., J. D. Bradley, and D. J. Carter. 1987. CIE guides to the insects of importance to man. 1. Lepidoptera. Wallingford, Oxon, UK: CAB International.

Janse, A. J. T. 1917. Check-List of the South African Lepidoptera, Heterocera. Pretoria, South Africa: Buckley and Van Duyn. . 1932-1964. The Moths of South Africa. Volumes 1-7. Pretoria, South Africa: Transvaal Museum.

-1968. On the Types of Southern African Microlepidoptera Described by the Late Edward Meyrick and Preserved in the Transvaal Museum, Volume 1, Tineidae. Transvaal Museum Memoir, No. 16. Pretoria, South Africa: Transvaal Museum.

Keesing, F. 1998. Impacts of Ungulates on the Demography and Diversity of Small Mammals in Central Kenya. Oecologia, 116:381-389.

- 2000. Cryptic Consumers and the Ecology of an African Savanna. BioScience, 50:205-215.

Kornerup, A., and J. H. Wanscher. 1978. Methuen Handbook of Colour. 2nd ed. London: Methuen.

Kuznetzov, V. I., and S. Y. Sinev. 1985. Neoblastobasis, a New Genus of Blastobasidae (Lepidoptera) from the USSR. Zoologicheskii Zhurnal, 64(4):529-537. [In Russian with an English summary.]

Le Pelley, R. H. 1930 [1931]. On the Pest-Status of Certain Coffee-Feeding Insects, with Records Newly Recorded from 
Coffee in Kenya. Journal of the East Africa and Uganda Natural History Society, 40-41:67-77.

Lovett, J. C. 1993. "Eastern Arc Moist Forest Flora." In Biogeography and Ecology of the Rain Forests of Eastern Africa, ed. J. C. Lovett and S. K. Wasser, pp. 33-55. Cambridge: Cambridge University Press.

Medler, J. T. 1980. Insects of Nigeria-Check List and Bibliography. Memoirs of the American Entomological Institute, No. 30. Gainesville, Fla.: American Entomological Institute.

Meyrick, E. 1894. On a Collection of Lepidoptera from Upper Burma. Transactions of the Entomological Society of London, 1894:1-29.

-1909. New South African Micro-Lepidoptera. Annals of the South African Museum, 5:349-379.

- 1913. Descriptions of South African Micro-Lepidoptera. Annals of the Transvaal Museum, 3:267-336.

-1914a. Descriptions of South African Micro-Lepidoptera. Annals of the Transvaal Museum, 4:187-205.

-. 1914b. Exotic Microlepidoptera. Volume 1. London: Taylor and Francis.

- 1918. Descriptions of South African Micro-Lepidoptera. Annals of the Transvaal Museum, 6:1-59.

-1921. Descriptions of South African Micro-Lepidoptera. Annals of the Transvaal Museum, 8:4-148.

- 1931. Exotic Microlepidoptera. Volume 4. London: Taylor and Francis.

-. 1932. Entomological Expedition to Abyssinia, 1926-7. Microlepidoptera. Transactions of the Entomological Society of London, 80:107-120.

Miller, S. E. 2000. "Biodiversity Studies at Mpala Research Centre." In 1998-1999 ICIPE Annual Scientific Report, ed. A. Ng'eny-Mengech, pp. 166-167. Nairobi: International Centre of Insect Physiology and Ecology.

Miller, S. E., and J. D. Lazell. 2003 [2001]. A Herpetological Reconnaissance of Mpala Research Centre, Laikipia, Kenya. Journal of East African Natural History, 90:103-107.

Miller, S. E., and L. M. Rogo. 2002 [2001]. Challenges and Opportunities in Understanding and Utilization of African Insect Diversity. Cimbebasia, 17:197-218.

Nonveiller, G. 1984. Catalogue cemmenté et illustré des insects du cameroun d'intérêt agricole. Mémoires, No. 15. Belgrade: Institut pour la Protection des Plantes.

Park, Kyu Tek. 1984. Description of two species of Blastobasidae (Lepidoptera) from Korea. Korean Journal of Plant Protection, 23:56-60.

Pinhey, E. C. G. 1975. Moths of Southern Africa: Descriptions and Colour Illustrations of 1183 Species. Cape Town, South Africa: Tafelberg.
Ratnasingham, S., and P. D. N. Hebert. 2007. BOLD: The Barcoding of Life Data System (http://www.barcodinglife.org). Molecular Ecology Notes, 7(3):355-364.

Rehn, J. A. G. 1936. Zoological Results of the George Vanderbilt African Expedition of 1934. Part I-Introduction and Itinerary. Proceedings of the Academy of Natural Sciences of Philadelphia, 88:1-14.

Rungs, C. E. E. 1979. Catalogue raisonné des Lépidoptères du Maroc. 1. Travaux de l'Institute Scientifique, Zoology, 39:1-222.

Scholtz, C. H., and E. Holm, eds. 1985. Insects of Southern Africa. Durban, South Africa: Butterworths.

Sinev, S. Y. 2004. Agonoxenidae, Batrachedridae, Blastobasidae, Chrysopeleiidae, Cosmopterigidae, and Stathmopodidae (Lepidoptera: Gelechioidea). Esperiana Memoir, 1:107-130.

Tamura, K., J. Dudley, M. Nei, and S. Kumar. 2007. MEGA4: Molecular Evolutionary Genetics Analysis (MEGA) Software Version 4.0. Molecular Biology and Evolution, 24:1596-1599.

von Höhnel, L. 1894. Discovery of Lakes Rudolf and Stefanie: A Narrative of Count Samuel Teleki's Exploring \& Hunting Expedition in Eastern Equatorial Africa in 1887 \& 1888, by His Companion Lieut. Ludwig von Höhnel. Trans. N. Bell (N. D'Anvers). London: Longmans, Green.

Waugh, J., L. Huynen, C. Millar, and D. Lambert. 2008. DNA Barcoding of Animal Species-Response to DeSalle. BioEssays, 30(1):92-93.

Walsingham, Lord (Thomas de Gray). 1891. African MicroLepidoptera. Transactions of the Entomological Society of London, 1891:63-132.

— 1907. Descriptions of New North American Tineid Moths, with a Generic Table of the Family Blastobasidae. Proceedings of the United States National Museum, 33:197-228.

White, I. M., R. S. Copeland, and D. L. Hancock. 2003. Revision of the Afrotropical Genus Trirhithrum Bezzi (Diptera: Tephritidae). Cimbebasia, 18:71-137.

Young, T. P., N. Patridge, and A. Macrae. 1995. Long-Term Glades in Acacia Bushland and Their Edge Effects in Laikipia, Kenya. Ecological Applications, 5:97-108.

Young, T. P., C. H. Stubblefield, and L. A. Isbell. 1977. Ants on Swollen-Thorn Acacias: Species Coexistence in a Simple System. Oecologia, 109:98-107.

Zeller, P. C. 1839. Versuch einer naturgemassen Eintheilung der Schaben, Tineina. Isis, von Oken 23(3):167-220.

- 1855. Die Arten der Gattung Butalis beschreiben. Linnaea Entomologica, 10:169-269.

Zhang, B. C. 1994. Index of Economically Important Lepidoptera. Cambridge: Cambridge University Press. 



\section{Index of Insect Names}

Page numbers in bold italic font indicate the start of the taxonomic account.

Blastobasidae, 1

Blastobasinae, 1, 5, 9, 40

Blastobasini, 9

Blastobasis, 14, 36, 40, 43, 44

acirfa , 4, 5, 6, 17, 20, 21-23, 25, 40-42, 43, 48, 53, 58

aynekiella, 4, 5, 6, 17, 20, 23, 24, 25, 40-42, 43, 48, 53, 58

biceratala, 9

byrsodepta, 6, 38, 39, 54, 57

catappaella, 4, 5, 6, 25, 26, 40-42, 43, 48, 55, 59

chuka , 3, 4, 5, 6, 23, 25, 29, 30, 31, 40-42, 43, 44, 49, 55, 57

determinata, 6, 38, 53, 57

egens, 5, 6, 34, 36, 50, 52, 57

elgonae, 3, 4, 5, 31, 32, 33, 40-42, 43, 44, 49, 57

eridryas, $5,33,50,57$

fatigata, 5, 36, 46, 59

glauconotata, 3, 4, 5, 6, 25, 28, 29, 40-42, 43, 44, 49, 54, 57

indigesta, 5, 31, 33, 40, 47, 57

industria, 6, 39, 54, 57

kenya, 3, 4, 5, 6, 17, 19, 20, 23, 25, 40-42, 43, 44, 47, 52, 59

millicentae, 4, 5, 15, 16, 40-42, 43, 44, 47, 57

mpala, 4, 5, 6, 34, 35, 36, 43, 50, 55, 58

taricheuta, 6, 37, 52, 58

trachilista, 6, 37, 52, 58

Calosima, 8

albafaciella, 8

arguta, 5, 6, 8, 9, 45, 51, 58

argyrosplendella, 8

Ceratitis, 40

capitata, 40

Coleophoridae, 2, 5

Holcocera, 6

chalcofrontella, 6

extensa, 6, 7, 8, 51, 57 
Holcocera (continued) irroratella, 5, 7, 54, 57 lignyodes, 6, 7

Holcocerini, 6

Neoblastobasis, 9, 14, 40, 43, 44 laikipiae, 4, 5, 9, 10, 11, 43, 45, 58 perisella, 4, 5, 6, 11, 13, 14, 40-42, 43, 46, 51, 59 wangithiae, 4, 5, 9, 11, 12, 40-42, 43, 45, 58 ximeniaella, 4, 5, 6, 11, 14, 15, 40-42, 43, 46, 51, 58

Oecophora (Scythris), 14 phycidella, 14

Syndroma, 6
Tecmerium, 7, 8 Tephritidae, 1, 40 Thaumatotibia, 40 leucotreta, 40 Tortricidae, 40

Zenodochium, 8, 9 


\section{Index of Plant Names}

Acacia, 2

Achariaceae, 29, 31, 41

Adenia sp., 18, 20, 42

Afrocarpus falcatus, 27, 29, 42

Allophylus abyssinicus, 31, 42

Annonaceae, 20, 41

Apocynaceae, 11, 20, 31, 41

Arachis hypogaea, 39

Araliaceae, 29, 41

Arecaceae, 39

Balanitaceae, 41

Balanites, 2

Balanites manghamii acuta, 41

Borassus aethiopum, 39

Boscia, 2

Calophyllum inophyllum, 14, 18, 20, 41

Canellaceae, 29, 41

Celastraceae, 20, 29, 41

Chaetacme aristata, 27, 29, 42

Chrysobalanaceae, 20, 41

Chrysophyllum

albidum, 23, 24, 42

gorungosanum, 30, 31, 42

viridifolium, 18, 20, 42

Clusiaceae, 14, 20, 31, 41

Cola minor, 18, 20, 42

Combretaceae, 20, 25, 41

Connaraceae, 20, 41

Cussonia spicata, 29, 41

Deinbollia borbonica, 18, 20, 42

Dictyophleba lucida, 31, 41

Diospyros

kabuyeana, 18, 20, 41

sp., 20, 41

Diphasia sp., 18, 20, 31, 42 
Dovyalis macrocalyx, 20, 42

Dracaena mannii, 18, 20, 41

Dracaenaceae, 20, 41

Drypetes

gerrardii, 27, 29, 31, 41

natalensis var. leiogyna, 41

Ebenaceae, 20, 41

Ekebergia capensis, 27, 29, 41

Elaeodendron buchananii, 27, 29, 41

Euphorbiaceae, 29, 31, 41

Fabaceae, 39

Flacourtia indica, 17, 20, 31, 42

Garcinia volkensii, 31, 41

Hirtella zanzibarica, 17, 18, 20, 22, 41

Hugonia castaneifolia, 14, 41

Inhambanella henriquezii, 18, 20, 42

Landolphia

buchananii, 31, 41

sp., 18, 20, 41

Lecaniodiscus fraxinifolius scassellatii, 20, 42

Lepisanthes senegalensis, 20, 42

Linaceae, 14, 41

Loganiaceae, 20, 29, 41

Ludia mauritiana, 18, 20, 42

\section{Manilkara}

butugi, 21, 23, 42

sansibarensis, 18, 20, 42

Meliaceae, 29, 41
Menispermaceae, 23, 25, 41

Mimusops

aedificatoria, 18, 20, 22, 42

bagshawei, 21, 23, 24, 42

kummel, 27, 29, 42

Moraceae, 20, 41

Olacaceae, 20, 21, 23, 25, 29, 41

Olea

welwitschii, 21, 23, 25, 41

woodiana disjuncta, 18, 20, 21, 23, 41

Oxyanthus goetzei keniensis, 18, 20, 40,42

Passiflora mollissima, 2, 31, 42

Passifloraceae, 20, 31, 42

Pleiocarpa pycnantha, 11, 40, 41

Podocarpaceae, 29, 31, 42

Podocarpus latifolius, 31, 42

Prunus africana, 21, 23, 25, 27, 29, 31, 42

Rawsonia lucida, 29, 31, 41

Rosaceae, 23, 25, 31, 42

Rourea minor, 18, 20, 41

Rubiaceae, 20, 29, 40, 42

Rutaceae, 20, 29, 31, 33, 42

Saba comorensis, 20, 41

Salacia

elegans, 20, 41

sp., 20

Salicaceae, 20, 31, 42

Sapindaceae, 20, 31, 42

Sapotaceae, 20, 23, 24, 29, 31, 42
Schrebera alata, 27, 29, 41

Shirakiopsis elliptica, 41

Solanaceae, 29, 42

Solanum anguivi, 29, 42

Sterculiaceae, 20, 42

Strychnos

madagascariensis form e, 20, 41

mitis, 28, 29, 41

sp., 20

Synaptolepis alternifolia, 42

Synsepalum cerasiferum, 21, 23, 42

Terminalia catappa, 18, 20, 25, 41

Thymelaeaceae, 42

Tiliacora funifera, 21, 23, 25, 41

Toddalia asiatica, 18, 20, 27, 29, 42

Trichilia emetica, 20, 41

Trilepisium madagascariense, 18, 20, 41

Ulmaceae, 29, 42

Vepris

nobilis, 18, 20, 29, 33, 42

simplicifolia, 27, 29, 30, 31, 42

trichocarpa, 27, 29, 42

Warburgia ugandensis, 27, 29, 41

Ximenia caffra, 14, 18, 20, 41

Xylopia parviflora, 18

sp., 20, 41

Zingiber officinale, 39

Zingiberaceae, 39 


\section{REQUIREMENTS FOR SMITHSONIAN SERIES PUBLICATION}

ALL MANUSCRIPTS ARE REVIEWED FOR ADHERENCE TO THE SISP MANUSCRIPT PREPARATION AND STYLE GUIDE FOR AUTHORS (available on the "Submissions" page at www.scholarlypress.si.edu). Manuscripts not in compliance will be returned to the author. Manuscripts intended for publication in the Contributions Series are evaluated by a content review board and undergo substantive peer review. Accepted manuscripts are submitted for funding approval and scheduling to the Publications Oversight Board.

MINIMUM MANUSCRIPT LENGTH is thirty manuscript pages. If a manuscript is longer than average, an appropriate length will be determined during peer review and evaluation by the Content Review Board. Authors may be asked to edit manuscripts that are determined to be too long.

TEXT must be prepared in a recent version of Microsoft Word; use a Times font in 12 point for regular text; be double spaced; and have 1" margins. Each chapter/section must be saved in a separate file.

REQUIRED ELEMENTS are title page, abstract page, table of contents, main text, and reference section. See the SISP Manuscript Preparation and Style Guide for Authors for the order of all elements.

HEADINGS should be styled so different levels of headings are distinct from each other and so the organization of the manuscript is clear. Insert one line space above and one line space below all headings.

FRONT MATTER should include title page, abstract page, and table of contents. All other sections are optional. Abstracts must not exceed 300 words. Table of contents should include A-, B-, and C-level headings.

TABLES (numbered, with captions, stubs, rules) should be submitted in separate MS Word files; should include footnotes, if appropriate; should have rules only at top, bottom, and beneath column heads. Print outs of each table should accompany the manuscript to ensure correct layout of data. Tabulations within running text should not be numbered or formatted like formal tables, and should be included in the text of the manuscript.

FIGURE CAPTIONS should be provided in a separate MS Word file.

FIGURES (e.g., photographs, line art, maps) should be numbered sequentially $(1,2,3$, etc.) in the order called out; be placed throughout text, not at end of manuscript; have all components of composites lettered with lowercase letters and described in the caption; include a scale bar or scale description, if appropriate; include any legends in or on the figure rather than in a caption.
ART must not be embedded in the main text.

Figures must be original and submitted as individual TIFF or EPS files. Resolution for art files must be at least $300 \mathrm{dpi}$ for grayscale and color images and at least $1200 \mathrm{dpi}$ for line art. Electronic images should measure no more than 100\% and no less than $75 \%$ of final size when published. JPG files will not be accepted. Color images significantly increase costs so should be included only if required. Funding for color art is subject to approval by SISP and the Publications Oversight Board.

TAXONOMIC KEYS in natural history papers should use the aligned-couplet form for zoology. If cross referencing is required between key and text, do not include page references within the key but number the keyed-out taxa, using the same numbers with their corresponding heads in the text.

SYNONOMY IN ZOOLOGY must use the short form (taxon, author, year:page), with full reference at the end of the paper under "References."

IN-TEXT REFERENCES should be used rather than bibliographic notes and should follow the author-date system in the following format: "(author last name, year)" or ". . . author (year)"; "(author, year:page used within the text)" or “.. . author (year:page)." A full citation should be included in a "References" section.

ENDNOTES are to be used in lieu of footnotes and should be keyed manually into a separate MS Word file, in a section titled "Notes". Notes should not contain bibliographic information. Manually type superscript numerals in text and use full-sized numerals at the beginning of each note in the "Notes" section. SISP will determine the best placement of the notes section, either at the end of each chapter or at the end of the main text.

REFERENCES should be in alphabetical order, and in chronological order for same-author entries. Each reference should be cited at least once in main text. Complete bibliographic information must be included in all citations (e.g., author/editor, title, subtitle, edition, volume, issue, pages, figures). For books, place of publication and publisher are required. For journals, use the parentheses system for volume(number):pagination [e.g., "10(2):5-9"]. Do not use "et al."; all authors/ editors should be included in reference citations. In titles, capitalize first word, last word, first word after colon, and all other words except articles, conjunctions, and prepositions. Examples of the most common types of citations are provided in the SISP Manuscript Preparation and Author Style Guide.

For questions regarding the guidelines, please email SISP at schol.press@si.edu. 